\title{
PEDAGOGICAL SCIENCE IN THE XXI CENTURY: STATE AND DEVELOPMENT TRENDS
}

Collective monograph

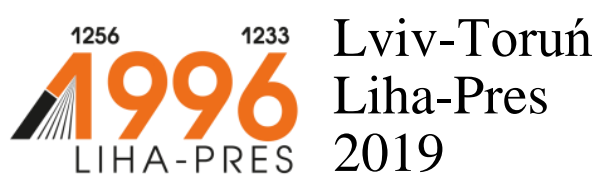




\section{Reviewers:}

Prof. nadzw., dr hab. Stanistaw Kunikowski, Rektor of Cuiavian University in Wloclawek (Republic of Poland);

Prof. $d r$ hab. Kazimierz Pierzchata, Katolicki Uniwersytet Lubelski/Catholic University of Lublin (Republic of Poland);

Prof. dr hab. Stanisław Juszczyk, Uniwersytet Ślaski / University of Silesia (Republic of Poland).

Pedagogical science in the XXI century: state and development trends : collective monograph / Jan Grzesiak, M. V. Pahuta, I. O. Stashevska, L. O. Sushchenko. Lviv-Toruń : Liha-Pres, 2019. - 160 p.

ISBN 978-966-397-129-2

Liha-Pres is an international publishing house which belongs to the category „C” according to the classification of Research School for Socio-Economic and Natural SENSE Sciences of the Environment (SENSE) [isn: 3943, 1705, 1704, 1703, 1702, 1701; prefixMetCode: 978966397]. Official website - www.sense.nl. 


\section{CONTENTS}

SCIENTIFIC AND METHODOLOGICAL ASPECTS

OF IMPROVING THE QUALITY OF HUMANISTIC

EDUCATION IN THE ERA OF TRANSFORMATION

Grzesiak Jan

1

EDUCATIONAL IDEAL IN THE PEDAGOGICAL WORKS

OF WESTERN UKRAINE IN THE INTERWAR PERIOD

Nevmerzhytska 0 . . .26

PRECONDITIONS AND PRIORITY DIRECTIONS

OF THE REFORM OF THE SYSTEM

IN NATIONAL HIGHER EDUCATION

Orshanskiy L.V. . .49

AXIOLOGICAL ESTABLISHMENT

OF A FUTURE SPECIALIST IN THE PROCESS

OF PROFESSIONAL EDUCATION

Pahuta M. V. . .71 
LEADING METHODOLOGICAL APPROACHES

AND METHODS OF SCIENTIFIC KNOWLEDGE

IN THE SPHERE OF COMPARATIVE MUSIC PEDAGOGY

Stashevska I. O.

THE STIMULATION OF PROFESSIONAL SELF-IMPROVEMENT

OF PRIMARY SCHOOL TEACHERS IN THE POSTGRADUATE

EDUCATION SYSTEM: TARGET-SETTING

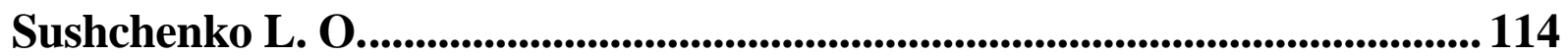

PEDAGOGICAL RESOURCE OF FORMATION

OF PROJECT TECHNOLOGICAL CULTURE

FOR TEACHERS OF TECHNOLOGY

Slabko V. M., Makarenko L. L. 134 


\section{SCIENTIFIC AND METHODOLOGICAL ASPECTS OF IMPROVING THE QUALITY OF HUMANISTIC EDUCATION IN THE ERA OF TRANSFORMATION}

\section{Grzesiak Jan}

\section{INTRODUCTION}

Adjusting education to the standards of the knowledge society, which requires innovation and evaluation in the context of designing the improvement of the quality of education at all levels, is among the basic research problems of modern didactics. In the era of transformation, while we face the globalization processes, the issue of education promoting humanization in everyday life becomes particularly important. This makes the humanistic education, associated with, among others, patriotic education and social communication, as well as the culture of language (a living word) become more and more important. This article will focus on the crucial aspects of humanistic education, including language and multicultural education in the interests of improving its quality.

The issue of the essence of the quality of school education as well as academic education - their synonyms, conditions, determinants and expression are reflected in many scientific studies, especially in the works of K. Denek ${ }^{1}$.

We are currently witnessing frequent changes in education, especially in increasing the quality of education and research. Their clarity is disturbed by the fact that they take place in conditions of fierce competition for clients (pupils - students) caused, among others, by demographic decline, socio-economic changes or the requirements of the changing labour market.

\footnotetext{
${ }^{1} \mathrm{~K}$. Denek, Uniwersytet w perspektywie społeczeństwa wiedzy. Nauka i edukacja w uniwersytecie XXI wieku. Poznań 2011; K. Denek, Pomiar efektywności kształcenia w szkole wyższej. Warszawa 1980;
} 
Designing the quality of education and determining its effectiveness is very extensive. In the processes of constructing and implementing innovative solutions, it is important to enter the path of diagnosing the effects of teacher's own activity as soon as possible, which should lead to the modernization of school (and academic) didactics, as well as to the high efficiency of shaping competences on the side of each pupil (student).

\section{Clear formulation of educational goals seen as the basis for the design of improving education quality}

The quality of education at school and university is conditioned by many variables that lie on the side of all participants of educational processes, as well as outside the process. The national and European qualifications framework system is an excellent opportunity for redesigning education with the new guidelines. It requires a fairly careful treatment of the content structure and selection of educational methods in terms of learning outcomes related to the real (not imaginary) competences of each learning entity in three dimensions, respectively knowledge, skills, and social competences. Moreover, it requires a reliable and objective diagnosis and evaluation of the level of didactic work of academic teachers; implementation of pro-quality instruments; creating an incentive system for teachers (academic teachers). The care for the quality of education in the aspect of its design expressed in the multilateral development of the subject (pupil, student) requires continuous improvement in the context of the interaction of teacher / academic teacher $(\mathrm{N}) \leftrightarrow$ pupil / student $(\mathrm{U})$, their corresponding processes, i.e. education (k) and study (s), and variables determining their effects, i.e.: respecting principles $(\mathrm{z})$, setting goals in the category of functions, activities and tasks (c), as well as selection of content $(\mathrm{t})$, educational methods (m), organizational forms (f) adequate for their implementation, together with teaching resources (s), place serving as a base for conducting classes (b), i.e. laboratories and classrooms, lecture auditoriums and all sites not being the school desk, and ways of evaluating (e) the progress of pupils / students that they achieve in educational processes and their own 
work outside the school / university. We thus come to establishing and evaluating the interpretation of the relation $(\mathrm{N} \leftrightarrow U)$ and its effects by seeking answers to the following questions:

1) who (N) educates whom (U)?

2) why (c)?

3) what regularities govern the teaching process ( $\mathrm{z})$ ?

4) what content should this process favour $(t)$ ?

5) what methods, organizational forms and teaching aids to choose and how to do it?

6) how and where to choose the base for the classes? and

7) are the effects achieved realistically adequate to the previously set goals of these educational processes?

All of these elements are important enough to strive to education that would be: smarter, fuller, better, faster, easier and more effective, to the joy of learners and at the same time in order to meet the challenges of the present and future. In general, we come to the determinant of the effectiveness (efficiency) of education (E) as the function $(\varphi)$ of many variables (listed above together with the indications) expressed by the general formula:

$$
\mathrm{E}=\varphi(\mathrm{N} \leftrightarrow \mathrm{U}, \mathrm{c}, \mathrm{z}, \mathrm{t}, \mathrm{m}, \mathrm{f}, \mathrm{s}, \mathrm{b}, \mathrm{e}) .
$$

The structural elements of the educational process presented above and the relationships between them are based on the principle of multivariate (both in kindergarten, at school and at university). They prove the complexity of educational processes and the importance of measuring and evaluating their effectiveness (conceived in terms of the quality of education). It should be emphasized that the principles set out in theories of education (including both learning and teaching) should be thoroughly respected by each teacher in all links and phases of organized situations and educational processes for each student individually - and, at other times, for a competent team member.

The modification of even one of the highlighted elements inevitably entails the modification of the entire educational process seen as a whole 
system. This will be more felt and noticeable in cases of simultaneous modification of several components constituting the structure and the course of educational processes. Relations between learning processes and the environment are also regulated by way of feedback. It can affect globally all of its elements, as well as each of them separately. The influence exerted by clearly defined and formulated educational goals is the most pronounced. They fulfil a superior function over other elements of the education process. This is due to the fact, that each task situation (as an assumed change or innovation) introduced within the didactic process should be adequate to at least one of the goals set.

The so-called "purpose principle" featured in theory assumes the adequacy of all actions taken against individual goals set before their start - actions which are to improve the process seen as a whole, as well as its individual components. K. Sośnicki rightly treats "defining learning objectives as a fundamental task for teaching". the theory of education preferring the unity of goals, content and methods of learning ${ }^{3}$ or the interdependence between goals and the selection of adequate didactic content as well as methods of education and selfeducation $^{4}$.

When attention in education is not paid to a specific and at the same time clear formulation, and then to achieving the goals of education in a university (resulting from the $\mathrm{5}^{5}$ value), all scientific discourses and methodical discussions, which lack values aiming at the improvement of content, methods, forms and means as well as ways of learning, controlling, analysing and evaluating the progress made by students during learning, are not only difficult, but usually pointless.

Due to the huge role of didactic goals in projects related to the improvement of the quality of education, I devoted a lot of attention to

\footnotetext{
${ }^{2}$ K. Sośnicki, Dydaktyka ogólna. Wrocław 1959.

${ }^{3}$ K. Kruszewski, Kształcenie w szkole wyższej. Warszawa 1988.

${ }_{5}^{4}$ J. Bruner, W poszukiwaniu teorii nauczania. Warszawa 1974.

5 J. Mastalski, Aksjologiczne przestrzenie spotkania w edukacji. In: K. Denek, T. Koszczyc, P. Oleśniewicz (eds.), Edukacja jutra. XV Tatrzańskie Seminarium Naukowe. Wrocław 2009.
} 
constructing and designing them in my many years of didactic, educational, scientific and research activity ${ }^{6}$.

For similar reasons, a lot of place in my work as academic teacher and in my scientific research was occupied by the problems of design of didactics (selection and arrangement of the content of education) and docimology (learning, controlling, analysing and evaluating student learning and the examination process). Advanced statistics methods and Markov chains were also used to solve these issues ${ }^{7}$.

Many elements of constructing and designing the improvement of the quality of education in universities can be found in multiple versions of didactic programming ${ }^{8}$.

\section{Designing in educational processes as an object of scientific research}

Designing the improvement of the quality of education at the university consists of harmonious integration of education and upbringing mechanisms in terms of measurable effects in the areas of knowledge, skills and values. Values (recognized and respected) make up the social behaviour of each individual and hence they are the basic element of social competences that have been highlighted in the concept of national qualifications framework ${ }^{9}$. Objective learning of values is one of the most important goals in education ${ }^{10}$.

The psychologists and pedagogues actions pursuing the goals to control the conditions, course and effects of education at various levels

\footnotetext{
${ }^{6}$ K. Denek, Wartości i cele edukacji szkolnej. Poznań - Toruń 1994; K. Denek, I. Kuźniak, Projektowanie celów kształcenia w reformowanej szkole. Poznań 2000; K. Denek, O nowy kształt edukacji. Toruń 1998; K. Denek, Uniwersytet w perspektywie społeczeństwa wiedzy. Dydaktyka akademicka i jej efekty. Poznań 2011.

${ }^{7}$ K. Denek, I. Kuźniak, Kwalifikowanie wiedzy uczniów we współczesnej szkole. Koszalin 1980; K. Denek, J. Gnitecki, R. Meller, A. Mościcki, Struktury dydaktyczne i ich uwarunkowania. Koszalin 1978.

${ }^{8}$ K. Denek, Wplyw nauczania programowanego na edukację $i$ nauki o niej. In: W. Strykowski (eds.), Od nowych technik nauczania do edukacji wirtualnej. Poznań 2006; K. Kruszewski, Nauczanie programowane w systemie dydaktycznym. Warszawa 1974; C. Kupisiewicz, Nauczanie programowane w szkolnictwie wyższym. Warszawa 1974; K. Denek (eds.), Programowanie dydaktyczne w szkole wyższej. Warszawa 1984.

${ }^{9}$ J. Grzesiak, O poprawie jakości edukacji narodowej na forum. In: J. Grzesiak (eds.), Ewaluacja i innowacje w edukacji. Poprawa jakości ksztatcenia. Kalisz - Konin 2012.

${ }^{10}$ W. Chudy, Pedagogia godności. Elementy etyki pedagogicznej. Lublin 2009.
} 
undertaken in the interests of their optimization ${ }^{11}$ are treated as attempts to structure $^{12}$ or design ${ }^{13}$ the educational process. These are, however, synonyms from the group of concepts used in education and research in education, where the same word (term) may take different meanings ${ }^{14}$.

Teaching design is the subject of scientific studies carried out by many Polish didactic researchers, including: F. Bereźnicki, K. Denek, W. Furmanek, J. Gnitecki, J. Grzesiak, S. Juszczyk, W. Kojs, K. Kruszewski, I. Kuźniak, R. Meller, J. Morbitzer, B. Siemieniecki, W. Strykowski, K. Wenta and others. The outstanding teacher and theologian J. Mastalski ${ }^{15}$ notes that in the field of evaluation and innovation of education, including the design of educational processes, the work of J. Grzesiak deserves special attention ${ }^{16}$.

An interesting example of activities that make up the design of a pedagogy course for students of the Faculty of History at the University of Warsaw is included in the didactic skills manual written by K. Kruszewski ${ }^{17}$. Moreover, an interesting proposal for the design of public university management in Poland was developed by C. Kochalski together with a team of collaborators from the Poznań University of Economics. It has interdisciplinary character and goes beyond the issues of narrowly understood strategic management ${ }^{18}$. An equally original design proposal

\footnotetext{
${ }^{11}$ J.K. Babański, Optymalizacja procesu nauczania. Warszawa 1979; K. Denek, Optimalization and a system interpretation of the teasching process as the trend sof the school innovations. „Neodidagmata” 1985, vol. XVII; J. Poplucz, Organizacja czynności nauczycielskich. Warszawa 1982.

${ }^{12}$ R.H. Davis, L.T. Alexander, S.L. Yelon, Konstruowanie systemu kształcenia. Warszawa 1983; J. Grzesiak, Konstruowanie i dobór zadań matematycznych w klasach początkowych. Koszalin 1984.

${ }_{13}^{13}$ R.M. Gagné, L.J. Briggs, W.W. Wager, Zasady projektowania dydaktycznego. Warszawa 1992.

${ }_{14}^{14}$ T. Pawłowski, Tworzenie pojęć w naukach humanistycznych. Warszawa 1986.

15 J. Mastalski, Wspótczesne inhibitory dekomponujące ewaluację w edukacji. In: K. Denek, L. Pawelski, B. Urbaniak, L. Wenta (eds.), Wielkopolskie Forum Pedagogiczne w obliczu ewaluacji $i$ innowacji. Kalisz Szczecinek 2012.

${ }^{16}$ See e.g. J. Grzesiak, Nauczanie ,żywe” i karty pracy we współczesnej szkole, In: K. Denek, T. Koszczyc, P. Oleśniewicz (eds.), Edukacja jutra. XII Tatrzańskie Seminarium Naukowe. Wrocław 2006; J. Grzesiak, Podstawy teorii i metodyki kształcenia praktycznego nauczycieli, Konin 2010; J. Grzesiak, Lekcje i diagnostyka psychopedagogiczna w edukacji dziecka. Konin 2014; J.Grzesiak, Ewaluacja i innowacje w przygotowywaniu procesu lekcyjnego - wyznacznikiem kompetencji nauczycieli. In: J. Grzesiak (eds.), Ewaluacja i innowacje w edukacji, vol. 3, Konin 2007; J. Grzesiak, O powołaniu nauczyciela do żywej metodyki wobec procedur ewaluacyjnych $w$ zmieniajacej się klasie szkolnej. In: J. Grzesiak (eds.), Ewaluacja i innowacje w edukacji, Autoewaluacja i refleksyjność nauczyciela. Konin 2007; J. Grzesiak, Przez analize wartości do postępu pedagogicznego. In: T. Zacharuk (eds.), Ciagłość i zmiana w pedagogice XXI wieku. Siedlce 2007.

${ }_{17}^{17}$ K. Kruszewski, Kształcenie w szkole wyższej. Warszawa 1988.

${ }^{18}$ C. Kochalski (eds.), Model projektowania $i$ wdrażania strategii rozwoju w publicznych szkołach wyższych w Polsce. Poznań 2011.
} 
for ensuring the quality of education at the university was created at the State Higher Vocational School in Konin ${ }^{19}$.

\section{Design and evaluation in education in the light of own research}

Any activity carried out in didactic design will always be accompanied by numerous interfering variables. Their source can be seen in the imperfections of core curricula in schools (and kindergartens), as well as in education standards at universities. Our long-term research indicates that instead of preferring values related to the valuation of knowledge and social competences, the priority is given to the unclear and general formulation of skills or general competences, which often lack practical usefulness.

Education, and even more so language and humanistic education, is quite often characterized by multiplying schemes which are distant from useful knowledge and behavioural norms of the surrounding reality. Language learning treats the development of students' vocabulary too schematically; the knowledge of children, classical literature is treated fragmentary. Language, or more broadly humanistic education in contemporary school often avoids values and valuation on the basis of biasedly selected source content, both in the form of prose or poetry. On the one hand, the pupil is encouraged to read, and on the other hand, little time is devoted to developing speaking and raising the awareness of the beauty of spoken and written language. When pupils in the classroom are asked about what they would like to learn, the questions are apparently conducive and neglect the values inherent in what they should know and understand. The illusory quality of such education is verified by the image of first-year students who do not have the basic knowledge and skills necessary for independent studying and reading of magazines or books.

The results of secondary school-leaving examinations (final exams) are more and more worrying, despite the fact that the sets of exam tasks are

19 J. Grzesiak (eds), Profesjonalne praktyki - profesjonalni nauczyciele. Vol. 1-IX. Konin 2010-2014; J. Jasiński, A. Zimny, Zarzadzanie jakościa kształcenia $w$ szkole wyższej - koncepcja wdrożenia i doskonalenia system. In: J. Grzesiak (eds.), Ewaluacja $i$ innowacje w edukacji. Poprawa jakości kształcenia $i$ jej uwarunkowania. Kalisz - Konin 2012. 
characterized by relatively low standards of requirements for the current core curriculum. However, in relation to the exam with an extended profile, the degree of difficulty of the tasks posed for understandable reasons is much higher. At the same time, it contributes to the widening scale of inefficiency among those students who are otherwise interested in obtaining the highest percentile status deciding about admission to studies. The high school diploma in most subjects is embarrassingly schematic and devoid of humanistic values. As a result, students entering university do not know the content of basic works of literature and have difficulties in assigning their authors to adequate literary periods. The sloppy language, ignorance of philosophical, historical, ethical or moral contexts of the exam raise anxiety and astonishment. it is more and more rare to encounter a student who would be sensitive to the beauty of literature, word, sound, image, or to the beauty of behaviour and clothing. This is due to, among others, to the fact that teachers and parents do not enforce reading books in their entirety, and reading is thus limited to selected fragments, a quarter chapter, two, three paragraphs, several stanzas of songs by J. Kochanowski, or even a quarter of drama by J. Słowacki, or of a comedy by A. Fredro ${ }^{20}$. As a result of the high school final exam constructed in such a way, young people going to universities are not always in a good chance of education adequate to their abilities and skills. The low knowledge of literature, and consequently the low level of the spoken and written language culture mean that more and more bachelor's, master's and even doctoral dissertations contain numerous stylistic, syntactic, grammatical, punctuation and even spelling mistakes. At this point, a reflection arises in the form of the thesis that, in addition to the promoters, the level of preparation of students for writing their diploma theses is also largely the responsibility of school teachers and academic teachers, under the influence of which a given pupil (student) has been developing from the first grade, and even from kindergarten.

\footnotetext{
${ }^{20}$ K. Denek, Czy szkoła może zadbać o poprawność języka polskiego ? „Nowa Szkoła” 2007, nr 4-5.
} 
Therefore, reliable, responsible and, above all, competent actions should be taken to ensure that school children and students grow in language culture, especially on what concerns the values of their native language and broadly understood humanistic education. This requires constant reading, work on the proper autonomous elaboration, as well as a critical assessment of the works of various authors.

The phenomenon of lowering the level and scope of requirements causes careless laziness and unsolicited "partying" in case of most pupils (and students). Such manifestations of lack of values and wisdom are compounded by the actions of a large proportion of teachers and, unfortunately, also academic teachers expressed in artificial and uncritical respect for borrowed "fashionable innovations" such as: joyful school, school closer to the student, stress-free school. This proves the ignorance or disregard of psychological theories and education sciences, which results in the inevitable phenomenon of giving up on the quality of education (including teacher education) on the side of anomies in the form of "joyful mediocrity", which results in a growing number of smug and ignorant arrogants (dumbs), helpless in life, and having an excessively high level of self-assessment of their (non-existent) competences.

Our research also indicates a wide scale of the phenomenon of not using negative assessments, mainly not to be accused of undercutting level school, or in the faculty (department, institute) of the university. This, in turn, leads to a kind of "propaganda of success" characterized by a lack of concern for the reliable and systematic activity of each learning entity towards fulfilling responsible tasks and roles in the future in the region and even the whole country.

It should also be emphasized that the manifestations of fetishization of test-mania, point-mania and surveyors, which are constantly spreading in education, are not conducive to increasing the quality of education, and even more so in the field of humanistic education ${ }^{21}$.

\footnotetext{
${ }^{21}$ J. Grzesiak, Determinanty poprawy jakości w obliczu krajowych ram kwalifikacji - kompetencji. In: J. Grzesiak (eds.), Ewaluacja i innowacja w edukacji. Poprawa jakości ksztatcenia i jej uwarunkowania. Kalisz - Konin 2012.
} 
In the search for ways to improve the effectiveness of education and research, one cannot ignore the issue of the quality of teachers' work as those who decide about the effectiveness of aspirations focused on improving didactics and research in universities ${ }^{22}$. This is all the more necessary in the face of discrepancies between aspirations and the actual effects of their professional work. The symptoms of excessive quantitative aspects of teachers' professional preparation are still worrying at the expense of concern for their qualitative and personal qualifications (ability to reflect and be creative, use of new communication and information technologies, understanding market requirements and the knowledge-based economy, the habit of continuous training and improvement, autonomy, innovation, responsibility, entrepreneurship) ${ }^{23}$.

Indicators are indispensable to evaluate the quality of classes. The basic tools that are useful for assessing the quality of education are: sheets of hospitalization of didactic classes, assessment questionnaires and selfassessments of teachers and academic teachers, reports on the analysis of examinations conducted in individual subjects of study, rankings and plebiscites for the best teachers at school or in the field of education at the university. Our analysis of data obtained in the course of evaluation studies indicates that the participation of students in answering questions regarding the quality of education is too low. In the years 2015-2019, in each semester the percentage of students participating in the study was low and ranged from 3 to $19 \%$ of the total number of students. It is therefore difficult to attribute pro-quality significance to quantitative indicators answering individual survey questions. You can also use guided introspection to study students' opinion surveys about didactic classes on condition that its results are confronted with results obtained by means of objective methods ${ }^{24}$. We are worried that the question requiring the number of student's own working hours for a given subject of study was found to be unanswered in $98 \%$ of all students participating in our research. It can

\footnotetext{
22 Z. Ratajek, Nowy nauczyciel - lider na XXI wiek? „Nowe Horyzonty Edukacji” 2012, nr 3; K. Denek, Uniwersyteckie kształcenie nauczycieli. „Nowa Szkoła” 2013, nr 1.

${ }^{23}$ W. Dróżka, Poszukiwany nowy nauczyciel. „Nowe Horyzonty Edukacji” 2012, nr 1.

${ }^{24}$ W. Okoń, Nowy słownik pedagogiczny. Warszawa 2004.
} 
be assumed that this was due to the small size of using the reading room or studying outside the classroom at home or in the reading room. This issue requires additional research, at least because of the frequent reforming of the education system and evaluation procedures at all levels of education also in relation to teacher education.

\section{Specificity of measurement and indicators of improving the quality of humanities education}

In the area of language and humanities education (including civic and patriotic), particular attention should be paid to the measurability of the results obtained as changes in the social competences of learners under the influence of all participants of educational processes, especially on the part of teachers (and academic teachers). It is also necessary to recognize the close links between social behavior norms (in terms of competence) and the values of knowledge and skills (instrumental skills) in accordance with the principle of the unity of the triad: knowledge - value - efficiency.

The specificity and complexity of humanities education integrated with cultural (and linguistic) education necessitates helping students and their parents learn, discover, feel, understand and prefer values as an ethical norm. There is also a need to support teachers and academic teachers who prepare students to work as teachers who have a complex of educational tasks resulting from the core curriculum and qualifications framework defined by education law ${ }^{25}$.

Our research indicates that evaluation procedures used in school practice and in universities are often reduced to technocratic mechanisms for creating various types of supposed so-called tools for measuring the quality of education. These include: surveys, tests, point criteria, percentage indicators, statements, tables, diagrams, matrixes, lesson observation sheets, evaluation sheets, etc. In fact, their use causes

\footnotetext{
${ }^{25}$ The ordinance of the Ministry of Science and Higher Education of 17 January 2012 on standards of education preparing for the teaching professiona, J.L. 2012, pos. 131; The Ministry of Science and Higher Education regulation of November 2, 2011. on the National Qualifications Framework for higher education, J.L. of 2011, No. 253, pos. 1520, as amended).
} 
excessive burden on teaching staff by schematic formal activities, which usually do not serve to actually improve the quality of education.

Teaching, therefore, faces an urgent and responsible challenge to properly prepare all participants of education for the use of evaluation and self-evaluation in the life of every person on a daily basis and in the process of his work. This is a condition sine qua non to implement the anticipated assumptions of quality evaluation in educational processes. In view of the growing social requirements in teacher education, the basics of "learning to change for the better" and "learning of evaluation" towards the improvement of the quality of own pedagogical work and, consequently, the improvement of the quality of educational processes at all levels can not be missing.

In educational practice, despite the development of the theory of education, there is a scarcity of original ways of determining the actual learning outcomes, which are indicators of the real competences of the pupil (student, future teacher) shaped at a given stage of education. Both in practice and in literature there are numerous controversies regarding qualification of student's achievements. They are caused, among others, by the promotion and fetishisation of simplified methods of controlling and assessing these achievements in the form of so-called tests, and in universities written forms of credits and exams (to a large extent the socalled test ones). This practice has significantly reduced the speaking skills of most pupils and students. Our research also shows that the so-called worksheets and all written forms resulted in a decrease in speaking skills, as well as loosening interpersonal ties in the structure of a school class or student group. The widespread use of written exams at universities contributes to a decrease in the ability to freely use the concepts being studied, as well as a decrease in integration processes between students. This is a very disturbing phenomenon in the face of challenges from the knowledge society, and in particular in relation to the shaping of competences among students preparing to work as a teacher.

First of all, the thread of assessing students in the context of the syllabuses of individual subjects being developed - in close correlation 
between the lecturers and (practical) classes, cannot be omitted. We assume that the education process requires teachers to use optimized didactic measurement tools adequate to the assumed learning outcomes. The specificity of each subject of education and ongoing psychopedagogical diagnostics means that the use of universal, same measurement tools on a regional scale, and even more so nationwide tools, is excluded. Therefore, there is a necessary need for each teacher to develop tools adequate to the conditions of educational situations organized in a specific team of students (pupils). Our evaluation studies (in selected fields of teacher studies) prove that in syllabuses there are numerous records bearing the features of fragmentary fragmentation and excessive generality, which does not contribute to improving the quality of methodological procedures and related measurable results in the form of measurable competence of each student. In the end, passing the course comes to the use of intuitive solutions, which often do not orient both the student and the academic teacher.

\section{Determining the synthetic competence indicator (pupil - student)}

Distinguishing in theory and in syllabuses three categories of learning outcomes ( $\mathrm{W}$ - knowledge, $\mathrm{U}$ - skills and $\mathrm{Z}$ - behaviors) finds its rational justification and does not cause controversy in terms of content ${ }^{26}$. However, in practical solutions the above triad presents many difficulties, especially in determining detailed and measurable indicators of real achievements of studying (learning) entities. This leads to frequent discrepancies and an understandable deviation from theoretical and methodological assumptions. Questions arise about what tools and how to measure students' achievements in each of these three categories of effects, so that it is finally possible to determine the level of their competence in a given subject of study (final semester assessment). In the further part of

\footnotetext{
${ }^{26}$ See e.g. J. Grzesiak, Pewność wiedzy i samodzielność działania w procedurze oceniania studenta $w$ uczelni. Konin 2005; K. Denek, Ewaluacja osiagnięć studentów w nauce oparta na strukturze zdobywania przez nich wiedzy i jej poziomach. In: J. Grzesiak (eds.), Ewaluacja i innowacje w edukacji. Ocenianie skuteczności ksztatcenia w szkole wyższej, Konin 2005; J. Grzesiak, Jakościowe kwalifikowanie kompetencji studentów wobec europejskich standardów edukacji. In: K. Żegnałek (eds.), Edukacja polska w konstelacji europejskiej. Siedlce, 2013.
} 
this discourse, we will focus on presenting the author's concept of measuring the effects of education called "Synthetic Competency Index" (SWK), supported by examples of measuring student's achievements derived from the specifics of teacher studies.

Before sketching the concept of constructing relatively optimal tools for didactic measurement, the following concepts require clarification: learning effectiveness, scope of education, level of education, constancy of learning outcomes and a comprehensive indicator of student's competence.

The distinguished categories of learning outcomes $(\mathrm{W}-\mathrm{U}-\mathrm{Z})$ are global and thus require the definition of specific partial indicators relating to individual criteria describing the diagnosed competences of the student (pupil). In this way, we come to the classification, ordering and also showing the interrelationships between the structural components of the student's competence within one of the subjects studied. Schematically, it can be expressed in the form of the following statement:

1) Knowledge - scope, level and constancy,

2) Skills - scope, level and constancy,

3) Social behavior (competence) - scope, level and constancy.

Let's take a closer look at the indicators appearing in all categories, which are: scope, level and constancy. We will do this first in relation to knowledge.

The scope of knowledge means the quantitative characteristics of the concepts (most importantly understood) adopted by the student. We assume that in education we strive for a state in which every normal (without development deficits) entity has acquired all the basic concepts and facts outlined by the requirements of a given subject or educational program (detailed syllabus of the subject of study). Ignorance of the concept, e.g. "attention" may prevent further effective learning related to this concept, and in the course of studying may even exclude student's activity in diagnosing attention as a mental process of the chosen individual case, e.g. a child starting education in th 1 st class.

The level of knowledge is most often understood as the volumetric characterization of the pupil (student) discernment based on the knowledge 
of a given concept, which takes into account the evaluation of the multiplicity of complementary elements determining the wisdom of that pupil (student). Due to the breadth of knowledge centered around a given term - the concept (fact) can be distinguished and determined hierarchical levels of knowledge on a scale adequate to school (academic) grades . In this context, the following levels of knowledge can be distinguished as a component of pupil-student competence.

a) The level of reproduction of facts - the student uses all concepts on the principle of reproduction in the basic range of remembered (with understanding or not) knowledge (sufficient grade);

b)Level of fact handling - the student uses all concepts with simultaneous exemplification on the basis of literature or own experience (satisfactory plus grade);

c) Analytical level - the student analyzes with elements of comparison and generalization with the use of concepts in relation to practical situations of a typical nature (good grade);

d) Analytical and synthetic level - the student quite efficiently performs analyzes and syntheses using concepts in relation to practical situations of an atypical nature (good plus grade);

e) Level of creative knowledge - the student freely performs analyzes and syntheses with using concepts in relation to practical situations of an unusual nature and designs their own (partly creative) solutions (very good grade).

Similarly, refer to the hierarchy of criteria in the other two categories, namely skills and behavior. Because far-reaching similarities to the hierarchy presented above we refrain from discussing them in detail. However, it should be emphasized that all categories of learning outcomes are subject to evaluation procedures (evaluation or self-evaluation) while respecting the standards, which in each case are: scope, level and stability.

Regarding the criterion of constancy, it should be noted that in the practice of final qualification of student competences this criterion is usually not taken into account. The justification for this approach may be that the student takes the exam (credit) immediately after a period of 
intensive preparation for it and thus it is difficult to objectively determine how long the acquired knowledge will be remembered. In our concept, the indicator of the constancy of shaped competences can be determined in the following cases:

1) in all stages, especially in the final phase of the educational process according to the classically defined didactic principle of constancy,

2) the competences shaped in one subject of study are multiplied in studying other subjects (cross-subject correlation) and

3 ) when the subject is continued in the next semesters of education intra-object correlation)

Of course, the criteria presented above require careful clarification due to the assumptions and specificity of each subject of education at school or university. The care for clarity and measurability of the records results in the creation of specific didactic measurement tools that take into account all distinguished criteria and categories of qualification and verification of learning outcomes on the side of each student (pupil) as fully as possible.

Depending on the nature of the subject of education and the forms in which it is implemented, a synthetic formula is determined estabilshing the algorithm for determining the student's comprehensive competence index (SWK). If in the study plan a given subject is implemented in the form of lectures as well as exercises in connection with the system of pedagogical practice at school, and the nature of the subject is interdisciplinary and also has a high coherence rate - a high rank should be assigned to the following spheres: instrumental as well as the active participation of students in classes at the university and at school during apprenticeship. No less importance should be attached to the student's own work in studying literature (indicated and chosen at the student's own discretion).

The synthetic index (SWK) comprehensively expresses the sum of all partial indicators taking into account the agreed proportions between the ranks of knowledge $(a)$, skills $(b)$ and social behavior $(c)$ student's. For example, this can be illustrated on the subject of "psycho-pedagogical diagnosis", which occurs in the author's academic work. In constructing 
the syllabus of this subject in consultation with students of distinguished ranks $a, b, c$ the following values have been assigned:

$$
a=45 \%, b=35 \%, c=20 \% \text {. }
$$

It should be noted that there is equality in every case $a+b+c=100 \%$.

The above parameters reflect the rank of individual planes of the subject of education (WUZ) taken into account in determining the student's assumed competences. Psycho-pedagogical diagnostics is the subject that is the canvas for shaping the broadly understood methodological competences of future teachers (e.g. children). Hence, the rankings of knowledge (45\%), practical skills (35\%) and social competences (20\%) were assigned in that way. One should agree that there are no clear and objective proportions between ranks $a, b$ and c. Hence, it is advisable that the solutions to this issue in each case were treated in the dialogue between the lecturer and students.

From the theoretical foundations of didactic metrology (docymology), there are premises for determining a synthetic indicator (SWK) characterized by a system approach. In the course of our many years of research, the concept of student evaluation and evaluation - as a future teacher - has been developed and verified. Diagnosis of student's achievements during the exam (taking into account his progress throughout the semester) included all of the above-mentioned elements that were as far as possible devoid of the characteristics of harmful score-mania or testmania.

In view of the considerations made on the basis of longitudinal studies, we come to the determination of a synthetic indicator of student's competence, which is expressed by the following formula:

$\mathbf{S W K}=\boldsymbol{a} \times \mathbf{W}+\boldsymbol{b} \times \mathbf{b} \times \mathbf{U}+\boldsymbol{c} \times \mathbf{Z}$, where $a+b+c=1(100 \%)$

$\mathrm{W}-$ partial indicator in the knowledge category,

$\mathrm{U}$ - partial indicator in the skill category,

$\mathrm{Z}$ - partial indicator in the category of social competences (behaviors).

In view of the adopted methodological assumptions, in the further procedure of determining the level of education quality on the student's 
side, the comprehensive index obtained by him should be assigned to a given range determining the grade according to the scale defined in the study regulations. The SWK index can take values from the range $\langle 2 ; 5>$ and on this basis it can be used to determine the final grade in a given subject.

The SWK determination procedure requires the teacher to perform ongoing diagnostics in the course of teaching, and to take into account all distinguished components, which in total will determine the qualification of each student's achievements and their final assessment. Of course, you cannot ignore the elements of self-control, self-correction and selfassessment on the part of individual students. Student's competences in self-control as well as self-corrections and self-assessments are the primary component of the synthetic competence index in general.

Developing tools for measuring the quality of education is the subject of many years of research and design work in a team of academic teachers and participants of a scientific seminar under the guidance of the author of this article. Students of "pedagogy" are included in the process of creating research tools and didactic measurement tools, and members of student research clubs actively participate in this field. Classes with students include the construction of measurement tools and their empirical verification in connection with the implementation of the following subjects of study: psychopedagogical diagnostics, modeling of elementary education space, theory and methodology of elementary education of a child, shaping the child's competence in the context of the core curriculum, methodology of social research and finally evaluation in education kids. Our research has proved that it is worth including students in the current of research trials to improve the quality of education of children and their teachers. This is particularly important and significant in shaping the competences of future teachers in the fields of humanities and language and literary education. 


\section{CONCLUSIONS}

The methodology of measuring and evaluating effects obtained in the process of educational classes in contemporary school is gaining importance and will probably continue to do so. In the search for better quality in/of education of tomorrow we encounter a significant gap between theory and implementation in educational practice. For this reason, it turns out that it is be necessary to conduct more extensive didactic research (including that of diagnostic and experimental nature) on the quality of education and teachers' education, which requires constructing qualitative tools for measuring the effects of education (and upbringing). The question of performing teaching roles in the education of students getting ready to work as teachers in the system of pedagogical practice becomes particularly significant.

In practice the activity of students is quite often reduced to tedious cramming of the educational content not always useful in their professional work. Student internship at school and practical classes at the university should be closely correlated, fully focused on shaping competencies necessary to perform multiple tasks and responsibilities - in order to perform competent and responsible roles in teaching work ${ }^{27}$.

Identifying (complaining on) or even justifying something that is imperfect or even bad in education is not enough. We need strong, competent and responsible cooperation of all educational entities oriented towards actual changes for the better. This applies to, among others, the design of research on qualitative didactic measurement tools, as well as experimental research related to issues concerning diploma theses, especially at the level of master's studies. It is an extremely responsible task faced by both school and academic didactics. All school and academic teachers should be reciprocally supported and assisted in their didactic and educational activities. This however will not be possible if didactics as

\footnotetext{
${ }^{27}$ See e.g. J. Grzesiak, Niepokój o dydaktykę w procedurze ewaluacji edukacji i nauk o niej. In: J. Grzesiak (eds.), Ewaluacja i innowacje w edukacji. Kalisz - Konin 2014; J. Grzesiak, Syntetyczny wskaźnik kompetencji uczniastuży poprawie jakości edukacji - kiedy? In: J. Grzesiak (eds.), Narzędzia pomiaru efektów kształcenia. Kalisz 2016.
} 
pedagogical subdiscipline will be underestimated in the first place by theoreticians and academic teachers, who perform responsible roles of teachers of future teachers. The idea is not to allow undermining or even losing the identity of didactics as a leading subdiscipline of pedagogy, integrally connected with detailed didactics and various forms of pedagogical practice. This is particularly important in the view of the challenges posed by education in the scope of humanities in the linguistic and cultural context.

General didactics, including didactic design, as subject of pedagogical studies, should constitute a thorough base consisting in theory of knowledge and utilitarian skills for shaping students' competences in the area of pedagogical methodology, taking into account the specificity of the subject and the level of education. It depends mainly on teachers teaching didactics as well as on teachers - methodologists, between whom there should be closer cooperation and correlation.

Studies of didactic sources constitute a special scientific canvas for discourses and meditations on, inter alia:

- past changes in various areas of education resulting from the influence of the teacher's methodical behavior - both in relation to theory and school practice,

- what should be changed in the didactic measurement so that there is undoubted pedagogical progress as a measure and at the same time as an indicator of improving the quality of education in general.

Continuing didactic discourses and disseminating good publications among teachers and students is indispensable for further pedagogical day-to-day progress in all schools and universities. Individual actions and research or innovative attempts undoubtedly have social significance, but only coherent, extensive activity of all school and academic teachers can make the problem of determining a synthetic indicator of pupil- student competence considered in this article become an important step forward in improving the quality of education in each school and at each university. 


\section{SUMMARY}

In the article, the author engages in scientific and to large extent methodological considerations regarding the improvement of the quality of education in the scope of humanities (including language) in the context of the quality of didactic measuring tools. He is in favor of designing genuinely better methodological solutions leading to an actual increase in the effectiveness of shaping the competences of pupils and students. Moreover, he presents theoretical and methodological premises for the construction of high-quality didactic measurement tools on the basis of which innovative works can be conducted aimed at improving the quality of education. In this context, there is a need for qualitative change for widespread and continuous innovation in education and correlated sciences. It is a very responsible challenge for educators, teachers and practitioners who are decisive for the sense and authentic values inherent in everyday live education.

The structure of the discourse includes sequences devoted to the following issues: clarity in the formulation of educational goals at the basis of designing improvement of education quality, design in educational processes as subject of scientific research, design and evaluation in education in the light of original research, specificity of measurement and indicators of improving quality of humanistic education, concept for determining a synthetic competency indicator (pupil - student).

The basis for determining the quality of education, especially in the scope of humanities (including language education) in the era of transformation processes, should consist in its goals, expressed in clear formulations of functions, activities and detailed methodological and organizational tasks. Such formulas should at the same time clearly set measurable results as assumed specific competences of individual pupils (students). It has been proved in the article that in the pursuit of improving the quality of education, teaching (at both schools and universities) should be prioritized towards assumed operational goals, which in reality can be treated as assumed effects in the form of changes in competences (of the pupil - student) for richer and more perfect. However, goals should not be identified with teaching outcomes. 
Based on the set operational goals and ongoing psychological and pedagogical diagnostics of individual pupils / students it becomes possible to design the course of phased educational processes. These processes should, by definition (and set goals), trigger change in every learning subject, and that in turn requires reliable diagnosis based on stimulus - reaction - effect type of feedback. The article features original concept of comprehensive day-to-day didactic measurement entitled 'synthetic competence indicator'. Theoretical considerations were supported with examples and interpretations in the context of the author's long-term research.

Finally, the author presents valuable demands and challenges in the name of improving the quality of education, especially in the scope of humanities (including linguistic and cultural education). The author also pays particular attention to the importance of the quality of educating competent and responsible teachers, who thanks to acquired competences will be able to cope with the requirements and tasks. These challenges also apply to academics and academic teachers, especially those appointed as teachers of (future) teachers.

\section{REFERENCES}

1. J. K. Babański, Optymalizacja procesu nauczania. Warszawa 1979.

2. J. Bruner, W poszukiwaniu teorii nauczania. Warszawa 1974.

3. W. Chudy, Pedagogia godności. Elementy etyki pedagogicznej. Lublin 2009.

4. R.H. Davis, L.T. Alexander, S.L. Yelon, Konstruowanie systemu ksztatcenia. Warszawa 1983.

5. K. Denek, Uniwersytet $w$ perspektywie społeczeństwa wiedzy. Nauka i edukacja w uniwersytecie XXI wieku.Poznań 2011.

6. K. Denek, Pomiar efektywności kształcenia w szkole wyższej. Warszawa 1980.

7. K. Denek, O nowy ksztalt edukacji. Torun 1998.

8. K. Denek, Uniwersytet $w$ perspektywie spoleczeństwa wiedzy. Dydaktyka akademicka i jej efekty. Poznań 2011.

9. K. Denek, Wartości i cele edukacji szkolnej. Poznań - Toruń 1994. 
10. K. Denek, I. Kuźniak, Projektowanie celów ksztatcenia w reformowanej szkole. Poznań 2000.

11.K. Denek, J. Gnitecki, R. Meller, A. Mościcki, Struktury dydaktyczne i ich uwarunkowania. Koszalin 1978.

12. K. Denek, Optimalization and a system interpretation of the teasching process as the trend sof the school innovations. „Neodidagmata” 1985, vol. XVII.

13. K. Denek, I. Kuźniak, Kwalifikowanie wiedzy uczniów we wspótczesnej szkole. Koszalin 1980.

14. K. Denek (eds.), Programowanie dydaktyczne w szkole wyższej. Warszawa 1984.

15.K. Denek, Czy szkoła może zadbać o poprawność języka polskiego? „Nowa Szkoła” 2007, nr 4-5.

16. K. Denek, Uniwersyteckie kształcenie nauczycieli. „Nowa Szkoła” 2013, nr 1.

17. K. Denek, Ewaluacja osiagnięć studentów w nauce oparta na strukturze zdobywania przez nich wiedzy i jej poziomach. In: J. Grzesiak (eds.), Ewaluacja $i$ innowacje $w$ edukacji. Ocenianie skuteczności kształcenia w szkole wyższej, Konin 2005.

18. K. Denek, Wplyw nauczania programowanego na edukację i nauki o niej. In: W. Strykowski (eds.), Od nowych technik nauczania do edukacji wirtualnej. Poznań 2006.

19. W. Dróżka, Poszukiwany nowy nauczyciel. „Nowe Horyzonty Edukacji” 2012, nr 1.

20. R.M. Gagné, L.J. Briggs, W.W. Wager, Zasady projektowania dydaktycznego. Warszawa 1992.

21. J. Grzesiak, O poprawie jakości edukacji narodowej na forum. In: J. Grzesiak (eds.), Ewaluacja i innowacje w edukacji. Poprawa jakości ksztatcenia. Kalisz - Konin 2012.

22. J. Grzesiak, Konstruowanie $i$ dobór zadań matematycznych $w$ klasach poczatkowych. Koszalin 1984.

23. J. Grzesiak, Podstawy teorii i metodyki ksztatcenia praktycznego nauczycieli, Konin 2010. 
24. J. Grzesiak, Lekcje i diagnostyka psychopedagogiczna $w$ edukacji dziecka. Konin 2014.

25. J. Grzesiak, Ewaluacja i innowacje w przygotowywaniu procesu lekcyjnego - wyznacznikiem kompetencji nauczycieli. In: J. Grzesiak (eds.), Ewaluacja i innowacje w edukacji, vol. 3, Konin 2007.

26. J. Grzesiak, Nauczanie „żywe” $i$ karty pracy we współczesnej szkole. In: K. Denek, T. Koszczyc, P. Oleśniewicz (eds.), Edukacja jutra. XII Tatrzańskie Seminarium Naukowe. Wrocław 2006.

27. J. Grzesiak, O powołaniu nauczyciela do żywej metodyki wobec procedur ewaluacyjnych $w$ zmieniajacej się klasie szkolnej. In: J. Grzesiak (eds.), Ewaluacja i innowacje w edukacji, Autoewaluacja i refleksyjność nauczyciela. Konin 2007.

28. J. Grzesiak, Przez analizę wartości do postępu pedagogicznego. In: T. Zacharuk (eds.), Ciagłość i zmiana w pedagogice XXI wieku. Siedlce 2007.

29. J. Grzesiak, Pewność wiedzy $i$ samodzielność działania $w$ procedurze oceniania studenta w uczelni. Konin 2005.

30. J. Grzesiak, Niepokój o dydaktyke w procedurze ewaluacji edukacji $i$ nauk o niej. In: J. Grzesiak (eds.),Ewaluacja $i$ innowacje $w$ edukacji. Kalisz - Konin 2014.

31.J. Grzesiak, Syntetyczny wskaźnik kompetencji uczniastuży poprawie jakości edukacji - kiedy? In: J. Grzesiak (eds.), Narzędzia pomiaru efektów kształcenia. Kalisz 2016.

32. J. Grzesiak, Determinanty poprawy jakości w obliczu krajowych ram kwalifikacji - kompetencji. In: J. Grzesiak (eds.), Ewaluacja $i$ innowacja w edukacji. Poprawa jakości kształcenia i jej uwarunkowania. Kalisz - Konin 2012.

33. J. Grzesiak, Jakościowe kwalifikowanie kompetencji studentów wobec europejskich standardów edukacji. In: K. Żegnałek (eds.), Edukacja polska w konstelacji europejskiej. Siedlce, 2013.

34. J. Grzesiak (eds), Profesjonalne praktyki - profesjonalni nauczyciele. Vol. 1 - IX. Konin 2010 - 2014.

35. J. Jasiński, A. Zimny, Zarządzanie jakościa kształcenia w szkole wyższej - koncepcja wdrożenia $i$ doskonalenia system. In: J. Grzesiak 
(eds.), Ewaluacja i innowacje w edukacji. Poprawa jakości ksztatcenia i jej uwarunkowania. Kalisz - Konin 2012.

36. C. Kochalski (eds.), Model projektowania $i$ wdrażania strategii rozwoju w publicznych szkołach wyższych w Polsce. Poznań 2011.

37. K. Kruszewski, Kształcenie w szkole wyższej. Warszawa 1988.

38. K. Kruszewski, Nauczanie programowane $w$ systemie dydaktycznym. Warszawa 1974.

39. C. Kupisiewicz, Nauczanie programowane w szkolnictwie wyższym. Warszawa 1974.

40. J. Mastalski, Współczesne inhibitory dekomponujące ewaluację w edukacji. In: K. Denek, L. Pawelski, B. Urbanek, L. Wenta (eds.), Wielkopolskie Forum Pedagogiczne $w$ obliczu ewaluacji $i$ innowacji. Kalisz-Szczecinek 2012.

41. J. Mastalski, Aksjologiczne przestrzenie spotkania w edukacji. In: K. Denek, T. Koszczyc, P. Oleśniewicz (eds.), Edukacja jutra. XV Tatrzańskie Seminarium Naukowe. Wrocław 2009.

42. K. Kruszewski, Kształcenie w szkole wyższej. Warszawa 1988.

43. W. Okoń, Nowy słownik pedagogiczny. Warszawa 2004.

44. T. Pawłowski, Tworzenie pojęć w naukach humanistycznych. Warszawa 1986.

45. J. Poplucz, Organizacja czynności nauczycielskich. Warszawa 1982.

46.Z. Ratajek, Nowy nauczyciel - lider na XXI wiek? „Nowe Horyzonty Edukacji” 2012, nr 3.

47. K. Sośnicki, Dydaktyka ogólna. Wrocław 1959.

\section{Information about the author: \\ Grzesiak Jan}

Dr hab. in the Field of Pedagogical Sciences, Professor at the Department of Pedagogy and Social Work, State School of Higher Professional Education in Konin 4, Popiełuszki str., Konin, 62-510, Poland 


\section{EDUCATIONAL IDEAL IN THE PEDAGOGICAL WORKS OF WESTERN UKRAINE IN THE INTERWAR PERIOD}

\section{Nevmerzhytska O.}

\section{INTRODUCTION}

The interwar period in Western Ukrainian lands (Eastern Galicia, Transcarpathia) is characterized by the formation of civil society, the rise of the national spirit, the development of the national school system. According to the Treaty of Saint-Germain (1919), Volhynia, Eastern Galicia, Chelm Land, Podlachia and Nadsania were under Polish rule. The situation of the Ukrainian lands during this period was ambiguous. On the one hand, Poland declared a course on the development of a democratic society, ensuring the development of national minorities, but on the other, this period was characterized by an aggravation of the national issue and discriminatory actions of the government on the rights of Ukrainians.

Despite the artificial suppression of the economic development of Galician villages, religious pressure and the ban on the activities of individual Ukrainian parties and public cultural and educational organizations, there were several vigorous parties (Prosvita, Native School Pedagogical Society, etc.) and youth societies (Plast, Sokol, Sich, Orly, Luh, etc.), and the system of private national schooling was being actively developed at the time. The expansive actions of the Polish authorities provoked active opposition and development of civil society in Eastern Galicia.

The conditions for the development of civil society in the Transcarpathian lands were even more favorable, since Czechoslovakia was much more democratic than Poland. Its leadership policy, led by Tomáš Masaryk, contributed to the development of political life, the establishment of nearly three dozen political parties that had different, often diametrically opposite views on the social development of the region, 
its economic opportunities, as well as Ukrainian national schooling. Thus, Vira Fedelesh, a teacher of history of the Mukachevo Civic School wrote about this period in a textbook on the history of Subcarpathian Ukraine: the government is carried out in the Slavic spirit. Public schools are Ruthenian and Ruthenian language is studied as a compulsory subject in each one of them. "May our Subcarpathian Ruthenia always be Ruthenian and may the Ruthenian culture flourish in it at all times"1.

The most difficult situation was in Bukovyna. After its occupation by Romania, the process of curtailing its previous achievements took place. Bukovyna's autonomous rights were abolished and it was transformed into the province of Romania. Romanianization of all spheres of life took place in the land: the use of the Ukrainian language was forbidden, the Ukrainian schools, cultural and educational institutions, as well as magazines were shut down. However, even under these difficult circumstances, Ukrainians tried to defend their rights, and the most vivid expression of the national liberation movement was acquired in the activities of the Organization of Ukrainian Nationalists.

The uprising at the site of the dynastic new nation states set the important task of self-reliance and self-affirmation before them, and it could not be achieved without the proper education of citizens before the realization of new state-building tasks. Therefore, the priority of the school's activity was the state-civic education of different content, depending on the political ideologies of the new states to which the school's intellectual and educational goal was subordinated. According to Yakym Yarema, the problem of the school became a matter of national importance. The author has analyzed the ideological underpinnings of the activity of European schools, pointing out that the focus of school-based education has become social-class education and upbringing in Eastern Europe and national education and upbringing in the West. And if social education aims to educate "socially and internationally-minded activists", the national education tries to be "a hotbed of state-national patriot

\footnotetext{
${ }^{1}$ Феделешъ В.И. Учебникъ исторіи Подкарпатской Руси отъ найдавнЂйшихъ временъ до днешнихъ дней и Чехословакіи до XIV. вЂека. Мукачево : Типографія «Карпатія», 1922. С. 32.
} 
activists. There is a spirit of internationalism which, in its essence, is merely an expression of Moscow's national aspirations for power over the world, that took possession of the school; here, multicolored nationalism is pushed into the school, making it, depending on the nation-state, its traditions, historical claims and aspirations, a multifaceted instrument of its great-power politics". Therefore, according to the author, the school has entered a phase of deep state-national differentiation, filling itself with peculiar content and serving different social and political ideologies, ideals and worldviews in each state ${ }^{2}$.

This can be easily traced to the justification of the educational ideal of the Polish (Western Ukrainian lands were part of the Second Commonwealth at the time) and Western Ukrainian educators.

\section{Educational ideal in Polish pedagogy}

At the beginning of the twentieth century, Polish educators substantiated the ideal of an "honest person and a good citizen", which was similar to pan-European expectations, but was based on the opinions, desires, and postulates of the national elite [30]. More broadly, the Polish educational ideal is presented in the writings of Galician teacher Irena Pannenkova. She studied at Lviv University and later worked in secondary schools of Galicia.

According to the educator, the main purpose of education is to prepare a person for the fulfillment of life's tasks mainly as an individual according to the innate forces, needs and abilities (individual education), as the son or daughter of their nation in relation to society (civic education), as a representative of their own era in relation to the rest of humanity (public education) and as an immortal being in relation to God (religious education) $)^{3}$.

In the work "Thoughts On Folk Education" Pannenkova argued that the ideal can be natural or artificial, clearly delineated or inaccurate and blurred. But it is always folk, and so is education. Its tasks are to rely on

\footnotetext{
2 Ярема Я. Нова фаза в розвитку європейської школи. Українська Школа. 1934. Річник ХІХ. С. 3-11.

${ }^{3}$ Pannenkowa I. Nasze zadania wychowawcze. Warszawa, 1929. S. 6.
} 
national character as the natural source and foundation of pedagogical works, to improve people's natural inclinations and to eliminate and smoothen its negative features ${ }^{4}$.

Recognizing that each nation creates an educational ideal according to its peculiarities and needs, Irena Pannenkova tries to identify the basic features of the Polish psyche. She believes that the Polish psyche emphasizes the dependence of the common cause on the individual attitude, and especially on the moral state of each individual. It embodies the desire for freedom and its worship as the highest good on earth ${ }^{5}$. The Polish people are individualistic in nature and universal in their tendency. At the same time, in the Polish soul the most capable of development is the moral side.

When speaking about the Polish ideal of education, a citizen must be brought up with the following basic features: independence and creativity, civic responsibility. The first task of public education should be the development of qualities such as the ability to think independently, the ability to control oneself and moral independence. Appropriate moral and religious culture, capacity for introspection and self-criticism, sober and fair judgments about people and things, cult of tradition, love for truth, honor for true merit, ability for sacrifice and submission, and above all love for the Motherland, to which individual creativity is rooted and to which it is driven, are the traits that give rise to a sense of civic responsibility. An individual who has a healthy body, developed intelligence and unbreakable will becomes a perfect, malleable tool in their own life work, in creative and responsible actions - a human being not only with blood and body, but also with the movement of their soul, the strongest knots of thoughts and feelings united with their land and the people among which they were raised and to which they return with their creativity, devoting their lives to serving for the People, humanity and

\footnotetext{
${ }^{4}$ Pannenkowa I. Myśli o wychowaniu narodowem. Lwów : Nakł. «Polskiego T-wa pedagogicznego», 1918. S. 35

Pannenkowa I. Myśli o wychowaniu narodowem. Lwów: Nakł. «Polskiego T-wa pedagogicznego», 1918. S. 14-19.
} 
God. Such is a complete and individual person, a citizen, and a creator. This is the ideal, this is the purpose of folk education in Poland ${ }^{6}$.

However, when analyzing the situation in Galician schools, the scientist concluded that their deviation from the ideal in public education is simply frightening. Irena Pannenkova gave the following example. Galician school, trained on German models, is burdened with their lethal leveling of the individuality of pupils and overburdening of thinking, on the one hand, and neglect of religious and moral education, as well as levity of physical education as a duty of the school, on the other ${ }^{7}$.

In our opinion, the educational process in Galician schools was slowed down not only by the above-mentioned factors. It should be added that the efforts of the Ukrainian youth to educate the patriots of the Polish state on the models of Polish culture and language significantly complicated and hampered this process. After all, Konstantin Ushinsky wrote that "despite the similarity of the pedagogical forms of all European countries, each of them has its own special national education system, its own special purpose, and its own special means of achieving this goal"8.

The purpose of Polish education described by Irena Pannenkova has a noble character, is aimed at forming a creative, competent personality, an individual who serves the Motherland and God, and is in many respects consistent with the purpose of modern Ukrainian education. But what constitutes the basis of Polish education may not fully serve the formation of Ukrainians, as they have their own natural features, mentality and aspirations, as well as their own path. The inability to be brought up in their native language and on their own national customs, traditions, legends, history and literature hindered the development of Ukrainian children and youth, and therefore did not contribute to the social progress of Galicia.

\footnotetext{
6 Pannenkowa I. Myśli o wychowaniu narodowem. Lwów : Nakł. «Polskiego T-wa pedagogicznego», 1918. S. 38-41.

Pannenkowa I. Myśli o wychowaniu narodowem. Lwów: Nakł. «Polskiego T-wa pedagogicznego», 1918. S. 34.

${ }_{8}$ Ушинський К. Про народність у громадському вихованні. Вибрані педагогічні твори : у 2-х т. К. : Радянська школа, 1983. Т. 1. С. 47.
} 


\section{Ukrainian educational ideal in the heritage of educators of the interwar period}

After World War I, the problem of finding a new Ukrainian educational ideal was also aggravated in Western Ukrainian lands. "In the field of education there is a majestic scientific movement, passionate search for new truths and ideals of education"".

In contrast to the Polish educational ideal, a patriot citizen who believes in God and obeys His commandments, Ukrainian educators have sought to create a Ukrainian educational ideal that, in a stateless Ukraine, would help preserve national identity, promote political, economic and cultural development in Eastern Galicia. Therefore, this ideal was formed taking into account the influences of Western European pedagogy and the needs of the Ukrainian people and consisted in the formation of an educated and honest person, a useful member of society with a strong and healthy body and spirit ${ }^{10}$. The main emphasis was on the harmonious development of all the forces of the child: "The ideal of modern education aims at the uniform development of all the abilities of the child. This uniform development leads to the attainment of the harmonious integrity of an individual"11. This task has arisen in the context of seeking by not only Ukrainian but also Western European educators, who emphasized the priority of education. The school was given a task of educating a person for the needs of life. In this case, education became a means of upbringing and a way of attaining an educational goal.

The idea of educational training in which the national culture plays a major role was developed in the heritage of Galician educators. Since culture is extremely broad, its educational values (religious, moral, social, aesthetic, economic) can be found both in the content of the educational material and in the school life itself ${ }^{12}$. The starting point of education, according to Ivan Velyhorskyi, is the teaching of life on the basis of native culture. "The goal is to create a new type of person on the basis of the

\footnotetext{
9 Ющишин І. Колективізм чи індивідуалізм: Завваги до громадівських інстинктів нашого народу. Шлях виховання і навчання. 1930. Ч. 5. С. 130.

${ }_{11}^{10}$ Макарушка О. Наука вихованя : [підручник для шкіл і родин]. Львів : Накладом автора, 1922. С. 3.

${ }_{11}^{11}$ Куцій М. Естетичне виховання. Шлях навчання і виховання. 1928. Ч. 1. С. 23.

12 Терлецький Г. Виховне навчання. Львів, 1939. 19 с.
} 
national tradition, an independent, ready-for-life individual who can draw from the past, look wisely at the present and have faith in the future, with the desire for active cooperation in building a better Tomorrow"13.

The continuation of these scientific studies was to substantiate the basic principles of national education. In this context, Yaroslav Kuzmiv constructed a reasoning on the basis of a value approach and turned to the field of pedagogy of culture. By the term "culture", he meant not so much the cultural values which are being produced, but rather the spiritual process which takes place on their basis (customs, morals, religion, art, science, language, economic values, literature, etc.). Therefore, according to Kuzmiv, education is the introduction of the child into the world of cultural values (understanding them as a continuous process) "which are never complete", and therefore the task of education can never be fully achieved. In view of this, the author has justified several statements:

1) education is a continuous realization of cultural values among the youth, who must not only be their bearers, but also creators;

2) since no culture exists abstractly, outside the nation, "every true and complete education cannot be national";

3) the tasks of national education are: a) awakening and continuous strengthening of national consciousness; b) uniting all layers of the nation around common national ideals; c) awakening and development of the genius of the people in the field of thought and joint efforts; d) the development of good national traits and the elimination or reduction of undesirable ones.

In view of the above, Yaroslav Kuzmiv substantiated the ideal of education, a new type of person, "equipped with the most desirable, useful (physical and mental) traits, an individual who feeds on the achievements of past generations and is conscious of their spiritual connection with them, a person who multiplies and deepens national culture and brings its values into the cultural treasury of the world through their creative efforts..."14.

\footnotetext{
${ }^{13}$ Велигорський І. Українознавство. Украйнська школа. 1934. Ч. 19. С. 2-15.

${ }^{14}$ Кузьмів Я. Напрямні національного виховання. Периий Украӥнський Педагогічний Конгрес у Львові (1935). Львів, 1938. С. 191-194.
} 
The necessity of forming a generation that is conscious of the purpose of their nation, capable of building a state and educating the "state-building youth", was supplemented by Vasyl Pachovskyi. The educator specified the spiritual values which should be instilled in the young generation "so that they are ready for the greatest sacrifices for them". In particular, he drew attention to national self-respect, personal dignity and pride in belonging to the Ukrainian nation, which is an equal culture with that of other state peoples. He noted that blatant rudeness among pupils should be replaced with a sense of dignity and honor. There should be obedience to the state power instead of betrayal and discipline instead of political prostitution, submission to the leadership authority instead of peskiness and subordination to the organized church instead of religious sectarianism, coordination of state necessity instead of political anarchism and systematic work on the transformation of the nation into "a disciplined material for state building" instead of explosive mysticism ${ }^{15}$.

According to Stepan Rudnytskyi, an important value of national education is the love of the motherland, which means not only love for one's home, native village, town or a neighborhood, but love for all the land and space "where people speak their mother tongue, abide by their native customs, live with their memories of the past and cherish their hopes for the future!.. As Ukrainians, we need to firmly love all that is good and beautiful about Ukraine and to eschew everything that is evil and bad, and to work hard to keep it out of Ukraine"16. Involvement of regional values in the upbringing should also help to shape such a personality. After all, according to Stepan Malaniuk, they have grown into the psyche of everyone who lives in a particular locality and has a great incentive force for social work. That is why it is important to study the local values of your people and to base creative work on them for the economic and cultural upbringing of the nation ${ }^{17}$.

\footnotetext{
15 Пачовський В. Українознавство у вихованні молоді. Периий Украйнський Педагогічний Конгрес у Львові (1935). Львів, 1938. С. 89-113.

${ }_{17}^{16}$ Рудницький С. Україна наш рідний край: Коротка географія. Львів, 1921. С. 5-8.

17 Маланюк С. Місцеві цінності в скарбниці національного виховання Методика і шкільна практика: Додаток до часопису «Шлях виховання й навчання». 1933. С. 203-211.
} 
According to Western educators, the involvement of children and youth in civic values is an extremely important task. In times of liberation (1918), Ivan Boberskyi chose the following words as an epigraph for his diary: "A good state is the pinnacle of human creativity on earth. Each member of the state system must fulfill their duty flawlessly, like the wheel in the clock"18. In order to do this, they must absorb a number of values of civic life, as emphasized by Yaroslav Kuzmiv, Myroslav Semchyshyn and Ivan Yushchyshyn. A school which would provide not only valuable education but also bring up active, conscious, creative, useful, able-bodied and productive citizens was considered by educators an important institution of civic education ${ }^{19}$.

Religious and moral education was also declared an important task of educational institutions. The resolutions and regulations of the First Ukrainian Pedagogical Congress stated that it was only appropriate to have a system of upbringing based on Christian faith, science, and morality. The same document defines the importance of the implementation of national, social, artistic, spiritual, hygienic and physical education which gives the opportunity to fully prepare Ukrainian youth for the realization of the highest ideal of the nation, the effective creative participation in the development of native spiritual and material culture, as well as participation in universal human culture as a whole ${ }^{20}$.

The Galician educators paid considerable attention to aesthetic education. In particular, Matviy Kutsiy noted that "the modern school also takes thorough care of aesthetic education. To educate aesthetically is to awaken the feelings of beauty, the ability to feel and touch it, and finally to observe the beauty in nature and art" ${ }^{21}$.

Peter Bilaniuk considered the character (and not the intellect, as it was in the era of the development of positivism) to be the ideal of the post-war

\footnotetext{
${ }^{18}$ ЦДАВО України. Ф. 4379. Оп. 1. Спр. 21. Щоденник Боберського І. за 1918-1919 pp., 28 серпня 1944 р. Арк. 2.

19 Кузьмів Я. Шкільні характеристики учнів. Шлях виховання й навчання. 1930. Ч. 7. С. 204-210; Семчишин М. Українознавство та його роля в школі. Учительське Слово. 1939. Ч. 1-2. С. 3-4; Ющишин I.M. Нові наукові програми в народних школах. Методика і шкільна практика: Додаток до часопису «Шлях виховання й навчання». 1933. С. 133-136.

20 Резолюції і постанови Першого Українського Педагогічного Конгресу. Периий Украӥнський Педагогічний Конгрес у Львові (1935). Львів, 1938. С. 236-249.

${ }^{21}$ Куцій М. Естетичне виховання. Шлях навчання і виховання. 1928. Ч. 1. С. 19.
} 
school $^{22}$. Petro Parashchyn agreed with him, as he saw the greatest value of every nation in people who possess a strong character, a solid foundation on which "one can safely build a better future not only for individual units but also for the whole nation" 23 .

The school of post-war Europe was given the task of creating a new type of a person capable of living in a democratic society. Educators in Eastern Galicia were familiar with the views of foreign scholars and were aware of their relevance and importance in the education of young Galicians. In this regard, Ivan Yushchyshyn wrote: "Through the efforts of the world's most popular theorists and practitioners of education, contemporary pedagogy has put one indispensable thesis at the head of educational ideals as a condition for rational human development, and that is activity and creativity! Taking this motto as a basis of their activity, modern educators have strongly criticized the old school of passivism and verbalism, the idea of which was opposite to that of school of work where pupils are given complete freedom to express their activity and creativity" 24 . Similar views were shared by Hryhoriy Terletskyi, who believed that in order to effectively assimilate values, the pupil must be active, independent and creative ${ }^{25}$. Ostap Makarushka saw the purpose of education in the creation of a noble character guided by moral principles and aware of their belonging to the community. "A person of such a noble nature will live not only for their own well-being, but for the well-being of the ones surrounding them. Therefore, they will conscientiously and justly fulfill their duties towards their loved ones." In this case, the teacher considered independence as an important feature that must be formed in the pupil ${ }^{26}$.

The physical and valeological upbringing of the younger generation was no less important in the interwar period. Recognizing health as the greatest treasure of the nation, Olha Makarushka-Terpyliakova

\footnotetext{
${ }^{22}$ Біланюк П. Не лише вчимо, але й виховуємо. Рідна школа. 1936. Ч. 20. С. 293-296.

${ }^{23}$ Паращин П. Дайте дітям характер. Рідна школа. 1936. Ч. 4. С. 75.

${ }^{24}$ Ющишин І. Драматизація в школі. Шлях виховання й навчання. 1927. № 9. С. 10.

25 Терлецький Г. Виховне навчання. Львів, 1939. 19 с.

${ }^{26}$ Макарушка О. Наука вихованя : [підручник для шкіл і родин]. Львів : Накладом автора, 1922. С. 4.
} 
acknowledged a great need to educate citizens about the understanding of "the weight of good health" in the essay "The Importance of Public Hygiene" 27 . This task was emphasized both in educational campaigns and in physical education of children and youth. Educators and public figures in Galicia were well aware of its importance for the comprehensive development of the individual, in particular for national and educational character. Taras Franko was convinced that only exercise can bring up a new and strong generation, because it helps youth to form "organizational sense, calls for division of labor, responsibility for the embraced task, conscientiousness and accuracy, mastering the right effort and belief in own forces... It maintains harmony between mind and body, produces courage, willpower and speed of orientation" ${ }^{\text {"28 }}$.

However, educators have warned that educational work is often leveled by other factors, including the media. Extremely relevant are the words of Myron Fedusevych, written in 1939, about how difficult it is to educate the younger generation in a situation where the school seeks to instill in them such virtues as altruism and obedience while the real life gives examples of the triumph of the fist, cunning and power ${ }^{29}$.

According to Galician educators, namely Ivan Velyhorskyi, Yaroslav Kuzmiv and Myroslav Semchyshyn, in such a contradictory situation the goal of education can be fully realized only by the efforts of the school. According to Ivan Yushchyshyn, the school achieves its goals through its basic ideological direction, the highest spirit and the teaching of different subjects ${ }^{30}$. Thus, Ivan Velyhorskyi wrote: "The road to this goal is a school of work, an active school that teaches young people not only with words, but also gives them a meaning and teaches them to create the meaning of their own lives for themselves." Furthermore, the author elaborated on the content of Ukrainian studies education which, in his opinion, should

\footnotetext{
${ }^{27}$ ЦДІАЛ. Ф. 319. Оп. 1. Спр. 104. Матеріали про діяльність гігієнічної секції товариства, програми курсів, доповіді, листи та ін., 1939 р. Арк. 19.

${ }_{28}$ Франко Т. Історія та теорія руханки. Коломия - Львів : накладом Сокола-Батька, 1923. С. 119.

${ }^{29}$ Федусевич М. За нові українські читанки для гімназій і ліцеїв. Украйнська Школа. 1939. Ч. 1. № 6. С. $30-46$.

${ }^{30}$ Ющишин I. Середовище й програми навчання в народніх школах. Методика і шкільна практика: додаток до часопису «Шлях виховання й навчання». 1933. С. 159-182.
} 
include native language, literature, language history, folklore, ethnology, ethnography, archeology, folk poetry and art (music, painting, architecture), national law, beliefs, paleography, etc. ${ }^{31}$. Yaroslav Kuzmiv also included the modern life of the nation under conditions created by nature (partly by human labor and other influences) in the content of education $^{32}$. Having determined the didactic and educational purpose of Ukrainian studies, Myroslav Semchyshyn noted that mastering the basics of native culture by youth contributes to the formation of respect and love for everything that is native and familiar. When getting acquainted with their native language, the youth learn to appreciate it and to honor it "as the language of their national group". Knowledge of native literature enables pupils to learn about the lives and deeds of past generations and to find examples worthy of imitation. Geography makes it possible to cultivate love for the native land and its riches, and "to mentally connect with it as the foremother of the nation." History brings the youth closer to the past generations and reveals the glorious deeds and exploits of their ancestors ${ }^{33}$.

Educators Yaroslav Kuzmiv and Vasyl Pachovskyi also outlined the requirements that a school as an educational institution must meet: 1) to provide a comprehensive choice of national cultural values; 2) the whole life of the school must be imbued with the national spirit; 3) methods of education and training in schools should correspond to the psychological characteristics of children and the needs of the nation; 4) teachers should be of the same nationality as the students ${ }^{34}$ and be the bearers of national values and mental traits. They are obliged to always remember that they fulfill the mission of the apostles, because, in creating new people, they form a family, city, citizenship, nation through their pupils ${ }^{35}$.

The views of the brothers Bohdan and Kornylo Zaklynskyi are a striking example of Western Ukrainian pedagogical thought. Having made

\footnotetext{
${ }_{31}^{31}$ Велигорський І. Українознавство. Украӥнська школа. 1934. Ч. 19. С. 2-15.

32 Кузьмів Я. Напрямні національного виховання. Перший Украйнський Педагогічний Конгрес у Львові (1935). Львів, 1938. С. 191-194.

${ }_{33}$ Семчишин М. Українознавство та його роля в школі. Учительське Слово. 1939. Ч. 1-2. С. 3-4.

${ }_{34}^{34}$ Кузьмів Я. Напрямні національного виховання. Перший Украйнський Педагогічний Конгрес у Львові (1935). Львів, 1938. С. 191-194.

35 Пачовський В. Українознавство у вихованні молоді. Перший Украӥнський Педагогічний Конгрес у Львові (1935). Львів, 1938. С. 113.
} 
a major contribution not only to folkloristics, ethnography, literary studies and literature, but also to pedagogy, they were highly educated, erudite and had a wide range of interests. The Zaklynskyi brothers have proven themselves to be talented teachers and were the authors of pedagogical works that have not lost their relevance today.

Like the other Zaklynskyi brothers (there were eight of them), they were heavily influenced by family upbringing and the atmosphere of a family hearth. Their father Roman Zaklynskyi (1832-1931) was a writer, literary critic, educator, cultural and educational figure. Bohdan and Kornylo Zaklynskyi followed in their father's footsteps. Having been educated at the Stanislav Gymnasium and Teacher's Seminary, Bohdan Zaklynskyi (1886-1946) worked in the section of the Ukrainian National Cultural Council in Vienna, was a teacher in public schools of Transcarpathian Ukraine (which at the time was a part of the Czechoslovak Republic) and private Ukrainian educational institutions of Galicia. In particular, he taught in such settlements of Transcarpathia as Turi Remety, Dubrynychi, Zarichiv, Velykyi Bychkiv and Yasinya. Upon returning to Galicia, he worked in Zolochiv, Lviv and the village of Medvedivka in Ternopil region.

Bohdan Zaklynskyi was an author of more than a hundred scientific articles, brochures, textbooks and handbooks. Among the most popular of them are The Ukrainian Primer (1916), A Primer for Courteous Children (1917), National Education (1927), An Active School (1927), and Education of Leaders (1928). The titles of these works speak for themselves. A prominent place in the upbringing of the younger generation was assigned by the educator to the formation of nationally conscious, active personality who would be able to lead others. "In times of great changes in our national life, the greatest task of education is to train the young Ukrainian generation to be able to serve the liberation and reconstruction of their native land"36. Only the younger generation is

\footnotetext{
${ }^{36}$ ЦДАВО України. Ф. 3896. Оп. 1. Спр. 3. Рукописи статей «Коломийковський віночок», «Йосип Пешик», доповіді «Дитяча книжка», прочитаної на сходинах вчительсько-педагогічного гуртка міської школи в Рахові 1925 р. тощо. Арк. 26.
} 
capable of fulfilling the task of Ukrainian national construction, and therefore, of course, its upbringing is the most important thing and a necessity.

Bohdan Zaklynskyi was convinced that "the future of our nation lies in the good and national upbringing of children"37. At the same time, he considered it advisable to take foreign experience (of which he was well aware) into consideration. As an example, he cited the particularities of the practice of educating a citizen in Western Europe. "And now the West is turning to the education that is set to awaken the great impulses of admiration and readiness for personal sacrifices which have been sleeping inside the human soul. They are looking for new roads in education to fight the domination of individual will with personal pretense and to make others cherish the foundations of collective will",38.

An example of sacrifice for the sake of own nation is found in the biography of Bohdan Zaklynskyi himself. At the beginning of World War I, he and his five brothers joined the Legion of Ukrainian Sich Riflemen. Therefore, the following lines from his work "What Should Every Ukrainian Know?"39 can be considered the motto of the author himself: "Giving your life for your own nation is the highest merit a person can obtain...". That is why "the greatest honor belongs to these heroes!". Apparently, due to the life circumstances of Bohdan Zaklynskyi himself, the Western European experience was close and clear to him.

Therefore, it becomes clear how important for the scientist was the formation of a nationally conscious citizen, a patriot. He pointed out that "patriotism is a genuine love for your own nation and your native land. And the patriot is an individual who tries to help their nation and works for its well-being with all their strength" ${ }^{\prime 0}$. Thus, the love for the Motherland

\footnotetext{
37 Заклинський Б. Що треба знати кождому українцеви? Відень : накладом «Союза визволення України», у друкарні ад. Гольцгавзена у Відні, 1915. С. 30.

${ }^{38}$ ЦДАВО України. Ф. 3896. Оп. 1. Спр. 3. Рукописи статей «Коломийковський віночок», «Йосип Пешик», доповіді «Дитяча книжка», прочитаної на сходинах вчительсько-педагогічного гуртка міської школи в Рахові 1925 р. тощо. Арк. 28.

39 Заклинський Б. Що треба знати кождому українцеви? Відень : накладом «Союза визволення України», у друкарні ад. Гольцгавзена у Відні, 1915. 39 с.

40 Заклинський Б. Що треба знати кождому українцеви? Відень : накладом «Союза визволення України», у друкарні ад. Гольцгавзена у Відні, 1915. С. 26.
} 
must be deedful and manifested not in unfounded phrases, but in constant work for the sake of its good and the good of all its citizens.

The educator organized reading rooms of Prosvita, centers of Native School and Plast associations. According to him, Plast was extremely important in the education of the younger generation, because it was able to bring up active, deedful patriots of their homeland. Bohdan Zaklynskyi described the task of educating children and youth as follows: "Education should be directed primarily towards mobility (activity). Ukrainian youth nowadays must be creative, productive and do great work." Undoubtedly, such a task was resulted by the problems of building a Ukrainian nation and improving all spheres of its life. "All areas of life are in need of new, creative work, so we need to bring up people for whom continuous work is a joy. And there is a lot of it to be done in the cultural, economic and political fields". Recognizing the great educational value of family and public school and believing that "family is the foundation of the nation" 41 , the educator nevertheless thought that Plast played a significant role in the upbringing of such people: "only Plast can prepare capable and mobile people" ${ }^{42}$.

According to Bohdan Zaklynskyi, the realization of these tasks must be done primarily through the cultivation of will, intelligence and morality. "In order to get the kind of mobile people we desperately need, we must pay attention to the cultivation of freedom. This is the most important task of national education" 43 . The development of intelligence and morality is necessary for a young person to set a goal and to pursue it morally.

The effectiveness of Plast's organizing activity is evidenced by the fact that its ideas are firmly rooted in the souls of its students. In particular, the personal fund of the educator, which is kept in the Central State Archive of Supreme Bodies of Power and Government of Ukraine,

\footnotetext{
41 Заклинський Б. Що треба знати кождому українцеви? Відень : накладом «Союза визволення України», у друкарні ад. Гольцгавзена у Відні, 1915. С. 30.

${ }^{42}$ ЦДАВО України. Ф. 3896. Оп. 1. Спр. 3. Рукописи статей «Коломийковський віночок», «Йосип Пешик», доповіді «Дитяча книжка», прочитаної на сходинах вчительсько-педагогічного гуртка міської школи в Рахові 1925 р. тощо. Арк. 47.

43 ЦДАВО України. Ф. 3896. Оп. 1. Спр. 3. Рукописи статей «Коломийковський віночок», «Йосип Пешик», доповіді «Дитяча книжка», прочитаної на сходинах вчительсько-педагогічного гуртка міської школи в Рахові 1925 р. тощо. Арк. 47.
} 
contains letters from former students ${ }^{44}$ sent to Bohdan Zaklynskyi in Yasinya, where he was teaching at the time. Nearly all of them end with the plastonic cry of "SKOB" (Sylno, Krasno, Oberezhno, Bystro), which embodies both characteristic and the motto of the Plast member: strong in body and mind, beautiful in soul, careful in ideas and plans, fast in thought and deeds. It testifies to the importance and relevance of the ideas underlying the organization's activities to the pupils. This is also evidenced by the drawing of the Plast camp presented to the educator by the Plast members, as well as a poem that embodies the ideas he sought to convey to the pupils.

Bohdan Zaklynskyi considered a children's book to be one of the most important means of education. Speaking in 1925 at a meeting of a teacherpedagogical group of a local school in Rakhiv, the educator emphasized that "a children's book gives children and, through them, the whole nation a spiritual development, because it brings up a new generation that is aware of its nationality. So we can see that the future of the people lies in books." Therefore, the speaker tried to outline the values that should be embodied in children's literature: "Let's put beauty, good and truth in our children's books so they could learn to see and understand it" 45 .

Perhaps the best confirmation of the effectiveness of pedagogical activity for every educator is the gratitude of the former pupils and their awareness of the great work that the educator does every day. Bohdan Zaklynskyi had grateful pupils with whom he kept in touch even after finishing working with them. Among the correspondence stored in Bohdan Zaklinsky's fund in the Central State Archive of Supreme Bodies of Power and Government of Ukraine, extremely eloquent is the letter by Gloria, written to the teacher on May 14, 1927 in Yasinya. In the letter we can come across the following lines: "This perseverance and love that is embedded in our peasant hearts comes from our kind tutors who were not

\footnotetext{
44 ЦДАВО України. Ф. 3896. Оп. 1. Спр. 16. Листи від учнів, 25 жовтня 1925 р. - 12 червня 1927 р., 35 арк.

ЦДАВО України. Ф. 3896. Оп. 1. Спр. 3. Рукописи статей «Коломийковський віночок», «Йосип Пешик», доповіді «Дитяча книжка», прочитаної на сходинах вчительсько-педагогічного гуртка міської школи в Рахові 1925 р. тощо. Арк. 1.
} 
ashamed of the poor peasants and enlightened them. To whom should we be grateful? Who tried to enlighten us? You, Professor. You were the one who was not ashamed of us, and we know and remember it well. It was you and this was your job. And so, our father, Professor, as soon as I see your words somewhere, great dedication and love for my people immediately begins to shine through me"46.

Bohdan Zaklynskyi's younger brother Kornylo (1889-1966) received a thorough education. He studied at the Stanislav Gymnasium and later continued his studies at the University of Vienna, Chernivtsi and Lviv, graduating from the Faculty of Philosophy in 1915. Zaklynskyi worked as a teacher in the village of Vashkivtsi in Bukovyna, and from 1920 to 1938 he was a professor at the Berehove Ukrainian Private Gymnasium. Like his older brother, he was an activist of Prosvita and the organizer of the Plast movement.

Kornylo Zaklynskyi's views on the upbringing were in line with the ideas of Bohdan Zaklynskyi. He believed that the leading role in the upbringing of the younger generationwas played by the formation of the national consciousness of Ukrainians, and that the life of a nation lies in meeting its own national, cultural, economic and political needs. National and cultural aspirations should be implemented through the introduction of national studies, school and native language, as well as rights and laws that correspond to the customs and attitudes of the people. This is the only way to ensure the free development of the nation and to create a native culture, science and $\operatorname{art}^{47}$. For this purpose it is necessary to educate conscious Ukrainians and good citizens of their country. According to Kornylo Zaklynskyi, this can only be done in the home school using the native language.

The article "Observations on Practical Classes", which is stored in Kornylo Zaklynskyi's fund in the Central State Archive of Supreme Bodies of Power and Government of Ukraine, is devoted to the seemingly narrow

\footnotetext{
${ }^{46}$ ЦДАВО України. Ф. 3896. Оп. 1. Спр. 16. Листи від учнів, 25 жовтня 1925 р. - 12 червня 1927 р. Арк. 24.

${ }^{47}$ ЦДАВО України. Ф. 4388. Оп. 1. Спр. 1. Статті «Наші політичні, культурні та економічні домагання в Росії» та «Що треба знати кожному українцю», 1915 р. Арк. 2-7.
} 
methodical problem of organizing manual work. However, it expresses the views of the author on the upbringing of the younger generation, which are concerned with the formation of a well-rounded personality, since they cover moral, physical, intellectual, aesthetic and labor education. According to the educator, one of the most important means of education is work: "The best teacher is work, personal ability, amateur activity, this principle of an active school. All students should be given the opportunity to develop and prove themselves for the good of the nation" 48 . Undoubtedly, these words have not lost their relevance today, as well as the educational tasks which Kornylo Zaklynskyi puts before the school and practical classes in particular.

The educator considered creative mental exertion to be the most important task of manual work for children, as it will allow them to accomplish a variety of other tasks, namely:

"We must imbue children with:

1) Conscious attitude to each and every working process.

2) Respect for all creative work, regardless of its content.

3) Development of the will to creativity and ability to translate their ideas into a specific practical form.

4) The development of self-awareness as a necessary useful employee of the children's collective, citizenship, nation, state.

5) Development of abilities and individual traits"

The educator called for the realization of these tasks through the implementation of mental, moral, physical, aesthetic and labor education. At the same time, he is convinced that manual work helps to harmonize all the directions of education. After all, "the development of aesthetic taste, symmetry, systematics, precision, independence in work, love of work is all the merit of manual work. It subconsciously raises the moral value of the child. "However, these are not the only educational opportunities of manual work. While performing various practical tasks, children receive "the opportunity for specific thinking", as exercises "occupy them practically". "While working, children carefully observe everything, think about the details and strengthen their notions... During conversations at manual labor,

\footnotetext{
${ }_{48}^{48}$ ЦДАВО України. Ф. 4388. Оп. 1. Спр. 3. Стаття «Завваги до практичних занять», б/д. Арк. 6.

${ }^{49}$ ЦДАВО України. Ф. 4388. Оп. 1. Спр. 3. Стаття «Завваги до практичних занять», б/д. Арк. 2.
} 
children are more daring while speaking about details, they come to more accurate conclusions, and it helps to master their native language"

In order to provide comprehensive development for ech individual, it is important for the educator to be ready for this kind of work. "The work of educators is not very intensive here, though they only play the role of a friend and advisor to the child. He then uses all the moments that develop the amount of knowledge in the area of each subject, leaving the children freedom and initiative in the choice of activities, because it develops independence" ${ }^{, 51}$.

The educator's ideas certainly sound very modern. Today, the issues of pedagogy of cooperation, the need to provide every child with opportunities for free development, activity and initiative are as relevant as ever. Therefore, the appeal to the heritage of past Ukrainian educators may outline possible ways of solving the current problems of modern pedagogy and practice of education.

Therefore, Kornylo and Bohdan Zaklynskyi's views on the upbringing of the younger generation remain relevant to this day and can serve as a guide for modern educators to improve the national education system. The idea of national upbringing and transference of human values that form the basis of moral education to the younger generation is the cross-cutting theme of all the pedagogical works of educators. Another important aspect of their pedagogical views is the idea of forming an independent creative personality needed by the modern world. In our opinion, this is the main reason why the heritage of Ukrainian educators needs to be deeply researched and adapted to modern realities.

\section{CONCLUSIONS}

Having analyzed the views on the educational ideal of Ukrainian and Polish educators who worked in Western Ukraine during the interwar period, we can conclude that they were developed mostly within the framework of pedagogy of national and civic education, and were based on national, civic and Christian values.

\footnotetext{
${ }_{50}^{50}$ ЦДАВО України. Ф. 4388. Оп. 1. Спр. 3. Стаття «Завваги до практичних занять», б/д. Арк. 1.

${ }^{51}$ ЦДАВО України. Ф. 4388. Оп. 1. Спр. З. Стаття «Завваги до практичних занять», б/д. Арк. 1.
} 
The analysis of the educational values of the interwar period showed their dependence on the stateless position of Ukraine and the aspirations of the Ukrainians for independence, as well as on the development of a large number of directions and trends which characterize the pedagogy of the late nineteenth and early twentieth centuries.

\section{SUMMARY}

The article analyzes the requirements for the educational ideal which have been substantiated in pedagogical works of Western Ukraine during the interwar period. The characteristic of the educational ideal, substantiated by Polish educators, as well as the approaches to the substantiation of the educational ideal by Ukrainian educators, are presented. The political and economic preconditions for crystallization of the educational ideal are characterized. It has been proved that the views on the educational ideal of Ukrainian and Polish educators who worked in Western Ukraine during the interwar period were developed mostly within the framework of pedagogy of national and civic education. They were based on national, civic and Christian values.

The analysis of the educational values of the interwar period showed their dependence on the stateless position of Ukraine and the aspirations of the Ukrainians for independence, as well as on the development of a large number of directions and trends which characterize the pedagogy of the late nineteenth and early twentieth centuries.

\section{REFERENCES}

1. Біланюк П. Не лише вчимо, але й виховуємо. Рідна школа. 1936. Ч. 20. С. 293-296.

2. Велигорський I. Українознавство. Украӥнська школа. 1934. Ч. 19. С. $2-15$.

3. Заклинський Б. Що треба знати кождому українцеви? Відень : накладом «Союза визволення України», у друкарні ад. Гольцгавзена у Відні, 1915. 39 с. 
4. Кузьмів Я. Напрямні національного виховання. Перший Украйнський Педагогічний Конгрес у Львові (1935). Львів, 1938. C. 191-194.

5. Кузьмів Я. Шкільні характеристики учнів. Шлях виховання й навчання. 1930. Ч. 7. С. 204-210.

6. Куцій М. Естетичне виховання. Шлях навчання $i$ виховання. 1928. Ч. 1. С. 19-23.

7. Макарушка О. Наука вихованя : [підручник для шкіл і родин]. Львів : Накладом автора, 1922. 152 с.

8. Маланюк С. Місцеві цінності в скарбниці національного виховання Методика $i$ шкільна практика: Додаток до часопису «Шлях виховання й навчання». 1933. С. 203-211.

9. Паращин П. Дайте дітям характер. Рідна школа. 1936. Ч. 4. C. $72-75$.

10. Пачовський В. Українознавство у вихованні молоді. Перший Украйнський Педагогічний Конгрес у Львові (1935). Львів, 1938. C. 89-113.

11. Резолюції і постанови Першого Українського Педагогічного Конгресу. Перший Украӥнський Педагогічний Конгрес у Львові (1935). Львів, 1938. С. 236-249.

12. Рудницький С. Україна наш рідний край: Коротка географія. Львів, 1921. 128 с.

13. Семчишин М. Українознавство та його роля в школі. Учительське Слово. 1939. Ч. 1-2. С. 3-4.

14. Терлецький Г. Виховне навчання. Львів, 1939. 19 с.

15. Ушинський К. Про народність у громадському вихованні. Вибрані педагогічні твори : у 2-х m. К. : Радянська школа, 1983. Т. 1. C. 43-104.

16. Феделешъ В.И. Учебникъ исторіи Подкарпатской Руси отъ найдавнЂйшихъ временъ до днешнихъ дней и Чехословакіи до XIV. вЂека. Мукачево : Типографія «Карпатія», 1922. 50 с.

17. Федусевич М. За нові українські читанки для гімназій і ліцеїв. Українська Школа. 1939. Ч. 1. № 6. С. 30-46. 
18. Франко Т. Історія та теорія руханки. Коломия - Львів : накладом Сокола-Батька, 1923. 200 с.

19. ЦДАВО України. Ф. 4388. Оп. 1. Спр. 1. Статті «Наші політичні, культурні та економічні домагання в Росії» та «Що треба знати кожному українцю», 1915 р., арк. 2-7.

20. ЦДАВО України. Ф. 4388. Оп. 1. Спр. 3. Стаття «Завваги до практичних занять», б/д, 11 арк.

21. ЦДАВО України. Ф. 3896. Оп. 1. Спр. 16. Листи від учнів, 25 жовтня 1925 р. - 12 червня 1927 р., 35 арк.

22. ЦДАВО України. Ф. 3896. Оп. 1. Спр. 3. Рукописи статей «Коломийковський віночок», «Йосип Пешик», доповіді «Дитяча книжка», прочитаної на сходинах вчительсько-педагогічного гуртка міської школи в Рахові 1925 р. тощо, 266 арк.

23. ЦДАВО України. Ф. 4379. Оп. 1. Спр. 21. Щоденник Боберського I. за 1918 - 1919 рр., 28 серпня 1944 р., 183 арк.

24. ЦДІАЛ. Ф. 319. Оп. 1. Спр. 104. Матеріали про діяльність гігієнічної секції товариства, програми курсів, доповіді, листи та ін., 1939 р., 47 арк.

25. Ющишин I.M. Нові наукові програми в народних школах. Методика $i$ шкільна практика: Додаток до часопису «Шлях виховання й навчання». 1933. С. 133-136.

26. Ющишин I. Колективізм чи індивідуалізм: Завваги до громадівських інстинктів нашого народу. Шлях виховання і навчання. 1930. Ч. 5. С. 129-133.

27. Ющишин I. Драматизація в школі. Шлях виховання $\check{u}$ навчання. 1927. № 9. С. 4-12.

28. Ющишин I. Середовище й програми навчання в народніх школах. Методика і шкільна практика: додаток до часопису “Шлях виховання й навчання". 1933. С. 159-182.

29. Ярема Я. Нова фаза в розвитку європейської школи. Украӥнська Школа. 1934. Річник ХІХ. С. 3-11.

30. Łempicki S. O ideał wychowania w Polsce (Wyniki ankiety). Lwów, 1929. 22 s. 
31. Pannenkowa I. Myśli o wychowaniu narodowem. Lwów : Nakł. "Polskiego T-wa pedagogicznego", 1918.98 s.

32. Pannenkowa I. Nasze zadania wychowawcze. Warszawa, $1929.28 \mathrm{~s}$.

\section{Information about the author:} Nevmerzhytska $O$.

Doctor of Pedagogical Sciences, Associate Professor, Professor at the General Pedagogy and Preschool Education Department,

Drohobych Ivan Franko State Pedagogical University 24, Ivan Franko str., Drohobych, 82100, Ukraine 


\section{PRECONDITIONS AND PRIORITY DIRECTIONS OF THE REFORM OF THE SYSTEM IN NATIONAL HIGHER EDUCATION}

\section{Orshanskiy L.V.}

\section{INTRODUCTION}

With the adoption of the Laws of Ukraine "Education Law" (2017) ${ }^{1}$ and "Higher Education Law" (2014) $)^{2}$, an active process of transformation of this important industry began in the context of European integration processes and prospects. In order to implement a strategic course on the entry of Ukraine into the European educational space, the main directions of educational, scientific and cultural integration have been identified, the mechanisms of implementation of European norms and standards in higher education have been identified, etc. As a result, these areas and mechanisms should work to enhance the European cultural identity of Ukrainians and create a pan-European intellectual and educational environment in Ukraine. However, despite the modern vector of higher education development, which leads to a new sociopolitical paradigm, this branch, unfortunately, does not provide the necessary quality that necessitates its reforming, that is, deliberately regulated improvement and intensification of educational and scientific processes.

With the help of existing statistical data, we will try to analyze the current state and problems of the Ukrainian higher education system, which experienced systemic structural changes, as well as to determine the preconditions and priority directions of the reform of the system in national higher education.

\footnotetext{
1 Про освіту: Закон України від 05.09.2017 р.№ 2145-VIII. URL : http://zakon.rada.gov.ua/laws/ show/2145-1

2 Про вищу освіту. Закон України № 1556-VII від 01.07.2014. URL : http://zakon4.rada.gov.ua/laws/ show/1556-18
} 


\section{Current state of higher education in Ukraine and the problems of its reformation}

According to the State Statistics Service of Ukraine ${ }^{3}$, since the 1990s, there has been a steady increase in the number of institutions of higher education (HEI). So, if in 1991-1992 the year in Ukraine there were 742 institutions of secondary specialized and vocational education and 149 HEI, then in the "peak" 2006-2007 there were 570 colleges, technical schools, colleges, lyceums and 350 universities, academies, institutes. Therefore, the number of HEI of I - II levels of accreditation, for the last 16 years, decreased by 172 establishments $(23,2 \%)$, while the number of HEI of III - IV accreditation levels increased by 201 (235\%).

Before putting "Higher Education" law into action, on August 1st, 2014, in Ukraine, there were generally 803 state, communal, joint-stock, and private self-employed I - IV accreditation levels, among which: 198 universities, 62 academies, 83 institutes, 245 colleges, 97 technical schools, 117 vocational schools and 1 conservatory (Fig. 1). The Ministry of Education and Science in 2014 transferred from the higher vocational class to more than one hundred educational institutions. At the beginning of 2016 in Ukraine there are about 659 HEI (371 establishments of education of the I - II levels of accreditation, 288 - III - IV accreditation levels) and their further optimization (branch reduction, consolidation, etc.) is carried out.

A significant demand for prestigious university education in the first place has created a paradoxical situation when, against the backdrop of the socio-economic crisis of the mid-1990s, a sharp decline in the population and the closure of industrial enterprises that needed skilled workers and engineers, the number of students studied at the HEI of different levels of accreditation has increased almost three times: from 1638,3 thousand people in 1990-1991 years up to 2813,8 thousand in 2007-2008 year. Then there was a sharp decrease in the number of students, which is related exclusively to demographic and socio-economic problems. At present, 1605,300 students study at the I - IV levels of accreditation (Fig. 2).

\footnotetext{
3 Державна служба статистики України : Вищі навчальні заклади. URL : http://www.ukrstat.gov.ua/ operativ/operativ2005/osv_rik/osv_u/vuz_u.html
} 


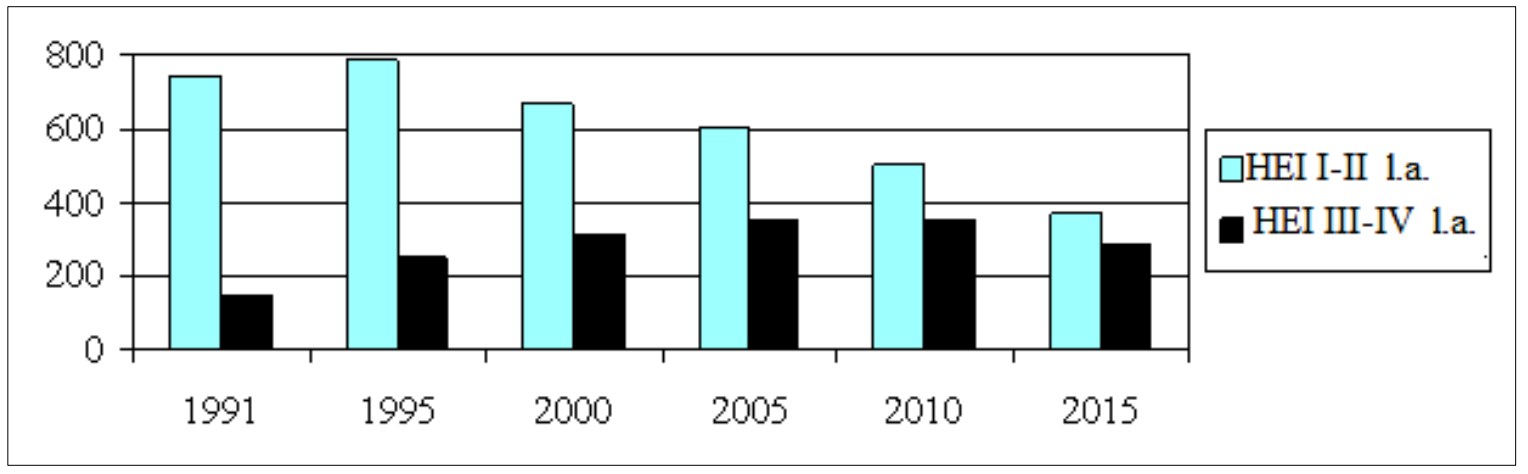

Fig.1 The number of educational institutions

I-V levels of accreditation in UA

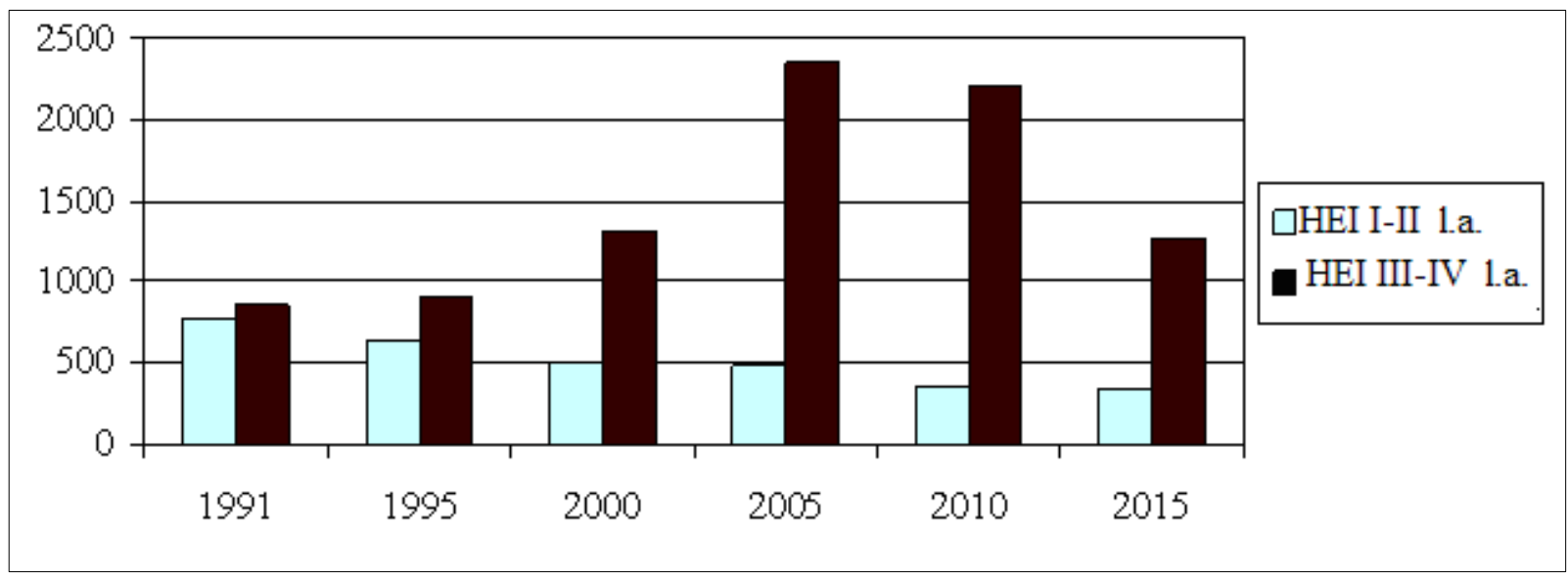

Fig. 2. The number of students belonged to educational institutions I-IV of accreditation

So, nowadays the number of vocational education institutions has decreased by half from 742 to 371, whilst the number of universities and other types of HEI in the past 25 years has increased by $193 \%$. Such an uncontrolled increase in the number of HEIs, as well as the demographic challenge of Ukrainian society, led to the proportionality of the number of educational places in higher educational institutions and the number of graduates of secondary schools (Fig. 3). There was a total transition to a massive, universally accessible higher education, which for citizens, supposedly, was a "mandatory attribute". Beginning from 2006-2007 the number of enrolled students almost every year exceeded the number of those who in the same year completed secondary education. That is, 
consecutive for the ninth year, starting in 2007, university education in Ukraine has become a kind of continuation of the school, one of the mechanisms of social protection of youth. This could be seen as a positive fact, if not a number of circumstances of great concern.

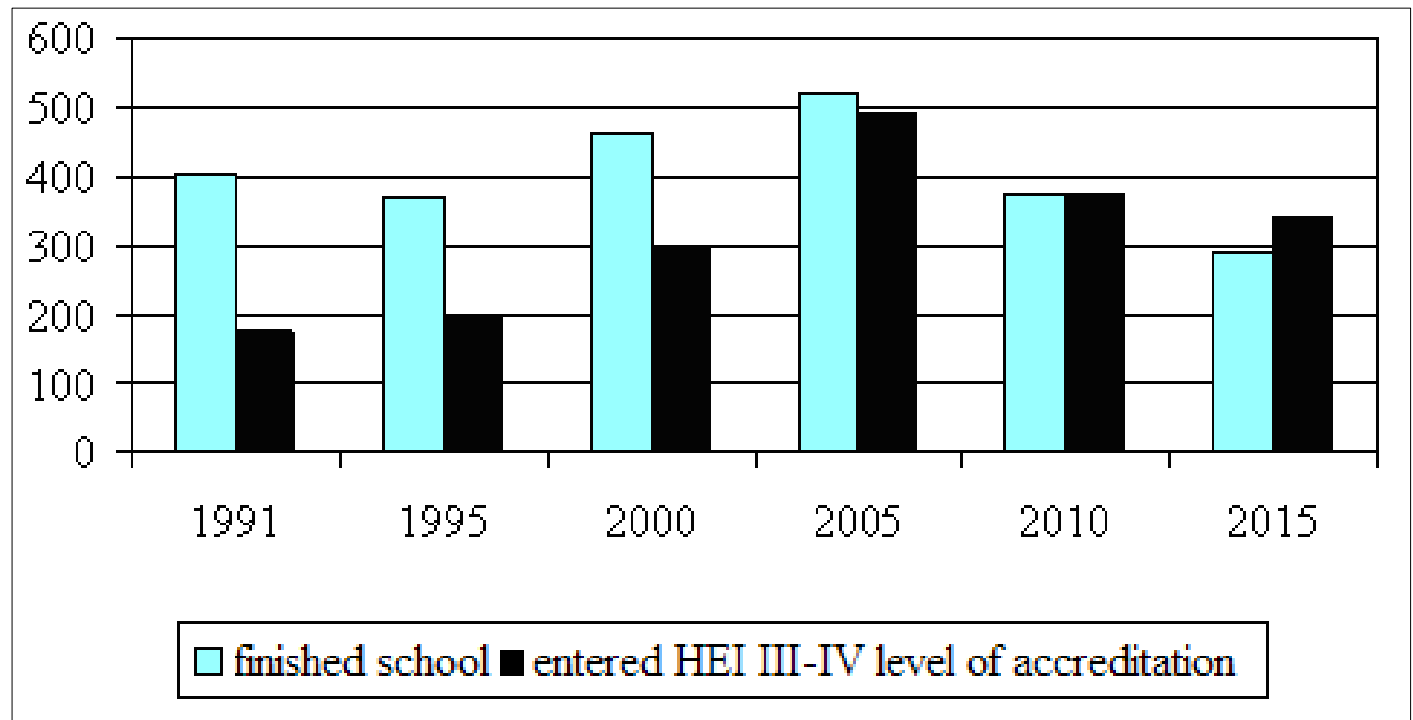

Fig. 3 The number of students of schools who received certificates of full secondary education and students who entered HEI

Most national HEIs created during the period of uncontrolled growth, do not have adequate material and technical resources for the qualitative implementation of the educational process, they virtually have no library funds, the state of such educational institutions consists mainly of detached workers, mostly teachers of "neighboring" state institutions or even teachers of secondary schools. About scientific, pedagogical schools, directions of fundamental and applied research, long-term educational traditions in such "universities" language is not discussed at all. Of course, the state granted the right to get profit on education, and nobody canceled it yet, but the requirements for the quality of higher education should be the same for educational institutions of all forms of ownership.

With the transition of society to market relations, institutions of professional and higher education become the subjects of a market economy. In everyday colloquial vocabulary, instead of words "education 
and training" the term "educational services" is increasingly used, and the success of higher education is considered through the prism of market relations, reloaded the fund of development. It should be acknowledge that in the gross value added by Ukraine in 2012, the share of the education sector was $6,2 \%$ (UAH 75,1 billion), twice the share of construction and approaching the indicator of extractive industry. However, the formed structure of these market relations of higher education and society is of some concern. Over the past decade, the proportion of students in stateowned non-state assets, based on contract, has an increased from $21,4 \%$ to $56,2 \%$. This way, in 2013 - 2014 the HEIs of IV - IV accreditation levels, using the state budget funded 750,4 thousand people, local budgets formed - 18,8 thousand people, natural and legal persons - 954,5 thousand people ${ }^{4}$. It is understandable and logical to see the interest of HEI in the students' recruitment based on a contract, as they load up the extrabudgetary fund, creating additional opportunities for decent wages, bonus of scientific and pedagogical workers, infrastructure development, updating of material and technical base, etc. On the other hand, such an increase in interest for recruiting on a paid form of studying leads to a decrease in quality of the students' contingent. While forming educational groups, most universities makes no differentiation of students' groups depending on the form of payment. Taking into an account the substantially lower requirements for students with paid forms of education, one can speak about reducing the working capacity of the academic group as a whole, as well as the motivation and ability to study for each individual student.

Another problem that causes concern to Ukrainian society, which showed a desire to join the EU in the nearest future, is the lack of HEI being prepared for the internationalization of higher education. Although our country joined the Bologna process, which initiated the structural modernization of national higher education systems, putting into practice this did not lead to the effective integration of the home educational system

\footnotetext{
${ }^{4}$ Вища освіта України. Центр міжнародних проектів НДІ прикладних інформаційних технологій «Свро Освіта». URL : http://www.euroosvita. net/prog/print.php/prog/print
} 
into the European scientific and educational space. On the other hand, recently a number of trends in the transformation of specialists in higher education have been implemented, namely: ensuring the transparency of educational programs; creating conditions for comparing educational programs in different universities and in different European countries; implementation of the European Credit Transfer and Transfer System (ECTS) as a basic tool for enrollment of academic disciplines, developed by students at other universities, etc. Yet, it should be acknowledged that the system of academic mobility has not yet begun, which enables students and teachers to "move" from one form of HEI into another one, gaining an access to new quality educational programs, courses, research activities, improve their foreign language skills.

As a result, today there are a number of powerful state "players" capable of competing in the world market of educational services. So, if in the world ranking of the level of general education published by the International Organization for Economic Cooperation and Development, Ukraine in 2015 ranked rather high of 38th place, then according to Quacquarelli Symonds' version, in the ranking of the 1000 best universities in the world (QS World University Rankings) in 2016 only six national universities were included - V.N. Karazin Kharkiv National University (382th place), Taras Shevchenko National University of Kyiv (within the limits of 431-440 places), National Technical University of Ukraine "Igor Sikorsky Kyiv Polytechnic Institute" (within 551-600 places), Donetsk National University, The National Technical University "Kharkiv Polytechnic Institute" and Sumy State University (below 701 places). This doesn't mean strengthening the position of Ukraine in the international market of educational services, but on the contrary - the loss of positions on its own national market, due to the desire of young people to immediately study in prestigious higher education of other states. For example, in 2015, more than 20,000 university entrants went to study in Poland; more than half of Ukrainians with higher education do not work according to their specialty, and every third graduate changes his/her profession immediately after 
graduating. Today in Ukraine there are officially about 1.8 million unemployed, more than $80 \%$ of them are specialists with higher education.

Another consequence of a spontaneous formation of the market educational services is unjustifiably high graduation figure of specialists in socio-economic and humanitarian fields. Students' contingent analysis doesn't demonstrate the choice in favor of social, pedagogical, agrarian, engineering or natural sciences, which in its turn lays the foundation of innovation development of industry and society. There is an abundance of "office" workers whilst the apparent shortage of workers, providing a "meaningful" component of home economy. An irony is popular a popular saying that soon managers will have no one to administer, and there will be none left who needs lawyers' defense.

Today, considering relatively young economy market of Ukraine, there is no effective and efficient mutual regulation of queries and offers of labor markets and educational services. This, of course, can not but affect the situation in the field of employment. It seems that nowadays, choosing training in the areas of "Humanities", "Management", "Jurisprudence" and others, entrants and their parents in advance "reserve" a place in the queue at the employment centers. Therefore, special efforts of the state are required to streamline the structure of the directions of training specialists, its harmonization with the needs of the economy and society. Such measures are impossible without a broad vocational guidance work aimed at shaping the needs of a young person to realize their potential in the field of promising areas of production and services that are characterized by the innovative nature of development.

Modern innovative economy, based on high technologies and intellectual work, requires specialists with different levels of competence, which is being prepared within the framework of graduate education. The introduction of a three-tier system of higher education (bachelor, master, doctor of philosophy) provides conceptually new approaches to the formation of the content of education, the application of productive didactic methods and technologies for the organization, implementation and quality control of education, the introduction of components of the 
innovative educational model. It is possible to discuss the appropriateness of certain actions of the state, but the transition to multi-level higher education is a systemic action with far-reaching consequences for the educational sector and the country as a whole, given the European integration hopes. Therefore, the responsibility for the correctness and timeliness of the steps taken by the state, HEI and each of its scientific and pedagogical worker is extremely high.

Obviously, one of the most important factors in the effective functioning of higher education, its successful reformation is providing qualified staff workers. Today, the situation in this area is also quite wellfounded under the concern. According to statistics for 2013-2014 the number of scientific and pedagogical workers of the III-IV level of accreditation was 158,9 thousand people, including more than 71,4 thousands of candidates of sciences and 14,4 thousands of doctors of science, 48 thousands of docents and 12,7 thousands of professors ${ }^{5}$. The analysis of statistical data shows that the increased volume of educational services provided by the higher school is supported practically by the same number of teaching staff as at the end of the twentieth century. Significantly was increased the number of students, who belonged to the unit of scientific and pedagogical staff of scientists with degrees of candidates and doctors of sciences. Although the number of professors' teaching staff of the Defense Forces of Ukraine, which received academic degrees and titles, has increased significantly, at the same time, their average age has increased as well. In this context, it is worth paying attention to the statistical study of quantitative and qualitative indicators of the professors' teaching staff, conducted by A. Makarenko. According to the statistics provided by it, the largest number of teachers having a degree is between the age of 51 and 60 years old. In particular, in 2010, the average age of instructors was 45,7 years old, which is with $26,2 \%$ of faculty graduates reaching middle aged over 50 years old. The average age of candidates of sciences, associate professors working on the positions of the heads of

\footnotetext{
5 Вища освіта України. Центр міжнародних проектів НДІ прикладних інформаційних технологій «Євро Освіта». URL : http://www.euroosvita. net/prog/print.php/prog/print
} 
departments, reached 48,9 years old, and doctors of sciences, professors 56,5 years old $^{6}$. The situation with the middle age of scientific and pedagogical workers has changed only in the direction of its increase over the last two years. This is a rather alarming signal, as it shows the lack of influx of creative young people in the educational sector, the loss of motivation for scientific and pedagogical activity.

The next problem of today's higher education is the insufficient level of personnel reserve due primarily to low wages. According to the State Statistics Service, education is in the top five lowest paid state industries ${ }^{7}$. Thus, the average salary in education in August 2015 amounted to $3542 \mathrm{UAH}^{8}$, which at that time amounted to about \$130. At the same time, it should be pointed out that although the government tried to solve this problem by raising salaries to teachers in 2017 by $50 \%$ and another try by $25 \%$ - in 2018 , however, inflationary processes in the economy virtually dampened these efforts. As for university teachers, over the last past 5 years, their salaries have been raised by $20 \%$ only in early 2019 . Instead, according to an expert survey entitled "The Right to Education and Education Rights" of the European Research Association, conducted with the company InMind in June 2018, where 32\% of teachers performed free overtime work, and $44 \%$ of instructors had experience in exceeding the maximum academic, scientific and methodological load ${ }^{9}$. Obviously, a young teacher who has a difficult path to an associate professor or professor still has to go through, solving a number of home problems (buying housing, creating and maintaining a young family, etc.), such income levels and increased demands become unattractive.

Another important issue of higher education is the multiple employment of a teacher, which is implemented in a variety of forms: a

\footnotetext{
${ }^{6}$ Макаренко А. Ю. Кадровий аспект проблеми формування ІКТ-компетентності викладачів ЗВО. Наукова скарбниия освіти Донеччини. 2013. № 1 (14). С. 85.

7 Державна служба статистики України : Вищі навчальні заклади. URL : http://www.ukrstat.gov.ua/ operativ/operativ2005/osv_rik/osv_u/vuz_u.html

8 Зарплата українських вчителів - одна 3 найнижчих у світі URL : http://www.unian.ua/society/838832zarplata-ukrajinskih-vchiteliv-odna-z-naynijchih-u-sviti.html

${ }^{9}$ Право на освіту та права освітян: теорія і практика в Україні: аналітичний звіт за результатами громадського моніторингу. URL : http://eura.org.ua/ wp-content/uploads/2010/01/ERA_Vidrodzhannya_ Право-на-освіту-та-права-освітян_Аналітичний-звіт_-червень-2018.pdf
} 
combination of work in several universities and the simultaneous conduct of numerous courses, tutoring, scientific and practical activities. Such activities as many others are not related to their profession, but have become for teachers a source of additional income, even sometimes - the main source income. The multiple work of the teacher, the long work over legislative norms depletes, leads to psychological overloads, increase in the cost of teaching work, which are not compensated by the appropriate remuneration. As a result, the motivation and quality of the teacher's work decreases at their main place of work in which is HEI. This state of affairs testifies to the low level of prestige of scientific and pedagogical activity of our society. Reducing the motivation of young scientists to come to the educational sector with a low pay for a teaching job inevitably affects the number and quality of the contingent of applicants enrolled in the specialties that serve this public sector of the economy.

The following prerequisites should be created to solve the above mentioned problems and to successfully reform in higher education:

- firstly, the high level of development of pedagogical science, the formation of the psycho-pedagogical community, its interaction with representatives of related sciences, the humanistic nature and practical orientation of state educational thought, its orientation towards ensuring the unity of education, education and development;

- secondly, the development of scientific research in high school, the successful methodology of training scientific and pedagogical staff, the existence of justified forms of integration of educational and scientific processes;

- thirdly, the application in domestic higher education of effective innovations in the content, methodological and organizational nature, as well as the fundamental possibility of their dissemination through statetargeted programs and training system of scientific and pedagogical workers and university managers. 
Based on the analysis of normative legal materials, literary sources, statistical data and practical experience, we have identified the priority directions of the reform of the national university education:

1)ensuring equal opportunities for obtaining high-quality higher education by different groups of the population;

2) improvement of the educational environment, creation of proper conditions for education at all levels;

3) practical implementation of the idea of "learning throughout life";

4) decentralization of the system of higher education and providing real autonomy of HEI;

5) optimization of the state order for the training of specialists with higher education in accordance with the real needs of the state and private sectors of the national economy;

6) implementation of the principle of student-centered learning;

7) sustainable integration of training and research;

8)further internationalization and deepening the mobility in educational and research activities;

9) extending the rights, freedoms and autonomy of universities;

10)implementation of cooperation in the system "university production";

11)quality control of higher education according to European level;

12)decent wages and social protection of scientific and pedagogical workers.

13) the possibility of diverse student and teacher's development;

14)improvement of the mechanisms and infrastructure for raising professional skills and teaching staff retraining;

15)the creation of advanced educational and methodological support of modern material and technical base.

\section{The basic principles of the University's innovative educational policy}

Today the essence of the University's educational policy is to provide these fundamental directions in a clear and transparent form for all 
scientific and pedagogical workers: as a set of tasks, coordinated from all kinds of resources and mechanisms, while giving the freedom of choice for teachers and the administration to perform actions for the implementation of new ideas. It should be borne in mind that reforming the educational sector, improving the educational policy can only be achieved by involving as many as possible experienced teachers, managers and active students in this process, which requires the development of a certain corporate culture and fundamentally new thinking.

To form such thinking among the entire staff of the University in order to achieve the goal is one of the main objectives of innovative educational policy, which is developed on the basis of the unified basic principles proposed by V. Astakhova ${ }^{10}$ :

1. The principle of social determination - requires, first and foremost, awareness of each subject of the educational process of the main social tasks put forward by society and the state at the given historical moment before the system of higher education. Only based on this it is possible to define a specific niche of the university, its strategic and tactical tasks, the content of educational activities, forms and methods of organization of educational work.

2. The principle of social partnership - involves a radical change in the functional characteristics and target directions of education, the formation of a new system of relations between government, business, students, parents, employers and educational institutions, which will enhance the quality of professional training.

Unfortunately, social partnership is currently only being formed, therefore, it does not reveal systemic character and requires comprehensive study and testing of implementation mechanisms. However, some of its trends are already quite clear. For example, the transition from the formalcompulsory model of relationships between partners in the system of higher education to the initiative-humanistic, oriented towards the

\footnotetext{
10 Астахова В.I. Розробка нової освітньої політики як найважливіша умова модернізації сучасної освіти. Вісник Харківського національного університету імені В.Н. Каразіна. 2016. ВиП. 37. С. $204-212$.
} 
coordination of goals and interests, valuable orientations and partners' needs.

3. The principle of humanization and psychology of the HEI's activity is based on the paradigm of student-centered, humanistic outlook and respect for the personality of all participants in the educational process. In accordance with this principle, the student is considered not as a means of goals implementation, but as the ultimate aim to achieve all these what university is for. At the same time, this very principle is the most important means for reaching the final result of educational activities. Hence, the main condition for the University's successful activities is the individualization of training, the development of methods of individual work in order to maximize the disclosure of personal qualities and potential opportunities of each student. This principle requires the implementation of existing laws and norms of morality, respect for the traditions of the native Alma mater, psychological competence and intelligence of all heads of educational units, teachers, teaching auxiliary staff, students.

Unfortunately, in the majority of scientific and pedagogical workers there is insufficient experience of humanistic communication, active participation in management, personal responsibility for the results of collective labor, where difficulties arise from, in solving many problems facing the university. The pedagogy of partnership, cooperation, mutual understanding and trust, mutual respect and interaction of all participants in the educational process should be the cornerstone of the implementation of this principle.

4. Step by step principle, the principle of continuity and promise - is connected with universal Hegelian laws that are manifested in all spheres of society's life, and is based on the unconditional necessity to analyze and make the most of the legacy of the past, the experience of the present, real possibilities and prospects for the future.

Today there is no doubt that the future system of university education needs a radical revision of most ideas about traditional educational practices, which corresponded to the social order of the era of industrial 
society - the preparation of a highly skilled person, a professional in a particular field of work. The content of education, where the main idea was the knowledge of the world and its subordination to the causal relationships that open up to a person in knowledge suitable for solving problems in standard situations, now contradicts the conditions of dynamism, instability and ambiguity of the world. The search for new models, oriented on creativity, acquisition of knowledge activity and the upbringing of high moral principles, become the actual tasks of practice and modern science.

Implementation of the concept of continuous education - one of the most effective ways of forming competent professionals capable of withstanding competition on the labor market. It is the continuous education designed to ensure the harmonious development of the student's individual, to individualize the educational process, to raise the conscious need of each student in raising the level of their competencies. An important feature of continuous education is its orientation towards the future, in solving problems of the development of society through the formation of professional and general cultural competence in the process of learning.

5. Principle of competence and participation in scientific activity. One of the most important requirements of the new paradigm of education is the orientation towards the education of self-esteem and freedom, the formation and development of professional and general cultural competencies. This leads to the transformation of content, the change of methods, tools and organizational forms of the educational process, and especially the revision of the values of education as a social and cultural phenomenon.

New situation has qualitatively changed the essence of professional competence. The emphasis has shifted from the substantive (technological) knowledge and skills used in solving operational tasks in the direction of conceptual, poly-professional skills and skills that enable them to realize strategic objectives and successfully incorporate into the development of innovations. An important professional competence was the ability to act 
in extreme, stressful, non-standard situations. Thus, professional competence has become more autonomous in relation to specific demands of the labor market. At the same time, the range of competences that "serve" professional competence and non-professional life of a person has expanded: communicative, social, economic, discursive and other competencies, are closely interconnected. Communicative competence as extra functional earns a particular importance, the role of auto-competence increases, therefore, the availability of adequate ideas about oneself, their qualities, abilities, goals and motives of activity grows. This means that the content and process of learning should be aimed at the formation of each student's abilities and qualities that guarantee the susceptibility to everything new, cause the internal need to continually deepen their culturally and professional knowledge, set learning for life, be able to adequately respond to professional problems and life situations. The new economy forces us to give up narrow specialization in favor of interdisciplinary knowledge and versatile competencies. The labor market requires professionals who can quickly transform themselves, make the right decisions and work effectively in a multicultural environment.

Higher education is not only a process of acquiring and assimilated information on a specialty, students need to be taught to think, to learn to study. This requires classroom classes and personal contacts between students and the faculty. However, in order to provide a competent approach to student learning, the teacher must possess the necessary competences himself, which, unfortunately, does not always take place in educational practice.

The professionalism of the teaching staff, their readiness for scientific and pedagogical activities involves the effective possession of the three main competencies: scientific subject, psychological and pedagogical and social and humanitarian. The teacher's transition from performing the functions of the translator of knowledge to the functions of the organizer, the inspirer, the coordinator, the tutor presupposes the formation of the relevant professional qualities and the professional-pedagogical position, which is based on understanding the goals of modern higher education, the 
mechanisms of professional and personal development, and methods of pedagogical management. As one of the main factors of the success of the reform is the commitment and attraction of scientific and pedagogical workers, their personal interest in the new results of their work is necessary. Given the fact that in the coming decades the competitive advantages of developed countries and regions will provide a paradigm of human development, an important condition for achieving results is the humanistic outlook of teachers, the belief in human capacity, the possession of personally oriented technologies for managing the professional development of students. In connection with this, the requirements for the research activities of teachers, the functioning of scientific schools are increasing, and interest in broad involvement in the teaching of scientists working in the research structures, leading specialists from different fields of production and business is growing. Innovative educational process involves the active participation of students in research work. World experience shows that any attempts to provide a high-quality educational process without the development of scientific research is doomed to failure, as it limits the creative possibilities of both teachers and students, leads to self-restraint and stagnation.

6. The principle of collectivism and team work - ensures the creation of the unique atmosphere of mutual understanding and cooperation, mutual support and interest in the success of each other, which is inherent in the family relationship of unity, warmth and attention to each member of the family. Formation of a co-thinker group, people who work in the field of achieving a single goal does not in any way imply a leveling of bright personalities among teachers and students. On the contrary, this process is impossible without stimulating the interested creative activity of everyone, without creating the maximum conditions for their development, material and moral stimulation of the creative work of the individual in the name of establishing the credibility of the entire labor collective. Therefore, among the main priorities for the future, it is necessary to focus on working with the most gifted and motivated students, developing their individual educational trajectories, special programs, creative tasks. 
Based on collectivist principles, patriotism is actively formed as a loyalty to the ideals and traditions of the higher, as the trembling attitude to university symbols (emblem, flag, anthem, memorable signs, etc.), as the willingness to come to the aid of each other and the collective as a whole in any situation. Collectivism is the result of purposeful educational work of educational and extra-curricular units of HEI.

7. Principle of creative learning. By building a model of higher education for an innovative economy, experts point out that "the culture of assimilation should be replaced by a culture of search and renewal"11. In other words, modern trends require the redistribution of the proportion of used teaching methods, oriented towards students' reproductive, productive, creative and researching activities. Educational technologies that allow the training of highly skilled professionals capable of creativity are based on the inclusion in the educational process of elements of research, close to the actual activities of a future specialist. For organization of the learning process in the HEI, as in the business sector, it is important to disseminate project forms of work that can be applied not only within the framework of individual training sessions, but also in the mode of mobile project groups. Thus, the principle of creative learning involves the productivity of cognitive students' activity, the production of subjective and objectively new knowledge, technologies, etc., joint creative search, the use of interactive and project methods, as well as the context of learning, that is, imitating the solution of real professional problems.

8. Principle of activation of personal mechanisms of professional formation. An important requirement for the educational process is the consistent stimulation of the personal development of each student, the activation of the personal mechanisms of his professional development. Since the qualities of a competent professional can not be formulated from the outside and in a step-by-step controlled work, a high level of student autonomy is required, support for self-determination of the student in relation to the work being carried out and self-actualization in it. A student

\footnotetext{
${ }^{11}$ Терлоу К. Образование в перспективе. Первое сентября. 2012. 24 ноября. С. 1.
} 
as a person and a future professional develops only in that activity, which is stimulated by internal motives, carried out with curiosity and enthusiasm. In this case, he shows his potential, improves the ability to manage himself and his activities, achieve planned results. It is no coincidence that the student's motivation, interest, and abilities are considered to be the key, most valuable resource of education. It is this case a personal resource which allows "to run" the mechanisms of professional development, gives the most value, in terms of innovation economy, educational outcomes.

9. Principle of problem-oriented approach for management activities. Describing the modern management model one must take into an account that the university is a quite specific type of educational institution, the results of which depends not only on the formal features management system (legal form, structure, documentation, etc.), But the system of values which are promoted under this team, where the management activity relies on. Non standard, problem existing in education, the necessity to search for non-trivial ways of their solution is determined by the rejection of the principles of classical theory and the transition to professional management, based on the modern theoretical basis, a new management paradigm. One of the peculiarities of this paradigm is standing by from managerial rationalism - the initial belief that the success of any organization (including HEI) is determined primarily by a rational organization, a clear division of functional responsibilities, the efficient use of all kinds of resources. Under such a traditional approach, any organization is considered to be a "closed" system whose goals and objectives are presumed to be predetermined and remained, as well as other conditions of activity, sufficiently stable over a long period of time. The basis of the strategy of such organizations is the continuous growth, increase of quantitative indicators, while in the mechanisms of management, the effective control of all types of activities is crucial. The new philosophy of management is based on system and situational approaches. Any HEI is seen as an open system: the main reasons for its success are not inside but outside of it. The success is associated with how 
well the university adapts to the external environment: economic, scientific and technical, socio-political, cultural, etc. This determines the need for a situational approach, according to which the construction of the control system is nothing but the organization's response to the various external influences by nature and some other characteristics of its organizational context, in particular, the dependence on the quality of human resources. The new situation in the world, especially in the field of higher education, today depends on two factors: uncertainty and orientation towards the future. And under the uncertainty it is understood not a separate social fact of the instability of living space, it is about a fundamental uncertainty of key parameters of social sphere. Philosophers and social scientists (G. Haken, P. Glensdorf, K. George, R. Dafe, J. Coglioty, S. Kurdjumov, X. Maindreih, K. Maintser, L. Rosenfeld, M. Studler and others.) speak about creating the new, synergistic world, opened and difficult but organized, continuously emerging and changing. It emphasizes that the world is unstable, multivariate and alternative, with the pace and direction of development which are not unambiguously specified. Hence, a new understanding of the problem of managing difficultly organized systems: orientation is not so much about the director's desire, but based on the own tendencies of the development of these systems, as well as the assumption of the possibility of existence of zones free of control.

Thus, given the complexity of the social environment, a variety of objectives, content, forms of organization and technology, the changes in the professional culture of teaching staff, any university, first had to take care of flexibility and adaptability of their management systems. Organizational-managerial mechanisms adapt to the identification of new problems and the development of new solutions more than the control which is already taken ${ }^{12}$. The challenge is to develop targeted management of a special type, namely problem-oriented, designed to ensure the effective implementation of large-scale, mass innovations that allow to move from sporadic measures to create a sustainable mechanism for the

\footnotetext{
12 Астахова В.И., Астахова Е.В. Проблемно-ориентированное планирование как определяющий элемент системы управления в вузе. Харьков : Изд-во НУА, 2015. 351 с.
} 
orientation of higher education for a long-term goal and objectives of innovative educational policy. To implement this approach, the basic ideas of all members of the team should be changed. Each of them must be formed a fundamentally new attitude to organizational culture, which requires a long, carefully thought-out work with staff, taking into an account the features of one or another HEI, the specific situation in the country and the world, general trends in society and, first of all, the industry of education.

10. The principle of the organic combination of the democratic foundations of the university with the appropriate elitism of the proposed higher education, which is understood as an exclusively high level of professional responsibility and competence. Elitism, in our interpretation, is not the choice of the different criteria (external tests), the most intelligent students, highly qualified and professionally competent teachers who can grow "pearls of grains", open up opportunities and talents due to the high level and quality of teaching, thanks to the love of those who are taught, and what they teach. Formation of such an attitude of scientific and pedagogical workers in their activity and duty should become the cornerstone of the innovative educational policy of the modern university.

\section{SUMMARY}

So, an important factor in the growth of human capital in Ukraine, the dynamic development of the economy and society as a whole is the reform of education, in particular the university. This requires overcoming a number of problems, among which the most relevant are: a significant increase in the number of HEIs and a rapid increase in the total number of students by 2008, the stabilization and gradual reduction of these indicators since 2010; mismatch of the structure of training specialists to the real needs of the economy; a sharp decline in the quality of higher education; excessive load on one rate (by 2014900 hours a year) and a decrease in the status of scientific and pedagogical workers in the society; insufficient financing and updating of material and technical base; the separation of scientific research from practical implementation; slow pace of integration 
into the European and world scientific and educational space, etc. We highlight the priority directions of the reform of the national higher education and outline the common basic principles of the University's innovative educational policy. Only by overcoming the critical situation, changing the content, forms and methods of organizing the educational process of the HEI, creating fundamentally new scientific, informational, technological, teaching and methodological support, improving the professional pedagogical culture of teachers, where higher education will be able to answer the challenges of time and become an effective sustainable resource for the development of both an individual region and the country as a whole.

\section{REFERENCES}

1. Астахова B.I. Розробка нової освітньої політики як найважливіша умова модернізації сучасної освіти. Вісник Харківського національного університету імені В.Н. Каразіна. 2016. Вип. 37. C. 204-212.

2. Астахова В.И., Астахова Е.В. Проблемно-ориентированное планирование как определяющий элемент системы управления в вузе. Харьков : Изд-во НУА, 2015. 351 с.

3. Вища освіта України. Центр міжнародних проектів НДI прикладних інформаційних технологій «Євро Освіта». URL : http://www.euroosvita. net/prog/print.php/prog/print

4. Державна служба статистики України : Вищі навчальні заклади. URL : http://www.ukrstat.gov.ua/ operativ/operativ2005/osv_rik/ osv_u/vuz_u.html

5. Зарплата українських вчителів - одна 3 найнижчих у світі URL : http://www.unian.ua/society/838832-zarplata-ukrajinskih-vchitelivodna-z-naynijchih-u-sviti.html

6. Макаренко А.Ю. Кадровий аспект проблеми формування ІКТ-компетентності викладачів ЗВО. Наукова скарбниця освіти Донеччини. 2013. № 1 (14). С. 82-88. 
7. Право на освіту та права освітян: теорія і практика в Україні: аналітичний звіт за результатами громадського моніторингу. URL: http://eura.org.ua/wp-content/uploads/2010/01/ERA_Vidrodzhannya_ Право-на-освіту-та-права-освітян_Аналітичний-звіт_-червень2018.pdf

8. Про вищу освіту. Закон України № 1556-VII від 01.07.2014. URL : http://zakon4.rada.gov.ua/laws/show/1556-18

9. Про освіту: Закон України від 05.09.2017 p. № 2145-VIII. URL : http://zakon.rada.gov.ua/laws/show/2145-19

10. Терлоу К. Образование в перспективе. Первое сентября. 2012. 24 ноября. С. 1-2.

\section{Information about the author: Orshansky L. V.}

Doctor of Pedagogical Sciences, Professor, Head of the Department of Technological and Professional Education, Drogobych Ivan Franko State Pedagogical University 4/6, M. Hrushevsky str., Drohobych, Lviv region, 82107, Ukraine 


\section{AXIOLOGICAL ESTABLISHMENT OF A FUTURE SPECIALIST IN THE PROCESS OF PROFESSIONAL EDUCATION}

\section{Pahuta M. V.}

\section{INTRODUCTION}

The question of the improvement of the efficiency of professional education is a key one, as in a general worldwide meaning as well as in the limits of Ukraine in particular. In the conditions of a market economy, the efficiency and competitiveness of any country in the world market is primarily determined by the ability to generate and implement new technologies, to produce a new high-tech product, which is not possible without the involvement of highly skilled workers. Therefore, the problem of the improvement of the quality of professional education is now one of the most urgent and discussed in the educational field of Ukraine.

This problem is extremely multifaceted and complex, since the effectiveness and quality of professional education are affected by many factors, ranging from the banal - logistical support of the educational process to the transformation of worldviews and values, both in the professional education system and in a society as a whole.

It is natural that depending upon the changes of the system of general public values, the change of the attitude of the society to assess of the effectiveness of professional education take place. This is especially true for large-scale socio-economic and socio-political transformations. This is the period that the country is experiencing today. Therefore, along with the revision and transformation of the old and formation of new social values in Ukraine there is a process of revision and change of educational values, including the professional education system ${ }^{1}$.

\footnotetext{
1 Товажнянский Л.Л., Романовський О.Г., Бондаренко В.В., Пономарьов О.С., Черваньова 3.О. Основи педагогіки вищої школи: Навчальний посібник. Харків: НТУ “ХПІ”, 2005. 600 с. (Рос. Мовою). Ст. 392.
} 
M. Kagan points out that values are extremely important component of human consciousness, in a concentrated form of which the content of the culture of the whole society is expressed ${ }^{2}$.

In this context, one of the highest priorities in professional education is axiological function of education, which should realize the values that today are not only important for a society and for the educational system, but also retain its relevance in the future.

For modern systems of professional education of Ukraine, the development of a new value system is typical, which provides individualization, humanization and democratization of the educational process, the use of learning technologies oriented on the activation of cognitive activity and the formation of social and personal important value orientations.

Value orientations are a relatively stable system of orientation of interests and needs of an individual, oriented on certain aspect of social values, which is formed in the process of social development of an individual, his participation in working life $^{3}$. Therefore, professional education can be considered as a means of becoming, development and transformation of value orientations of a future specialist.

In this regard, modern professional education can be and should be considered as a purposeful pedagogical process that ensures the formation and development of a holistic value attitude of an individual to the surrounding reality with the activation of motivational and evaluation processes, in which the acquisition and actualization of professionally relevant knowledge, abilities and skills is due to socially relevant professional and socio-cultural norms, general social, professional and personal value orientations ${ }^{4}$.

Consequently, it is professional education that usually acts as a means of formation, development and transformation of personal value

\footnotetext{
${ }^{2}$ Каган М.С. Человек как проблема современной философии. URL: https://http://www.anthropology.ru/ ru/text/kagan-ms/chelovek-kak-problema-sovremennoy-filosofii

3 Гончаренко С.У. Український педагогічний словник. К.: Либідь, 1997. 376 с. Ст. 357.

4 Елканова Т.М., Чеджемова Н.М., Сергеева Л.В. Аксиологические аспекты гуманитаризации современного профессионального образования. URL: https://www.readera.org/aksiologicheskie-aspektygumanitarizacii-sovremennogo-professionalnogo-140103092
} 
orientation of a future specialist but also a person to make value judgments as to the relevance of his professional or social activities to the actual professional and socio-cultural norms, general public, professional, and personal value orientations.

\section{Value orientations as a means of formation of the professional competence of a future specialist}

In our time, the competence approach is adopted for the characteristic of the compliance level of professional training of a specialist. Thus, $\mathrm{V}$. Kremen and a number of other scholars note that now, in modern society, the most important components in evaluating the quality of education are learning outcomes, which require the development of an integrated system of requirements to the results of education. Not so long ago, the results of training were viewed through the system of formed knowledge, skills and abilities, which is clearly not enough in the current conditions of society's development, and therefore they are now complemented by a set of competences that characterize a broader ability for professional self-realization of personality ${ }^{5}$.

Today, within the competence approach, such notions as competency and competence are used to evaluate the level of professional training of a specialist on the post-Soviet territories. In the post-Soviet psychologicalpedagogical theory and practice it is customary to separate these two terms.

N. Sidorchuk, summarizing the opinions of researchers on the specificity of the terms competency and competence, notes "... their integral character with the respect to "knowledge", "ability" and "skills" (is not contrary to them, but one that includes all their constructive meaning) as the notion of competence is characterized by knowledge, skills, abilities as well as personal qualities (initiative, commitment, goalsetting, responsibility, tolerance, etc.), social adaptation (ability to work in and outside the team), critical thinking as well as the experience in the chosen field. Only in the aggregate these components form behavioral

\footnotetext{
5 Біла книга національної освіти України / Т.Ф. Алексєєнко, В.М. Аніщенко, Г.О. Балл [та ін.]; за заг. ред. акад. В.Г. Кременя. К.: Інформаційні системи, 2010. 342 с. Ст. 244.
} 
models, and accordingly human competency in solving the tasks. On the whole, it can be argued that competency in Western culture is seen as a non-classical phenomenon, rooted in public educational practice and reflecting the existing balance of interests of society (to a lesser extent, of the state), educational institutions, employers, and consumers of services. The notions of competency and competence on the post-Soviet space are interpreted in the classic way as ideal entities that are subjects to explanation and comprehension. In such an interpretation, competency is defined by a complex characteristic of an individual, and competence as its constituent element" ${ }^{\prime 6}$.

I. Kozlovska in the dictionary-guide of a teacher-scientist indicates that competency is a range of powers of a person, issues on which he has some knowledge and experience. Accordingly, a person who has sufficient knowledge, is well-aware and skilled in any field of human activity will be competent ${ }^{7}$.

Analyzing the essence and structure of the notion of competency E. Samoilov includes four elements in competency: 1) personal values; 2) socio-political settings and restrictions; 3) basic training (knowledge, skills, abilities, experience of professional and creative activity); 4) competencies. The competencies are considered as complexes of heterogeneous personal psychological properties (cognitive, affective, volitional), which provide a person with the opportunity to realize complex types of practical-transformative actions and allow to achieve personalsignificant goals regardless of the nature of their origin and social structure in which a person lives and works ${ }^{8}$.

Thus, competency has a value component (personal, social and professional values); cognitive-operational component (basic (professional) knowledge, abilities, skills (KAS) and the methods of productive activity); activity-practical component (competence).

\footnotetext{
6 Сидорчук Н.Г. Порівняльний аналіз понять «компетенція» та «компетентність» як складних психолого-педагогічних феноменів. // Проблеми освіти: збірник наукових праць. Спецвипуск. ВінницяКиїв, 2015. С.78-81. Ст. 80.

${ }_{8}^{7}$ Козловська І.М. Словник-довідник педагога-науковця. Львів: Сполом, 2006. 74 с. Ст. 29.

8 Самойлов Е.А. Ценностные аспекты образования в информационном обществе. URL: https://www.cyberleninka.ru/article/v/tsennostnye-aspekty-obrazovaniya-v-informatsionnom-obschestve
} 
The first component indicates that the activity can be treated as effective when it conforms the human values and promotes harmonious development of the interconnected systems human - socium - nature. The second component of competency determines the importance for the modern world of the fundamental training of a person as the basis for the realization of his personal potential, for the effective accumulation of individual experience of moral-ethical and objectively reasonable transformation of the world. The need for competences as an important component of competency occurs in workers who are in a changing environment, where there are different alternatives of scenario development. In these conditions, competences are seen as a means of self-organization of an individual in the real conditions of their life. The key competencies that are necessary or important for most professions and are important for a society nowadays is the ability to communication and collaboration, leadership and innovation ${ }^{9}$.

In this case, an integral part of a person's overall competence is his or her professional competence. I. Kozlovska defines professional competence as a complete complex of knowledge, abilities, skills, psychological features (qualities), professional positions and acmeological invariants ${ }^{10}$.

In general, today in Ukrainian science, professional competency of a personality is treated not as a set of existing necessary professional knowledge, abilities, skills and professional experience as the ability of their actualization and creative transformation to perform their professional duties in modern dynamic conditions.

Thus, the use of competency approach to professional education in Ukraine includes not only the formation and development of specific, essential to the profession, competencies, but also the formation of living (personal and general societal) and professionally oriented value orientations of a future specialist.

In the process of development of the professional competency of a future specialist, fundamental vital values and personal motives and needs

\footnotetext{
9 Самойлов Е.А. Ценностные аспекты образования в информационном обществе. URL: https://www.cyberleninka.ru/article/v/tsennostnye-aspekty-obrazovaniya-v-informatsionnom-obschestve

${ }^{10}$ Козловська I.M. Словник-довідник педагога-науковця. Львів: Сполом, 2006. 74 с. Ст. 29.
} 
that reflect and influence the attitude of a person to the chosen career play an important role.

Therefore, considering the structure of professional competency, a number of scholars distinguish the following components in it: epistemological, praxeological and axiological. The epistemological component of professional competency defines the system of knowledge and skills that underlie in the basis of the solution of professionally oriented tasks using modern and new technologies. The praxeological component of professional competency determines the development of organizational, communication, analytical, informational, technological, search skills. The axiological component of professional competency is manifested in the value attitude of a person to the chosen profession, professional training and further professional activity, personal attitude to oneself in the profession and one's colleagues, attitude to professionally significant events, attitude to corporate culture and ethics, desire for a high level of acknowledgement of professionally important knowledge and skills, cognitive interest, achievement motivation ${ }^{11}$.

Accordingly, only the activity that do not contradict human and social values and promotes the harmonious development of a personality and society is considered effective in the terms of axiological aspects of professional education.

Thus, the basis of the formation of professional competency of a future specialist is value orientations, which on one hand, act as a process, in which a person creates his own personal value system by selection, transformation and subordination of existing general social and professional value system, bringing them to the state of personal-important value orientation, and on the other hand - act as a means of forming in an individual the ability to navigate in the existing socially important system of values, thus becoming the personal value of a future specialist ${ }^{12}$.

\footnotetext{
11 Кирьякова А.В., Бероева Е.А. Ценностные аспекты развития профессиональной компетентности специалиста в сестеме дополнительного профессионального образования. URL: https://www.cyberleninka.ru/ article/v/tsennostnye-aspekty-razvitiya-professionalnoy-kompetentnosti-spetsialista-v-sisteme-dopolnitelnogoprofessionalnogo-obrazovaniya

12 Дуранов М.Е. Управление проффесиональным образованием будушего специлиста в высшей школе (социокультурный аспект). Челябинск: ЧГАКИ, 2006. 337 с.
} 
Personal, social and professional values, as well as socio-political conditions and limitations are system forming factors of a person's professional competency.

The importance of personal values for the structure of a person's professional competency is due to the fact that they are extremely important for a person himself, his activity and determine the content of a person's activities, including professional ones. Individual values are extremely important and integral components of the structure of a human personality and is closely related to his needs.

Thus, the source of human activity is needs - the state of a living organism, human personality, social group or society as a whole, which expresses the need for something, dependence on the objective conditions of life and is the driving force of their activity, manifested in the activity aimed at the withdrawal of this dependency. It is distinguished biological needs that are inherent for living organisms and social needs that are of socio-historical in nature and predetermined by the development of material production ${ }^{13}$.

The needs are inherently of passive-active, subjectively-objective, socially-personal, subjective character. They are determined by passivity, because they are determined by certain conditions of human biosocial existence, namely deficiency in normal life. Each of us needs food, comfortable living conditions, cognition, etc.

And active character of needs is predetermined by the fact that they are active in overcoming such a deficit. That is, to meet their needs, people prepare or buy food, equip their homes, study, work.

Needs are also subjective as each person experiences lack of something depending on one's peculiarities. The meaning of any deficit is estimated by different people in different ways. They use a variety of methods and means of meeting the needs, which proves their subjective nature.

At the same time, the objective aspect of needs is determined by the fact that each of them is seen in lacking of certain objective objects or

\footnotetext{
${ }^{13}$ Гончаренко С.У. Український педагогічний словник. К.: Либідь, 1997. 376 с. Ст. 266.
} 
phenomena, appears in the objective situation of human life and has an objective value, is satisfied with the help of objective means. The content of the needs of an individual is largely determined by the level of cultural and historical development of the society in which he lives. At each stage, there are certain needs for human communities that are unique to the time at which they function. This determines the social nature of the needs. For example, with the rapid development of information processes and information systems, there was a need in computer technology, without which it is difficult to imagine the work of any institution today. At the same time, people solve this problem depending on the content of their own needs: some use a computer as a document printing tool, others as a efficient image processor, and others as a toy. Thus, needs function as a special form of reflection of the conditions of life of an individual ${ }^{14}$.

Human needs are multifaceted and diverse. Thus, along with higher (ideal) forms of behavior, which are caused by the influence of the learned socio-cultural elements learned in the process of learning, there are also natural forms of behavior that are caused by the natural needs of the body. Fluctuations in the normal rhythm of the biological life of the individual cause the uncertainty of human behavior as a complex system ${ }^{15}$.

Today, one of the most well-known and widespread systems of hierarchy of human needs is the hierarchy developed by A. Maslow ${ }^{16}$. The scholar selected seven hierarchical groups of human needs, which can be roughly in the shape of a pyramid: down in the bottom of the pyramid placed the needs that are important to all people without exception and they are related with the physiological inquiries of human needs (physiological needs) - in food, clothing, warm, shelter, etc; higher are based the needs in security; above, above them, are the needs for love, belonging to socium and demand of society; above, are personal needs for respect, success and authority; over them A. Maslow puts the needs for knowledge and investigation of the surrounding world; even higher are the

\footnotetext{
${ }_{15}^{14}$ Потребнісно-мотиваційна підсистема діяльності. URL: https://www.wikipage.com.ua/1 x8a3.html

Самойлов Е.А. Ценностные аспекты образования в информационном обществе. URL: https://www.cyberleninka.ru/article/v/tsennostnye-aspekty-obrazovaniya-v-informatsionnom-obschestve

${ }^{16}$ Маслоу А. Новые рубежи человеческой природы / Пер. с англ. М.: Смысл, 1999. 425 с.
} 
needs for beauty, harmony and aesthetics; and at the top of the pyramid there are the needs for self-actualization, development of one's abilities and personality as a hole, the realization of one's needs and ideas.

All needs A. Maslow placed accordingly to the degree of their importance, having explained such location by that each person can not feel the needs of a higher level, until the needs of lower levels are not satisfied. This is important to understand that it is not necessarily to satisfy the need in full demand, to move the individual to a higher level of sufficient or partial satisfaction of lower needs.

In particular, A. Maslow points out that in his opinion, a person can't live on bread only, that is, the need to satisfy only physiological needs. But if only there is enough bread (the physiological needs of a person are satisfied), from that time higher needs and motives appear. So gradually a person moves to the highest need - the need for self-development ${ }^{17}$. Thus, the needs, on the one hand, form value attitudes and orientations, and on the other - value orientations of a person correct and develop his motivational and need sphere.

The system of value orientations form component constituent of activity orientation of an individual and expresses the inner basis of its relationship to the surrounding reality. E. Podolska states that the value orientation is an important ideological target means that permeates through the human psyche to the needs and ideals can be both social and individual (personal) ${ }^{18}$.

The sociality of values lies in the fact that they are conditioned by the structure of social relations which are formed by the educational system and practice of the professional and public life. Instead, the individuality of values is linked to the individual characteristics of each individual, his or her life experience. Accordingly, axiological orientation are a complex, dynamic integrative system that synthesizes different levels of interaction between social and individual in a person and determines the general social

\footnotetext{
${ }_{17}^{17}$ Маслоу А. Новые рубежи человеческой природы / Пер. с англ. М.: Смысл, 1999. 425 с.

18 Подольская Е.А. Ценностная ориентация личности как предмет социально-философского иследования: автореф. дис. ... канд. филос. наук. М.: гос. ун-т им. М.В. Ломоносова, 1984. 23 с.
} 
orientation of an individual to value and practical activity in the professional environment ${ }^{19}$.

The development of professional competency from the perspective of axiological approach in professional education, significantly increases the efficiency of mastering a profession, ensuring a future specialist the formation and development of value attitude to future professional activity, increased personal position and internal motivation to continuous selfimprovement in the profession ${ }^{20}$.

The axiological component of professional competency is a kind of basis for the competent formation of a person's behavioral activity as an independent capacity for professional activity ${ }^{21}$. Therefore, professional values are an important factor in determining the professional behavior of a specialist and the interaction of all participants in the professional activity.

At the same time it is important to remember that today professional education is considered by a society not only as a process and result of assimilation of systematic professionally important knowledge, abilities and skills, without which the functioning of modern society is impossible, but also as a means of reproduction and development of the basic value socio-cultural components, formation of a socio-cultural personality of a future specialist.

N. Slusarenko and L. Lipschitz point out that a sociocultural personality can be considered as capable of self-affirmation for the purpose of self-realization and self-development, can act freely and successfully in different spheres of life, independently, creatively and unconventionally think, develop boldly his own behavioral strategies, to choose and be responsible for his actions and his own development, to construct positively his own life to the level of guaranteed achievement of success .

\footnotetext{
19 Елканова Т.М., Чеджемова Н.М., Сергеева Л.В. Аксиологические аспекты гуманитаризации современного профессионального образования. URL: https://www.readera.org/aksiologicheskie-aspektygumanitarizacii-sovremennogo-professionalnogo-140103092

${ }_{20}$ Кирьякова A.В., Бероева Е.А. Ценностные аспекты развития профессиональной компетентности специалиста в сестеме дополнительного профессионального образования. URL: https://www.cyberleninka.ru/ article/v/tsennostnye-aspekty-razvitiya-professionalnoy-kompetentnosti-spetsialista-v-sisteme-dopolnitelnogoprofessionalnogo-obrazovaniya

21 Хуторской А.В. Ключевые компетенции и образовательные стандарты : доклад на отделении философии образования и теории педагогики PAO 23 апреля 2002 года. URL: https://www.eidos.ru/ journal/2002/0423.htm
} 
Thus, a sociocultural personality is a person with a developed sociocultural competency $^{22}$.

Socio-cultural competency is formed on the basis and interrelation of relevant (subject, branch (general) and key) competencies of an individual. Thus the subject and branch competences of a future specialist are formed in him during the study of the subjects of fundamental and professionally oriented cycles $^{23}$.

Sociocultural competency is a system-forming factor of the professional culture of a future specialist, transforming it into a selfsufficient and open system capable of self-regulation and development. On the other hand, sociocultural competency is a subsystem of professional culture because it has the characteristics of a systematic component which components interact seamlessly with each other. Thus, we can state that socio-cultural competency is a set of relevant competences, an intricate, complex characteristic that reflects the integration of professionaltheoretical knowledge, value orientations, personal qualities and practical skills of a future specialists ${ }^{24}$.

\section{Motivational and value aspects of the culture of self-organization and professional adaptation of a future specialist}

The professional training of future professionals is a complex, multifaceted process. The quality of training, as well as its result - the level of competency, is influenced by many factors, including motivation and values of a future specialist's personality. As competences and values, as a planned result of professional training, require a complete combination of all professionally important knowledge, abilities, skills, value orientations with a personality of a future specialist. One of the main tasks of the

\footnotetext{
${ }^{22}$ Слюсаренко Н.В., Липшиц Л.В. Компетентностный подход при формировании социокультурной личности будущего судоводителя. URL: https://www.https://cyberleninka.ru/article/v/kompetentnostnyypodhod-pri-formirovanii-sotsiokulturnoy-lichnosti-buduschego-sudovoditelya

${ }^{23}$ Микитенко Н.О. Технологія формування іншомовної комунікаційної компетентності майбутніх фахівців природничого профілю : монографія / за ред., д. пед. наук, проф., член-кор. НАПН України Г.В. Терещука. Тернопіль: ТНПУ, 2011. 411 с.

${ }^{24}$ Слюсаренко Н.В., Липшиц Л.В. Компетентностный подход при формировании социокультурной личности будущего судоводителя. URL: https://www.https://cyberleninka.ru/article/v/kompetentnostnyypodhod-pri-formirovanii-sotsiokulturnoy-lichnosti-buduschego-sudovoditelya
} 
student period of the development of professional competence of a future specialist is the formation of value attitude to the profession. The motivational value component is characterized by the following indicators: attitude to the profession as a value; understanding its importance to the society and one's own development; admiration for the profession and the pursuit of self-improvement in it, which can not be achieved without the ability of a future specialist to self-organization and further professional adaptation.

The notion of self-organization originated within synergetics and soon found its application in various fields of scientific knowledge. Selforganization, according to the synergistic approach, is a basic property of any living system that is its capacity for self-sufficiency, self-regulation and self-development via the use of its internal reserves and opportunities $^{25}$.

In psychological and pedagogical science, the notion "the culture of self-organization", although it does not have a single sustainable definition and from the point of view of professional education, is usually considered as the ability of a future specialist's personality to self-realization, which is manifested in his purposefulness, activity, validity of self-motivation and planning of his activity, independency, the speed of decision making and responsibility for them, the criticality and objectivity of self-evaluation of the results of one's activity, the sense of duty ${ }^{26}$.

The formation of the culture of self-organization of a personality is formed throughout the life of a person, but with different intensity in different periods of his ontogeny. One of the sensitive periods is the student's age, and it is the period of professional education of an individual. Thus, we can state that leading means of the creation of the culture of self-identity is professional education. Since the formation of the culture of self-organization is possible only after a personality reaches a

\footnotetext{
${ }^{25}$ Князькова О.Н. Мотивационно-ценностные аспекты культуры самоорганизации личности студента. URL: https://www.cyberleninka.ru/article/v/motivatsionno-tsennostnye-aspekty-kultury-samoorganizatsiilichnosti-studenta

${ }^{26}$ Фалеева Л.В. Организованость и самоорганизация как качество личности: сравнительный анализ понятий. Современные проблемы науки и образования. 2012. № 4. С. 266-274. Ст. 266.
} 
certain level of understanding of his life, understanding of a student, a future specialist, his role in the success of educational and further professional activity is a key factor in the functioning of all mechanisms of self-organization of the personality of a future specialist.

The culture of self-organization of a student's personality in the system of professional education is a complex value-systemic formation. In its structure, A. Knyazkova, identifies four components: cognitive, motivational and value, reflective and action-willed ${ }^{27}$.

The phenomenon of self-organization of a personality is most closely related to the value-motivational structure of a personality. The components of motivation-value orientation include motifs that represent a system of dominant motifs that can be viewed in the needs, interests, purpose, etc. and determine the behavior of man and the content of his activity as well as the system of value orientations that reflect the personality value of moral, social and cultural values. Ideals, beliefs, values and worldviews can be regarded as spiritual and value orientations of an individual. Thus, self-organization can be considered as a conscious set of motivation and value-based personality abilities of the personality of a future specialist, which are consistent with the individual characteristics of a subject and find their embodiment in the professional-cognitive values and techniques and the results of activity ${ }^{28}$.

The orientations in cognitive values reflect the results of future professional training in the professional education system. Most professionalcognitive values are the motives, means and results of cognitive activity.

Professional and educational values as one of the components of social values depend on the particular cultural, socio-cultural life and the formed motivational sphere of the personality of a future specialist.

A. Verbytskyi and N. Bakshayeva note that motivational sphere of a personality is a complex, dynamic, multi-level systemic unity of

\footnotetext{
27 Князькова О.Н. Мотивационно-ценностные аспекты культуры самоорганизации личности студента. URL: https://www.cyberleninka.ru/article/v/motivatsionno-tsennostnye-aspekty-kultury-samoorganizatsii-lichnostistudenta

28 Копеина Н.С. Самоорганизация в системе свойств индивидуальности. Личность в системе общественных отномений. Ч. 1. М.: АН СССР, 1983. С. 214-215. Ст. 214.
} 
interconnected components that are the set of socially important and fixed in ideal shape values ${ }^{29}$.

In the structure of the motivational sphere of the personality of a future specialist in the professional education system, there are two dominant groups of motives: motives for professional training and motives for professional activity. The motives for professional training determine the personal attitude of a future specialist to his professional education. Motives for professional activity (professional motives) cause personal attitude of a future specialist to further professional activity and are stable, conscious and taken to the realization of the desire to practice professional activity.

The source of these motives can be both internal needs of an individual and external influences. An inner motivated personally to mastering a profession is characterized by the fact that one's own educational purpose and tasks are meaningful and perceived by a future specialist as necessary and personally-meaningful, and all pedagogical actions and influences from external ones become personal-demanded ${ }^{30}$. Therefore, the presence of inner learning motives contributes to the achievement of high results both in educational activity in general and in the mastering of the chosen profession in particular.

Internal motives for professional training are usually manifested during independent educational and cognitive activity. They are focused on mastering new, professionally important competencies, including important professional knowledge, abilities, skills, and are provided by learning and cognitive and professionally-oriented activity, initiativeness and independency of a future specialist, the desire to form one's own professional competency. Their presence allows a future specialist to overcome independently all difficulties easily and quickly that arise in the course of his professional training.

\footnotetext{
${ }^{29}$ Бакшаева Н.А., Вербицкий А.А. Психология мотивации студентов : Учебное пособие». М.: Логос, 2006. 184 с. Ст. 25-34. URL: https://www.klex.ru/i81

${ }^{30}$ Современная психология мотивации / под ред. Д.А. Леонтьева. М.: Смысл, 2002. 343 с. Ст. 305-306. URL: https://www.https://www.klex.ru/85e
} 
On the other hand, the students who possess only external (that is, influenced by external factors) motivation for professional training, although are able to master the teaching material and solve typical tasks for their chosen profession, are almost unable to make professionally important and correct decisions on their own in difficult, atypical situations and determine and justify the overall direction of their actions ${ }^{31}$.

In all elements of the motivational sphere of a future specialist's personality, there are values and value orientations, which unlike the professionally important knowledge that a future specialist, in the course of professional training, receives in the prepared form, values and value orientations should be formed by himself. At the same time, as M. Kagan points out, the faster a future specialist manages to form his value orientations and personal-internal motives in the process of professional education, the faster and easier is the process of mastering and accumulation of professional knowledge, abilities and skills ${ }^{32}$, and hence the formation of professionally important competencies and accelerating the pace of the development of the culture of self-organization of the personality of a future specialist.

Along with the motivational and value component reflection and selfregulation plays a significant role in the formation of the culture of selforganization and further professional self-adaptation of a future specialist.

Reflection as a component of the culture of self-organization of the personality of a future specialist and his further professional adaptation implies an awareness of his acceptance and evaluation (as a personality, as a student - a future specialist, as a carrier of professionally important competences, etc.). This important aspect of social self-cognition is provided through self-examination and sharing other people's opinion. In psychology, reflection is called any reasoning of the person, aimed at the analysis of oneself (introspection) - one's own states, actions and past events. The depth of reflection, introspection depends on the level of

\footnotetext{
31 Современная психология мотивации / под ред. Д.А. Леонтьева. М.: Смысл, 2002. 343 с. Ст. 303. URL: https://www.https://www.klex.ru/85e

${ }^{32}$ Каган М.С. Человеческая деятельность (Опыт системного анализа). М.: Политиздат, 1974. 328 с. Ст. 285. URL: https://www.twirpx.com/file/356786/
} 
human education, the development of moral feelings and the level of selfcontrol $^{33}$.

Reflection is extremely important for the effective training of future professionals in the professional education system, as it indicates the transition from full inclusion of self-consciousness in activity to the formation of a new attitude to the subject not only to the activity but also to himself in this activity. In the process of training of future specialists in the system of professional education, reflection involves not only understanding of a subject of himself and the nature of his activity, but also an idea how he and his activity is perceived by others. The development of the mechanisms of reflection stimulates introspection, the formation of will, personal maturity of a future specialist.

Along with the motivational-value component and reflection, the structure of the self-organization culture of a future specialist includes selfregulation.

The problem of self-regulation of educational activity of a future specialist plays an extremely important role in the system of professional education, the solution of which is directly related to the task of forming of a socially active personality, who achieves consistently high results in his / her future professional activity.

Self-regulation of educational activity is a system of self-organization of personal behavior, aimed at self-learning and self-education, and ensures the effectiveness of functioning of an individual in educational activity.

The system of self-regulation includes an internal arbitrary process of self-diagnosis of external and internal conditions, goal setting and evaluation of the possibilities and ways of achieving the goal, independence and initiative, self-control and self-assessment of the achieved result, self-correction.

\footnotetext{
33 Психологіс: енциклопедія практичної психології. URL: https://www.psychologis.com.ua/ refleksiya.htm
} 
The process of self-regulation of activity should always begin with self-diagnosis, go through the difficult path of internal work, and end with self-affirmation and self-correction.

A. Zobkov distinguishes the following indices of personal orientation, which are directly involved in the self-regulation of the educational activities of a future specialist: discipline, organization, responsibility, industriousness, independence and initiative, empathy, perseverance, confidence, cognitive activity, originality of thinking, reflection, flexible thinking ${ }^{34}$.

The development of axiological potential and the formation of the culture of self-organization of the personality of a future specialist implies qualitative changes in the value attitude to professional activity and oneself. Understanding by a future specialist the results of cognitive, selforganizing and communicative activity is a system-forming component of value self-determination, value orientations, which activates the process of cognition, creative activity, self-realization and determine the philosophical and ethical and professional choices ${ }^{35}$.

The substantive component of professional education is the formation of the personal culture of a future specialist. Therefore, creating the culture of self-organization of the personality of a future specialist directly related to the professional values and cultural identity, which forms the sociocultural environment in which a future specialist will adapt professionally, function and professionally grow to the level of a professional.

B. Bobrytska notes that mastering the new methods of activity, adjustment to new way of life, altered forms of organization of professional work of a specialist-beginner is realized within an extended period - professional adaptation. This is due to the difference between the characteristics of educational and educational-working activities in the institution of professional education from the conditions of professional

34 Зобков А.В. Саморегуляционные особенности студента - субьекта учебной деятельности. URL: https://www.https://cyberleninka.ru/article/v/samoregulyatsionnye-osobennosti-studenta-subektauchebnoy-deyatelnosti

35 Мелекесов Г.А. развитие аксиологического потенциала личности будущего учителя: автореф. дис. ... д-ра пед. наук. Оренбургский гос. ун-т. Оренбург, 2003. 36 c. URL: https://www.dissercat.com/ content/razvitie-aksiologicheskogo-potentsiala-lichnosti-budushchego-uchitelya/read 
work, changed communication situation, the need to work independently under increased stress, the need to assimilate a new social role in the period when the professional development of a personality and consolidate his values, positive motivation to further professional realization is strengthened ${ }^{36}$.

It should be noted that in the process of professional adaptation the reconstruction of the usual forms of behavior of an individual, ways of organizing his life and rest take place. Thus, the value-motivational aspect of adaptation requires from a former student, and now a young specialist, the reconstruction of the usual style of behavior, achieving greater flexibility in communication, acquiring individual and personal characteristics in accordance with the requirements of the team, which is achieved through a lot of effort with self-improvement, higher level of selfregulation $^{37}$.

\section{CONCLUSIONS}

The values of professional education play an extremely important role in the development of the personality of a future specialist. Personal value orientations formed in the course of professional training are a determining factor in the behavior of a future specialist and the relationships of all participants of professional activity. The development of professional competency from the point of view of the implementation of the axiological approach greatly increases the efficiency of mastering of professional activity, providing a future specialist the development of a value attitude to cognition, professional education and activity, activating personal position and intrinsic motivation for constant professional selfimprovement in the process of professional activity. The development of professional competency of a future specialist is expressed in the need of constant self-development, professional self-education and development of professional self-awareness.

\footnotetext{
36 Бобрицька В.І. Ціннісно-мотиваційні аспекти професійної адаптації фахівців 3 вищою освітою. URL: https://www.enpuir.npu.edu.ua/bitstream/123456789/14240/1/6_Bobrytska_Profes_adaptatsiya_2015.PDF

${ }^{37}$ Bobrytska V.I. Value measuring of psychophysical adaptation of a teacher-beginner // The Strategies of Modern Science Development: International scientific-practical conference. Science Book Publishing House, Yelm, WA, USA, 29-30 March 2013. P. 153-158. Ст. 155.
} 
Values aspects of professional competency in the system of professional education can be traced in such personal characteristics of future professionals as the ability to solve professional tasks of various complexity, mobility and tolerance, the formed system of personal and professional values (value orientations), the developed value-motivational component, unique individuality, creative origin, the formed culture of self-organization, reflection and self-organization.

We believe that the awareness of a future specialist of the axiological component of professional education, its importance for his professional development as a specialist may become a stable internal motive for successful educational and educational-professional activity.

\section{SUMMARY}

The results of theoretical research aimed at studying the axiological essence of professional education, its influence on the formation of professional competence of future specialists are reflected in the work. The structure and the role of motivation-value component on the formation of the culture of self-organization of an individual, his reflection and self-regulation are revealed.

\section{REFERENCES}

1. Товажнянский Л.Л., Романовський О.Г., Бондаренко В.В., Пономарьов О.С., Черваньова 3.О. Основи педагогіки вищої школи: Навчальний посібник. Харків: НТУ «ХПІ», 2005. 600 с. (Рос. Мовою).

2. Каган М.С. Человек как проблема современной философии. URL: https://http://www.anthropology.ru/ru/text/kagan-ms/chelovek-kakproblema-sovremennoy-filosofii

3. Гончаренко С.У. Український педагогічний словник. К.: Либідь, 1997. 376 с.

4. Елканова Т.М., Чеджемова Н.М., Сергеева Л.В. Аксиологические аспекты гуманитаризации современного профессионального образования. URL: https://www.readera.org/aksiologicheskie-aspektygumanitarizacii-sovremennogo-professionalnogo-140103092 
5. Біла книга національної освіти України / Т.Ф. Алексєєнко, В.М. Аніщенко, Г.О. Балл [та ін.]; за заг. ред. акад. В.Г. Кременя. К.: Інформаційні системи, 2010. 342 с.

6. Сидорчук Н.Г. Порівняльний аналіз понять «компетенція» та «компетентність» як складних психолого-педагогічних феноменів. // Проблеми освіти: збірник наукових праць. Спецвипуск. Вінниця-Київ, 2015. С. 78-81.

7. Козловська I.М. Словник-довідник педагога-науковця. Львів: Сполом, 2006. 74 с.

8. Самойлов Е.А. Ценностные аспекты образования в информационном обществе. URL: https://www.cyberleninka.ru/article/ v/tsennostnye-aspekty-obrazovaniya-v-informatsionnom-obschestve

9. Кирьякова А.В., Бероева Е.А. Ценностные аспекты развития профессиональной компетентности специалиста в сестеме дополнительного профессионального образования. URL: https://www.cyberleninka.ru/ article/v/tsennostnye-aspekty-razvitiya-professionalnoy-kompetentnostispetsialista-v-sisteme-dopolnitelnogo-professionalnogo-obrazovaniya

10. Дуранов М.Е. Управление проффесиональным образованием будущего специлиста в высшей школе (социокультурный аспект). Челябинск: ЧГАКИ, 2006. 337c.

11. Потребнісно-мотиваційна підсистема діяльності. URL: https://www.wikipage.com.ua/1x8a3.html

12. Маслоу А. Новые рубежи человеческой природы / Пер. с англ. М.: Смысл, 1999. 425 с.

13. Подольская Е.А. Ценностная ориентация личности как предмет социально-философского иследования: автореф. дис. ... канд. филос. наук. М.: гос. ун-т им. М.В. Ломоносова, 1984. 23 с.

14. Хуторской А.В. Ключевые компетенции и образовательные стандарты : доклад на отделении философии образования и теории педагогики PAO 23 апреля 2002года. URL: https://www.eidos.ru/ journal/2002/0423.htm

15. Слюсаренко Н.В., Липшиц Л.В. Компетентностный подход при формировании социокультурной личности будущего судоводи- 
теля. URL: https://www.https://cyberleninka.ru/article/v/kompetentnostnyypodhod-pri-formirovanii-sotsiokulturnoy-lichnosti-buduschego-sudovoditelya

16. Микитенко Н.О. Технологія формування іншомовної комунікаційної компетентності майбутніх фахівців природничого профілю : монографія / за ред., д. пед. наук, проф., член-кор. НАПН України Г.В. Терещука. Тернопіль: ТНПУ, 2011. 411 с.

17. Князькова О.Н. Мотивационно-ценностные аспекты культуры самоорганизации личности студента. URL: https://www.cyberleninka.ru/ article/v/motivatsionno-tsennostnye-aspekty-kultury-samoorganizatsiilichnosti-studenta

18. Фалеева Л.В. Организованость и самоорганизация как качество личности: сравнительный анализ понятий. Современные проблемы науки и образования. 2012. № 4. С. 266-274.

19. Копеина Н.С. Самоорганизация в системе свойств индивидуальности. Личность в системе общественных отношений. Ч.1. М.: АН ССCР, 1983. С. 214-215.

20. Бакшаева Н.А., Вербицкий А.А. Психология мотивации студентов : Учебное пособие». М.: Логос, 2006. 184 с. URL: https://www.klex.ru/i81

21. Современная психология мотивации / под ред. Д.А. Леонтьева. М.: Смысл, 2002. 343 c. URL: https:// www.klex.ru/85e

22. Каган М.С. Человеческая деятельность (Опыт системного анализа). М.: Политиздат, 1974. 328 c. URL: https://www.twirpx.com/ file/356786/

23. Психологіс: енциклопедія практичної психології. URL: https://www.psychologis.com.ua/refleksiya.htm

24. Зобков А.В. Саморегуляционные особенности студента субьекта учебной деятельности. URL: https://www.cyberleninka.ru/ article/v/samoregulyatsionnye-osobennosti-studenta-subekta-uchebnoydeyatelnosti

25. Мелекесов Г.А. развитие аксиологического потенциала личности будущего учителя: автореф. дис. ... д-ра пед. наук. Оренбургский гос. ун-т. Оренбург, 2003. 36 с. URL: 
https://www.dissercat.com/content/razvitie-aksiologicheskogo-potentsialalichnosti-budushchego-uchitelya/read

26. Бобрицька B.I. Ціннісно-мотиваційні аспекти професійної адаптації фахівців з вищою освітою. URL: https://www.enpuir.npu.edu.ua/ bitstream/123456789/14240/1/6_Bobrytska_Profes_adaptatsiya_2015.PDF

27. Bobrytska V.I. Value measuring of psychophysical adaptation of a teacher-beginner // The Strategies of Modern Science Development: International scientific-practical conference. Science Book Publishing House, Yelm, WA, USA, 29-30 March 2013. P. 153-158.

\section{Information about the author:}

Pahuta M. V.

Candidate of Pedagogic Sciences, Associate Professor,

Doctoral Student at the General Pedagogy and Preschool Education Department,

Drohobych Ivan Franko State Pedagogical University 24, Ivan Franko str., Drohobych, 82100, Ukraine 


\section{LEADING METHODOLOGICAL APPROACHES AND METHODS OF SCIENTIFIC KNOWLEDGE IN THE SPHERE OF COMPARATIVE MUSIC PEDAGOGY}

\section{Stashevska I. O.}

\section{INTRODUCTION}

Intensive integration processes in the international education environment are causing growing interest of researchers to the study of achievements and shortcomings of educational systems of different countries with the purpose of their mutual enrichment and at the same time preserving the national cultural and educational identity.

Thereby, it has become an urgent need to improve and increase knowledge of the means of study, objective reflection and comparison of music-education phenomena and processes that occurred or are current in different cultures, countries, regions, taking into account the new conditions of the global society development and new requirements for the science of teaching.

The analysis of Ukrainian-speaking and Russian-speaking literature of the second half of XX - beginning of XXI century suggests that only a few papers are devoted to foreign music education experience in comparative perspective. Publications of the Soviet period in this area mostly contained an overview and general information. Their authors left aside comparative studies (for example, works by L. Barenboim, O. Bodina, I. Hadalova, Ye. Hurevych, I. Kriazheva, O. Novosad, H. Pozhydaiev, S. Stoianov, L. Schubert; collections of works edited by L. Barenboim, O. Apraksina, etc.).

Some research papers were distinguished by a strong ideological flavour, which was inherent in many publications on comparative education in Soviet times ${ }^{1}$.

\footnotetext{
${ }^{1}$ е.g. Корыхалова Н. П. Кризисные тенденции в буржуазном массовом музыкальном воспитании М.: Музыка. 1989. 112 с.
} 
In this decade, Ukrainian scientists have been striving to objective analysis of various aspects of foreign music education.

A significant contribution to formation of knowledge of the history of European music education has been made by the works of Ukrainian researchers S. Ulanova "Essays on the History of European Music Education and Upbringing: From Antiquity to the XIX Century" (2002), and O. Rostovskiy "Lectures on the History of West-European Music Pedagogy" $(2003)^{2}$.

Along with the significant intensification of research in the postSoviet scientific space of the last decades in the field of comparative education in recent years (I. Kolontaievska, I. Luhovska, O. Oleinikova, L. Riabov, I. Adamek, L. Vakhovskyi, T. Desiatov, V. Zhukovskyi, L. Ziaziun, T. Koshmanova, N. Lavrychenko, A. Maksymenko, O. Matvienko, H. Nikolai, L. Pukhovska, V. Chervonetskyi, O. Lokshyna, etc.), a small number of theses is devoted to the comparative analysis of music education experience of other countries (e.g. theses by A. Vilchkovska, H. Nikolai, R. Polukhin, A. Serhienko, I. Stashevska, A. Utkin and others $)^{3}$.

Taking into account the results of the analysis of the scientific literature in the post-Soviet space, it should be noted that musicpedagogical researches performed on materials of several countries remain relevant. This, in turn, necessitates the specification of the methodological apparatus of comparative music pedagogy, in particular the characteristics

\footnotetext{
2 Ростовський О.Я. Лекції 3 історії західноєвропейської музичної педагогіки. Ніжин: НДПУ ім. М. Гоголя. 2003. 193 с.; Уланова С. І. Нариси історії європейської музичної освіти і виховання: Від античності до початку ХІХ ст. К.: Знання України. 2002. 326 с.

3 Вільчковська А. Е. Розвиток теорії і практики музичного виховання учнів основних шкіл Польщі (1980-2000 рр.) : дис. ... канд. пед. наук : 13.00.01 / Вільчковська Анастасія Едуардівна. К. 2004.207 с.; Ніколаї Г. Ю. Розвиток музично-педагогічної освіти в Польщі (ХХ століття) : дис. ... доктора пед. наук : 13.00.01 / Ніколаї Галина Юріївна. К. 2008. 471 с.; Полухин Р. А. Сравнительный педагогический анализ тенденций развития общего музыкального образования в Республике Беларусь и Республике Польша : Вторая половина XX - начало XXI века : дис. ... канд. пед. наук : 13.00 .02 / Полухин Руслан Анатольевич. Брест. 2005. 250 с.; Сергиенко А. П. История становления и развития музыкального воспитания в Польше: (X - XX вв.) : дис. ... канд. пед. наук : 13.00.01/ Сергиенко Алла Петровна. К., 1993. 194 с.; Сташевська I. О. Розвиток музичної педагогіки в Німеччині (XX століття) : дис. ... доктора пед. наук : 13.00.01/ Сташевська Інна Олегівна. Луганськ. 2011. 550 с.; Уткин А. С. Теория и практика реализации музыкально-педагогической концепции 3. Кодая в современной школе : дисс. ... канд. пед. наук : 13.00.02 / Уткин Анна Сергевна. М. 2019. 291 с.
} 
of methodological approaches, the identification and classification of methods for comparative music-pedagogical research.

\section{Scientific approaches of music-pedagogical comparative studies}

Characterizing the scientific apparatus of comparative music pedagogy, first, it should be noted that the history and present state of the theory and practice of music education in different cultures, countries, regions in a comparative context are regarded as the subject of comparative music education.

Unfortunately, comparative music education research conducted on materials of several countries, is still absent in Ukraine. Underdeveloped are also the problems related to the methodology of comparative research in the field of music education. In this regard, the purpose of this article is to identify the subject, tasks, principles; to characterize methodological approaches; to reveal and classification of methods of comparative music education.

Accordingly, the main tasks of comparative music education research are: to study the process of historical development and current status of common and distinctive features of music education in certain cultures, countries, regions; to shape knowledge of trends and patterns of music education theory and practice in different parts of the world and globally; to identify prognostic opportunities and to develop strategies for improving the national system of music education taking into account negative and progressive international experience in this field. This ensures the implementation of descriptive, explanatory and prognostic functions of comparative music education.

Significant transformations in the methodology of comparative pedagogy of the last decades, characterized by the substitution of ideas of the world as a multiplicity of historically formed regional societies or nations that exist autonomously, to the understanding of transnational interdependence ( $\mathrm{H}$. Kornetov), by the emergence of the so-called world-wide approach (Ye. Brazhnyk) require from comparative researchers to consider their position not only in the national but also in 
the global - international context when analyzing foreign music and educational systems.

Providing theoretical and prognostic significance of comparative music education research requires the implementation of appropriate methodological grounds based on the existing norms, principles and techniques of scientific knowledge. Analysis of papers on the methodology of scientific knowledge, and in particular methodology of educational and comparative educational research (B. Vulfson, Ye. Brazhnyk, M. Vakhovskyi, O. Lokshyna, Z. Malkov, V. Kapranova, V. Kraievskyi, H. Nikolai, A. Novikov, A. Sbruieva and others) and comparative theses in the field of education, particularly music education, of the last decades in Ukraine and other countries of the post-Soviet scientific space allowed to reveal possible methodological principles, approaches and methods, as well as the specifics of information sources of the comparative music education research.

Thus, the methodological framework of comparative studies in the field of music education may be constituted by methodological principles of historicism, determinism, the interrelation of the objective and subjective, the integrity of the philosophical, general and specific scientific levels of methodological analysis, the unity of theory and practice, etc. Also the systems, synergetic, historical, cultural, civilization, anthropological, axiological, paradigmatic, comparative, parametric, intonational, communicative informational approaches and the approach of the general social context are worth mentioning.

We shall consider these methodological approaches in a greater detail in the context of the tasks of comparative music education.

Thus, systemic and synergistic approaches (I. Blauberh, E. Yudin, H. Khaken, I. Pryhozhyn) create opportunities for considering the subject of comparative music-pedagogical research as a complex structured open dynamic system. For example, the analysis of the peculiarities of the functioning of music education systems of certain countries, local musiceducational environments of certain regions or educational institutions, characteristic features of certain music-pedagogical concepts, etc. is carried 
out taking into account, first, their openness to permanent changes caused with socio-cultural factors, ability to self-organization and self-regulation, second, their hierarchical relations with other objects and phenomena, and, third, the specifics of the interaction of their own structural elements at different levels: conceptual, meaningful, operational, effective, etc.

The history and culture approach (M. Bakhtin, V. Bibler) provides the collection and description of historical facts, identifying musical and cultural traditions, evolutionary prerequisites, phases, trends and patterns of music education processes and phenomena in the context of general cultural life of the country studied in different historical periods that are significant for the research. It allows to take into account various intersections and confluence of music education ideas and practices with other socio-cultural phenomena - philosophy, aesthetics, general pedagogy, art, performing arts, religion, the media and others.

According to N. Borytko, from birth, a person is confronted with the experience of previous generations, which in a concentrated form is expressed in culture, sociocultural values, the interiorization of which in the pedagogical aspect "is ensured within the framework of a cultural approach through the organization of a pedagogically appropriate environment (public opinion, traditions, collective affairs, events, holidays, etc. $)^{\text {"4 }}$.

Thus, on the basis of the historical and cultural approach, the process of music education itself is positioned as a socio-cultural phenomenon, functioning according to the existing type of culture and aimed at transferring and developing music and cultural traditions by attracting a new generation to the values of music art, enriching the music and cultural experience and thereby forming the music culture of each member of society as an integral part of the spiritual culture of the whole society.

The civilization approach (H. Kornetov) involves the study of the history and current state of music education of certain countries on the basis of mutual influence of different cultural traditions in the context of music education process in the whole world.

\footnotetext{
${ }^{4}$ Борытко Н. М. Педагог в пространствах современного воспитания. Волгоград: Перемена, 2001. С. 9-10.
} 
The anthropological approach provides the investigation of music education processes and phenomena from the standpoint of a man and his needs.

The axiological approach (I. Ziaziun, M. Kahan, O. Sukhomlynska) enables to reveal in the scientific sphere the educational ideas about the value of musical training, education and development in the social and personal perspectives, and to disclose the role of music education in the context of preservation and transmission of music, cultural and human values, humane society development, etc.

The paradigmatic approach helps to identify music education paradigms that prevail in the investigated areas in certain historical periods with the help of the analysis of music education concepts and musical and educational reality, and to analyze them from the standpoint of the past. O. Nikolaieva discriminates the paradigmatic educational approach to the study of the history of music education, and emphasizes that it can be applied on several levels: the level of the main historical stages in the development of music education; the level of each specialization of music education (national, religious, social); the level of individual musical educational concepts ${ }^{5}$.

The comparative approach allows revealing the specifics of music education development in different parts of the world, ties, commonness and differences of music education models, regulations and characteristic features of their implementation in different historical periods. It also helps to identify positive and negative aspects, and possible ways of improving theory and practice of music education at the national level by comparing domestic and foreign music education experience.

The parametric approach (I. Luhovska), through the use of parametric estimation procedures and parametric comparison, opens opportunities for identifying features of the investigated objects on the basis of a unified system of qualitative and quantitative parameters, and, thus, it allows performing their element-by-element structural and functional comparative analysis.

\footnotetext{
Психология музыкальной деятельности: теория и практика. [под ред. Г. М. Цыпина]. М.: Издательский центр „Академия”. 2003. С. 300.
} 
The approach of general social context (L. Riabov, M. Vakhovskyi) can be used to identify the external socio-historical factors and conditions that determine the formation and evolution of musical and educational ideas, to compare views and conceptions of eminent personalities in music education through the interpretation of their quotations as products of activity in specific social, cultural and historical conditions.

The essence of the intonational approach (O. Nikolaieva) is supposed to trace in the history of music education the succession of fixed intonation guidelines in terms of the evolution of music art as the art of "the intonated meaning" (B. Asafiev) ${ }^{6}$. This approach involves consideration of music education of different cultures, countries, and regions with regard to its types. Their specific character is revealed due to the intonation analysis of any type of musical culture (national, social, religious, composing, performing, listeners', vocal, piano, conducting, culture of musical theory and music education, etc.). It also includes analysis of the correlation of music education systems with different musical styles.

In the context of the study, M. Vakhovskyi's opinion regarding the expediency of distinguishing quantitative and qualitative approaches in comparative pedagogical research deserves attention. The scientist rightly points out that it is more correct to speak "not about quantitative and qualitative analysis as separate methods of comparative pedagogy, but about quantitative and qualitative approaches to the study of educational problems, which are a specially formed set of research methods (quantitative or qualitative) for solving certain tasks"7. M. Vakhovsky also states that "the approach, unlike the method, determines the general scientific position of the researcher, which in turn forms the basis of the strategy of scientific search"

Based on M. Vakhovskyi's position on the essence of quantitative and qualitative approaches in comparative-pedagogical research, it is possible

\footnotetext{
6 Психология музыкальной деятельности: теория и практика. [под ред. Г. М. Цыпина]. М.: Издательский центр „Академия”. 2003. С. 298.

7 Ваховський М. Л. Кількісний і якісний підходи в порівняльно-педагогічному дослідженні. Ocвіта та педагогічна наука. 2016. № 1. С. 65.

${ }^{8}$ Ваховський М. Л. Кількісний і якісний підходи в порівняльно-педагогічному дослідженні. Ocвima та педагогічна наука. 2016. № 1. С. 65.
} 
to distinguish their role in the scientific knowledge of music-pedagogical problems. Thus, a quantitative approach allows establishing causality, identifying common laws, patterns and principles in music education. The qualitative approach helps to identify unique characteristics of musicpedagogical processes and phenomena, to consider them in dynamics and to form the basis for the interpretation of quantitative indicators.

In the context of comparative research in the sphere of training of future music teachers, $\mathrm{H}$. Nikolai emphasizes the methodological value of the communicative and informational approach, the application of which opens the possibilities for the analysis of the investigated process from the point of view of the polylog between its subjects and works of art, which reflect interpersonal relations 9 .

Indeed, the use of a communicative-informational approach in musicpedagogical comparative studies allows us to take into account the important functions of musical art in society - communicative and informational, and, on this basis, to study music-pedagogical processes and phenomena as in the context of subject-subject relations (for example, teacher - student, student - student, etc.), and from the perspective of subject-object interaction (for example, personality - a piece of music).

\section{Methods of comparative study of music-pedagogical processes and phenomena}

It is known that conducting any scientific research requires careful selection of research methods, and the logic of their application is justified, primarily by choosing the subject, objectives and tasks of the research, i.e. the set of research methods must correlate with the specific processes and phenomena investigated.

Comparative music education studies music education processes and phenomena in comparison, so the basic tools of comparative education research are general scientific methods and specific methods of scientific knowledge inherent in education. However, the interdisciplinary nature of

\footnotetext{
${ }^{9}$ Ніколаї Г. Музично-педагогічна компаративістика: шляхи розвитку. Порівняльно-педагогічні студіï. 2010. № 1-2. Режим доступу: http://pps.udpu.edu.ua/issue/view/947
} 
comparative music education also involves the use of methods of other scientific fields - history, philosophy, psychology, sociology, musicology, mathematics, source study, etc.

Various methods that can also be used for the realization of objectives and tasks of a research work on comparative music education were discovered with the help of analysis of scientific and educational literature on comparative education, namely the works of the leading Russian and Ukrainian comparative education experts B.Vulfson, Z. Malkova, O. Dzhurynskyi, Ye. Brazhnyk, V. Kapranova, A. Sbruieva and others, and also theses and comparative education research in Ukraine and Russia of the last decades (N. Abashkina, I. Adamek, L. Vakhovskyi, T. Desiatova, V. Zhukovskyi, L. Ziaziun, A. Ionova, E. Ismailova, I. Kolontaievska, T. Koshmanova, N. Lavrychenko, O. Leszczynskyi, I. Luhovska, A. Maksymenko, O. Matvienko, H. Nikolai, O. Oleinikova, L. Pukhovska, I. Radionova, A. Rastryhina, L. Riabov, S. Sinenko, V. Chervonetskyi, etc.).

The same as for any type of research such general scientific methods as theoretical analysis and synthesis, induction and deduction, abstraction and concretization, problematization, analogy, modeling, synthesis, systematization, and classification are very important for research on comparative music education. They allow identifying the key problem, forming the scientific subject-matter and the concept of the research, singling out essential characteristics, major trends and patterns of music education phenomena, summarizing theoretical and practical experience on the research, etc.

Collecting and processing factual material with various methods is a necessary basis for comparative music education research.

Thus, comparative music education research is impossible without studying government regulations, educational materials, curricula, teacher's documentation, and statistical data of the countries studied. The facts that are important to the knowledge and comparison of music education objects and phenomena are contained in fundamental historical, psychological, educational and musical works, encyclopedias and reference journals, memoirs, monographs, collections of scientific papers 
and conference proceedings, periodicals of past centuries and the present that can be found in domestic and foreign libraries, on the Internet, etc.

Studying the up-to-date foreign authors' publications that are devoted to the problems of history of music education concepts and practice development, organization of music education at traditional and specialized comprehensive school and nonschool educational establishments, music education of adults, professional training in musical culture and education is especially important for the versatile coverage of the subject of the research in the field of comparative music education.

Authentic sources of different historical periods, for example, ancient music theory treatises, music education papers, textbooks and manuals on music education, music dictionaries, articles in periodicals, collections of songs, etc. are valuable for objective analysis of foreign music education thought and practice in past centuries.

Translation of authentic literature is an important complementary method of comparative music education research. During the research the author has to be very careful when translating names and terms that, depending on the language, the historical period, and even the geographical region, may have different specific explication. One should also interpret terms of international music education systems with caution and integrate them into the national scientific and educational language carefully.

It should be noted that the degree of reliability of results of comparative music education research largely depends not only on the number of the sources studied, but on the completeness and accuracy of the information contained in them. It is almost impossible to process all the literature that is relevant to the research problem; that is why when working with sources, it is advisable to use the method of general array in combination with the selective method, when most of the sources selected according to certain criteria are analyzed. The selection of material for comparative music education research can be carried out by chronological, geographical, thematic or other characteristics.

Great assistance in studying various aspects of music education reality in the country or region investigated is provided by such empirical 
methods as observation, interviews (oral - interview, written - questioning, testing), and the peer review method. They help to reveal views on the subject of the research held by different groups of respondents: teachers, students and their parents, and heads of educational institutions. As a result, the researcher receives important factual material that on being compared with the information contained in regulatory documents and literature provides a relatively complete and objective view of the subject of the research.

Description of factual information is an essential method of research in the field of comparative music education. The issue of the interrelation of the factual material description and its analytical interpretation is relevant today. B. Vulfson rightly emphasized that excessive enthusiasm about facts comes at the expense of theoretical understanding, and, on the other hand, "such a reflection will be fruitful only if it is based on a thorough study of the specific facts and events"10. According to B. Vulfson, it is in the literature devoted to foreign problems that the ratio of factual material can often be higher than in works on the national education system; and the systematic description of new and little-known facts can serve as one of the important independent research tasks and an essential element of the comparative education research ${ }^{11}$.

Methods of Mathematical Statistics (registration, ranking, scaling, comparison) and also such sociological methods as sociometry, which allows to present the research results processed with mathematical methods in the form of tables, charts, graphs, and the content analysis, which is used for accurate and objective quantitative and qualitative content analysis of unsystematized information sources (regulations, nonfiction, interviews, questionnaires, etc.), are additional means of processing the received factual material.

The comparative analysis is a specific method used in the field of comparative education. As a complex method that includes a set of

\footnotetext{
10 Вульфсон Б. Л. Сравнительная педагогика. История и современные проблемы. М.: УРАО. 2003. C. 82.

11 Вульфсон Б. Л. Сравнительная педагогика. История и современные проблемы. М.: УРАО. 2003. C. 82.
} 
research techniques aimed at identifying the common and the different in education objects compared must be central when conducting the comparative music education research.

The method of binary comparison or binary analysis, which allows for "deep and detailed comparison of educational systems of two countries in which educational issues fit into a broad historical-cultural and socio-political context", is a technique of comparative analysis ${ }^{12}$. B. Vulfson distinguishes two types of binary comparison. The first involves the comparison of the national education system (as the basic one) and the foreign; and the second the comparison of two educational systems of foreign countries ${ }^{13}$.

According to the results of the analysis of the dissertation works of the post-Soviet countries, the studies in the field of foreign music pedagogy in them are still aimed at studying the music and pedagogical experience of individual countries and identifying the possibilities of improving the studied branch at the national level, taking into account the results of the scientific work carried out.

The relative homogeneity of the objects that are compared is essential for conducting the comparative analysis. Therefore, for comparison it is better to select the countries with relatively close historical and cultural traditions in the socio-economic, political, religious and other aspects. E. Ismailov singles out the principle of adequacy, "according to which the educational phenomena and processes bearing adequate general didactic regularities may be incorporated into the practice of the systems compared", as a necessary principle of contrastive analysis as a technique of comparative education analysis in this context ${ }^{14}$. Thus, as it was noted by A. Sbruieva, "when choosing the objects to compare many factors must be considered: the historical, cultural, economic, philosophical, religious, demographic, sociological, and teaching" ${ }^{\prime 15}$.

\footnotetext{
12 Вульфсон Б. Л. Сравнительная педагогика. История и современные проблемы. М.: УРАО. 2003. C. 55.

Вульфсон Б. Л. Сравнительная педагогика. История и современные проблемы. М.: УРАО. 2003. С. 55.

14 Исмаилов Э. Э. Сравнительно-педагогический анализ систем среднего профессионального образования Швеции и России : дис. ... д-ра пед. наук : 13.00 .08 / Исмаилов Эльхан Эюб оглы. Калининград. 2004. С. 17.

${ }^{15}$ Сбруєва А. А. Порівняльна педагогіка. Суми: СДПУ ім. А.С.Макаренка. 1999. С. 22.
} 
The comparison can be either synchronous, i.e. have a unified chronological framework, and asynchronous, when researchers compare the processes or phenomena that occurred in different historical periods.

The method of modeling is an effective technique that helps researchers to carry out the comparative analysis. For example, L. Riabov uses modeling for developing a working hypothetical model of a system of higher education of the developed countries as a reference for comparison $^{16}$.

An important condition for efficiency of the comparative analysis of music education processes and phenomena is a selection of certain parameters for their comparison.

The scientific study of the concept of the parametric approach to comparing of schooling in different countries was carried out in the thesis of I. Luhovska. The researcher proposed to use methods of parametric estimation and parametric comparison. According to the author, the technological procedure of parametric assessment is the identification of the real state of school education systems in different countries on the basis of a unified system of qualitative and quantitative parameters, and technological procedure of parametric comparison - element-by-element structural and functional comparative analysis of school education systems in different countries, based on the results of parametric evaluation ${ }^{17}$.

Thus, it is advisable to select the most essential elements for the comparison procedure (e.g., social and educational conditions, objectives, tasks, contents, methods and forms of music education activities, the specific character of music education systems management, etc.).

Comparative education research is carried out within the selected chronological framework and can cover different historical periods. In this context, scientific historical methods are an important means of conducting the comparative music education research: the analysis of sources and the

\footnotetext{
${ }^{16}$ Рябов Л. П. Сравнительно-педагогический анализ систем высшего профессионального образования развитых стран : автореф. дис. на соискание науч. степени д-ра пед. наук : спец. 13.00.01 «Общая педагогіка»/ Л. П. Рябов. М. 1998. 49 с.

17 Луговская И. Р. Параметрический подход к анализу систем школьного образования разных стран : дис. ... д-ра пед. наук : 13.00.01 / Луговская Ирина Робертовна. Санкт-Петербург. 2004. 393 с.
} 
historiographical analysis; the chronological and descriptive-analytical methods that involve consideration of the historiography of the subject of investigation, the search and processing of important encyclopedias, philosophical, psychological, educational, cultural, musicological, and regulatory sources, archival documents, collection, systematization and description of historical facts; the method of periodization, the comparative historical, retrospective and causal analysis that can detect the features of the evolution of music education ideas and the real state of music education practice in certain historical periods, define the main stages, political, economic, socio-cultural factors and prerequisites for shaping and development of music education phenomena; the paradigmatic method that is needed to identify the leading music education paradigms that prevailed in different historical periods and the main determinants of their change.

The forecasting is one of the key methods of comparative music education aimed at identifying ways of improvement and prospects of further development for the national theory and practice of music education, taking into account the results of the comparative research conducted.

Concluding the consideration of the methods of scientific knowledge that can be used in the comparative music education research, it should be noted that there is not a strictly regulated set of methods that are specific only for comparative education, and in particular music education research. Researchers have been implementing both general scientific and special methods that are characteristic of certain scientific fields and can be adapted for solving specific research problems.

However, in order to consolidate and systematize the material given above, we will try to classify the methods of comparative education research that can be an effective means of scientific knowledge particularly in the field of comparative music education.

The analysis of publications that reveal the foundations of methodology of scientific knowledge ${ }^{18}$ indicates the absence of a unified classification of the education research methods.

\footnotetext{
18 Брызгалова С. И. Введение в научно-педагогическое исследование. Калининград: Изд-во КГУ. 2003. С. 54; Загвязинский В. И. Методология и методика дидактического исследования. М.: Педагогика.
} 
Concerning methods of comparative education research, the wellknown Russian comparative scientist B.Vulfson singles out two groups of methods - general scientific and special (appropriate for the object investigated and the main sources studied $)^{19}$.

As noted by O. Novikov, to discover a class of objects means to identify those essential characteristics that are common to all the objects that make up this class ${ }^{20}$.

Thus, the classification of scientific methods must be based on their distribution according to certain criteria. The process of identifying these features can be performed by different criteria, for example:

- by the level of scientific knowledge: empirical and theoretical;

- by the stages of the research: diagnostic, information gathering, organizational, interpretative, generalizing, etc.;

- by way of displaying knowledge: descriptive and explanatory;

- by the level of methodological analysis: philosophical, generalscientific, concrete-scientific, subject-applied (disciplinary), interdisciplinary;

- by the specifics of the substantive essence of the studied objects: sociological, mathematical, humanitarian, etc.

- by way of application: simple and complex.

However, none of these options can cover the whole range of comparative pedagogy methods. Thus, in order to systematize the basic methods that can be applied for accomplishing objectives and solving tasks of the comparative education research, and particularly music education research, we propose the following complex structured classification based on several criteria: research stages, levels of scientific knowledge and methodological analysis (Table 1).

1982. С. 104.; Краевский В. В. Общие основы педагогики. М.- Волгоград: Перемена. 2002. С. 144-156; Кыверляг А. А. Методы исследований в профессиональной педагогике. Таллин: Валгус. 1980. 334 с.; Новиков А. М. Докторская диссертация? М.: Эгвес. 2003. С. 57-58; Рудницька О. П., Болгарський А. Г., Свистєльнікова Т. Ю. Основи педагогічних досліджень. К.: НПУ імені М. П. Драгоманова. 1998. С. 52. та ін. C. 80 .

Вульфсон Б. Л. Сравнительная педагогика. История и современные проблемы. М.: УРАО. 2003.

${ }^{20}$ Новиков А. М. Докторская диссертация? М.: Эгвес. 2003. С. 37. 


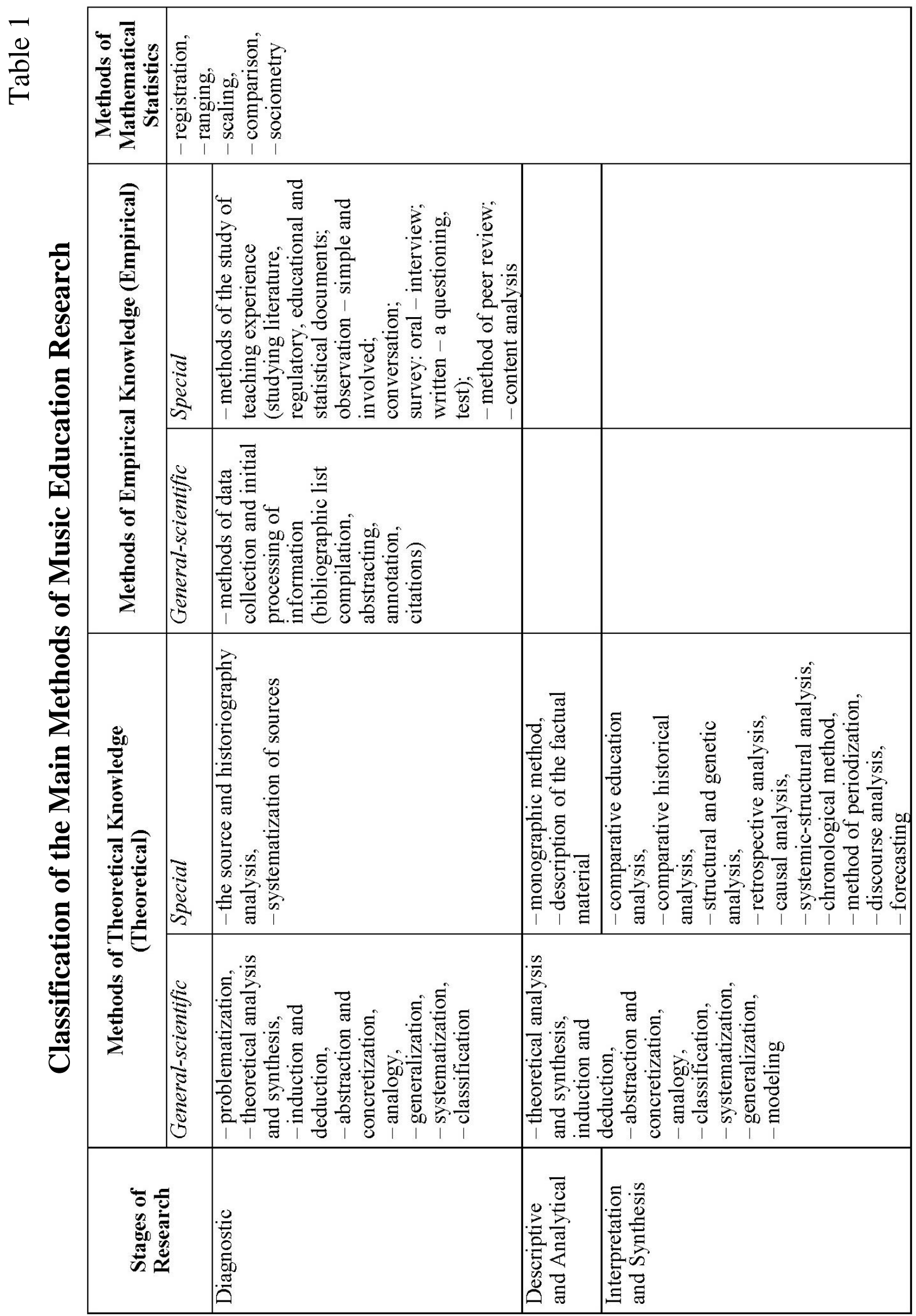


It should be pointed out that the selection of classification groups is arbitrary, because, as it is known, all the methods chosen for a particular research should inter-relate and complement each other.

The classification of methods of the comparative education research in Table 1 does not suggest that it is comprehensive and complete. The main purpose of the author is drawing attention of comparative education researchers to the existing problem, as well as the pertinence of further expansion and streamlining of comparative music education methods, because the breadth of their spectrum and the degree of consistency between them are essential factors that affect the results of the research and allow to obtain the most complete and objective information about the subject of the research.

\section{CONCLUSIONS}

Thus, the crucial role of music education in the transmission of musical and cultural traditions and formation of music culture of the younger generation, as well as in the significant impact on the humanization of society, requires the study and implementation of the best achievements of world music education in the national system of music education. However, the analysis has shown that a coherent concept of the mechanism of comparative studies of music education systems of different countries does not yet exist in science of the post-Soviet countries. The characterization of individual components of the comparative music education methodology carried out in this article, of course, does not exhaust all aspects of the methodology of comparative music education research, and requires further detailed development.

It is advisable in this context to create a methodology for comparative analysis of music and educational systems of different countries with the purpose of their enrichment, the development of new methodological approaches specific for comparative music pedagogy, a thorough study of the possibilities of using scientific methods of certain scientific disciplines (history, philosophy, psychology, sociology, mathematics, source studies, etc.) in the process of comparative music and pedagogical research, a 
detailed description of the selection and processing characteristics in the source base, determining the most significant parameters for the assessment and comparative analysis of music and pedagogical processes and phenomena.

\section{SUMMARY}

The necessity of specifying the methodological apparatus of comparative music pedagogy, in particular the characteristics of methodological approaches, definition and classification of methods of comparative music pedagogical research, was actualized in the article. It was found that the subject of comparative music pedagogy is the history and current state of music education theory and practice in different cultures, countries and regions in a comparative perspective. It is emphasized importance to consider the positions of foreign music and educational systems in the process of the analysis not only in the national but also in the global - international context. The key tasks and principles of comparative research in the sphere of music pedagogy were specified. The scientific approaches of comparative music pedagogy are characterized: systematic, synergetic, historical and cultural, civilizational, anthropological, axiological, paradigmatic, comparative, parametric, approach of the general social context, intonational, communicative-informational, etc. Various methods have been identified that can be used to accomplish the goals and objectives of research in the sphere of music-pedagogical comparative studies. In order to systematize the basic methods of comparative music-pedagogical research, their complex-structured classification was carried out, which is based on the selection of certain criteria: stages of research, levels of scientific knowledge and levels of methodological analysis. Perspective directions of further development in methodological foundations of comparative music pedagogy have been determined. 


\section{REFERENCES}

1. Борытко Н. M. Педагог в пространствах современного воспитания : монография. Волгоград: Перемена. 2001. 214 с.

2. Брызгалова С. И. Введение в научно-педагогическое исследование : Учебное пособие. [3-е изд., испр. и доп.]. Калининград: Изд-во КГУ. 2003. 151 с.

3. Ваховський М. Л. Кількісний і якісний підходи в порівняльнопедагогічному дослідженні. Освіта та педагогічна наука. 2016. № 1. C. 64-68.

4. Ваховський М. Методологічні аспекти порівняльного аналізу педагогічних ідей Г. Манна та К. Ушинського. Педагогіка, психологія та медико-біологічні проблеми фізичного виховання $i$ спорту. 2008. № 10. C. 26-30.

5. Вільчковська А. Е. Розвиток теорії i практики музичного виховання учнів основних шкіл Польщі (1980-2000 рр.) : дис. ... канд. пед. наук : 13.00.01 / Вільчковська Анастасія Едуардівна. К. 2004. $207 \mathrm{c}$.

6. Вульфсон Б. Л. Сравнительная педагогика. История и современные проблемы. М.: УРАО. 2003. 232 с.

7. Загвязинский В. И. Методология и методика дидактического исследования. М.: Педагогика. 1982. 159 с.

8. Исмаилов Э. Э. Сравнительно-педагогический анализ систем среднего профессионального образования Швеции и России : дис. ... д-ра пед. наук : 13.00.08 / Исмаилов Эльхан Эюб оглы. Калининград, 2004. 241 c.

9. Комарова А. А. Сравнительный анализ систем обучения иностранным языкам в военных вузах России и США : автореф. дис. на соискание науч. степени канд. пед. наук : спец. 13.00.01 / А. А. Комарова. Нижний Новгород. 2003. 28 с.

10. Корыхалова Н. П. Кризисные тенденции в буржуазном массовом музыкальном воспитании. М.: Музыка. 1989. 112 с.

11. Краевский В. В. Общие основы педагогики. М.- Волгоград: Перемена. 2002. 163 с. 
12. Кыверляг А. А. Методы исследований в профессиональной педагогике. Таллин: Валгус. 1980. 334 с.

13. Луговская И. Р. Параметрический подход к анализу систем школьного образования разных стран : дис. ... д-ра пед. наук : 13.00.01 / Луговская Ирина Робертовна. Санкт-Петербург. 2004. 393 с.

14. Ніколаї Г. Музично-педагогічна компаративістика: шляхи розвитку. Порівняльно-педагогічні студї. 2010. № 1-2. Режим доступу: http://pps.udpu.edu.ua/issue/view/947

15. Ніколаї Г. Ю. Розвиток музично-педагогічної освіти в Польщі (XX століття) : дис. ... доктора пед. наук : 13.00.01 / Ніколаї Галина Юріївна. К. 2008. 471 с.

16. Новиков А. М. Докторская диссертация? М.: Эгвес. 2003. $120 \mathrm{c}$.

17. Полухин P. А. Сравнительный педагогический анализ тенденций развития общего музыкального образования в Республике Беларусь и Республике Польша : Вторая половина XX - начало XXI века : дис. ... канд. пед. наук : 13.00.02 / Полухин Руслан Анатольевич. Брест. 2005. 250 с.

18. Психология музыкальной деятельности: теория и практика : [учеб. пособ. для студентов муз. фак. высш. пед. учеб. заведений] / [под ред. Г. М. Цыпина]. М.: Издательский центр «Академия». 2003. $368 \mathrm{c}$.

19. Ростовський О.Я. Лекції 3 історії західноєвропейської музичної педагогіки : [навч. посіб.]. Ніжин: НДПУ ім. М. Гоголя. 2003. 193 c.

20. Рудницька О. П., Болгарський А. Г., Свистєльнікова Т. Ю. Основи педагогічних досліджень. К.: НПУ імені М. П. Драгоманова. 1998. $143 \mathrm{c}$.

21. Рябов Л. П. Сравнительно-педагогический анализ систем высшего профессионального образования развитых стран : автореф. дис. на соискание науч. степени д-ра пед. наук : спец. 13.00.01 «Общая педагогіка» / Л. П. Рябов. М., 1998. 49 с. 
22. Сбруєва А. А. Порівняльна педагогіка : [навч. посіб.]. Суми: СДПУ ім. А. С. Макаренка. 1999. 301 с.

23. Сергиенко А. П. История становления и развития музыкального воспитания в Польше: (X - XX вв.) : дис. ... канд. пед. наук : 13.00.01/ Сергиенко Алла Петровна. К. 1993. 194 с.

24. Сташевська І. О. Розвиток музичної педагогіки в Німеччині (XX століття) : дис. ... доктора пед. наук : 13.00 .01 / Сташевська Інна Олегівна. Луганськ. 2011. 550 с.

25. Уланова С. І. Нариси історії європейської музичної освіти $\mathrm{i}$ виховання: Від античності до початку XIX ст. К.: Знання України. 2002. $326 \mathrm{c}$.

26. Уткин А.С. Теория и практика реализации музыкальнопедагогической концепции 3. Кодая в современной школе : дисс. ... канд. пед. наук : 13.00.02 / Уткин Анна Сергевна. М. 2019. 291 с.

\section{Information about the author:} Stashevska I. O.

Doctor of Pedagogical Sciences, Professor, Honored Art Worker of Ukraine, Vice-rector for Educational Work, Kharkiv State Academy of Culture 4, Bursatskyi uzviz, Kharkiv, Ukraine 


\section{THE STIMULATION OF PROFESSIONAL SELF-IMPROVEMENT OF PRIMARY SCHOOL TEACHERS IN THE POSTGRADUATE EDUCATION SYSTEM: TARGET-SETTING}

\section{Sushchenko L. O.}

\section{INTRODUCTION}

The desire of the teacher for professional self-improvement is a sociopedagogical phenomenon, which is connected with the teacher's personal and value orientations for the best fulfilment of his/her pedagogical functions. Therefore, the theoretical basis for constructing the concept of stimulating the professional self-improvement of teachers in the system of postgraduate education is the modern educational paradigms: humanistic, cultural, the concept of continuing vocational education and acmeological, personally-active, competence, systematic approaches.

In this regard, the active self-expression of one's own professionalism of elementary school teachers covers acts of extraction, above all, his or her targeted professional orientation as the most important socially important internal mover of professional selfimprovement, personal, information traits, which involves their comparison and analysis, abstraction and focus on the main, characterization of the substantive essence of a professional position as a bringer of subjective pedagogical experience, its adequacy, etc. A competent, conscious self-examination of the purpose and effectiveness of one's professional activity is the first mandatory phase of professional self-improvement. But this process should be approached comprehensively. Directing self-development and enriching a teacher's creative potential in one or more directions and neglecting others lead to one-sidedness and do not produce the desired result. As an example, that is excessive praise the innovation, idealization, and sometimes 
falsification of its results, could mostly lead to stereotypes, result in true projection, harms the development of true teacher professionalism ${ }^{1}$.

In the process of pedagogical diagnosis, which is being actively pursued in all structures of postgraduate education, much attention is paid to the identification of problems of a didactic nature, rather than to the study of the professional positions of teachers, which mostly reflects the level of their analytical culture in an objective assessment of their professional level.

In our experiment, there were no cases (327 people were interviewed) that the teacher answered that his/her professionalism was always assessed objectively. The main reason for this situation is that it is not professionalism, not even the professional level of the teacher, not his/her attitude to the educational environment that is being examined and diagnosed, but only some aspects of this complex formation. Own socio-professional positions of teachers are out of focus, as well as revealed an understanding of new pedagogical phenomena from a position of professionalism, resulting in the concealment of unresolved problematic issues, understanding them through the prism of the author's individuality.

In this regard, it should be remembered that teachers belong to the socio-professional group of intelligentsia whose value is the continued opportunity to positively influence on the development of children and those who are around them (parents, neighbours, teachers, etc.). In our view, such an influence is one fundamental impact of the teacher today.

Thus, the professionalism of primary school teachers should be considered as a professionally organized positive pedagogical influence of the teacher on solving difficult situations, which provides him/her with a special socio-professional image among children, parents, colleagues and the school community.

\footnotetext{
${ }^{1}$ Протасова Н. Г. Гуманізація післядипломної освіти педагогів. К., 1998. 151 с.
} 


\section{The conceptualization of approaches in stimulating of professional self-improvement of primary school teachers: psychologically-pedagogical discourse}

We are talking about the special professional status of the teacher, about his indirect role between the state and society, in which he/she, on the one hand, forms a positive image of his state, and on the other consciously changes him/her in the process of teaching. Therefore, in order to determine the pedagogical concept of self-development of teacher's professionalism, it is necessary to distinguish the sphere of parity relations, to define priorities and to emphasize the focus. As I. Ziazun points out, this area of pedagogical design can be conditionally called pedagogical accentology, though it is not only about accents, but, in fact, ways of achieving integrity and harmonious interaction ${ }^{2}$.

Though such a conceptual approach to considering the very essence of the teacher's professional development is weakly supported by his practical activity, for which it has its own reasons.

First, the development of professionalism of primary school teachers occurs not only in complex socio-ideological conflicts, but also in the conditions of radical changes in the field of education, change of norms and moral values, considerable diversity of views and approaches to understanding the category of "professionalism".

Secondly, the personal achievements of the teacher are being evaluated recently outside the priority of humanism, kindness, citizenship, professional virtue, which is the basis of the teacher's professionalism.

Thirdly, such a situation makes it difficult to solve topical problems in training of primary school teachers in the conditions of higher education and in teacher training centers, in postgraduate pedagogical education institutions, which requires deepening of scientific research on this problem.

Thus, these obstacles to the development of teachers' professionalism, approaches in overcoming them are conceptual in nature; they affect the overall status and development of teacher professionalism.

\footnotetext{
2 Зязюн I. А. Гуманізм освіти XXI століття : філософський і психологічний аспект. Теорія $і$ практика управління сочіальними системами : щоквартальний науково-практичний журнал. 2002. № 2. С. 18-25.
} 
There is an objective need for a modern understanding of the professionalism of the teacher as a social phenomenon, which combines personal qualities, successful moral and intellectual and professionally expedient personal self-realization, professional excellence, which will allow to understand the essence of the process of stimulating professional development and self-development of professional competence, correctly identify the indicators and criteria for career growth ${ }^{3}$.

We consider the professionalism of the teacher as a qualitative-valued pedagogical category, which organically combines social activity, humanistic orientation and responsibility, in-depth and modern psychological and pedagogical knowledge, common moral values, pedagogical excellence, continuous work on professional self-improvement.

The proposed definition of professionalism changes the nature and content of his continuous professional self-improvement throughout its life, its purpose, goal orientation, peculiarities of teacher's interaction with people, especially with children, ways and means of successful advisable interaction, supported by society and subjects of pedagogical process.

It should be noted that the professionalism of the teacher is first of all a subsystem of social activity and social culture. Therefore, his/her study is multidimensional, it has axiological and acmeological character. The effectiveness of the teacher's professional self-development depends to a large extent on the prestige of the profession in the society, which mainly creates the basis for its intensive self-formation. But there are also many contradictions here.

It would not be hard to notice that in the field of view of modern education officials there was and is basically one element of teacher professionalism - the ability to impart intellectual knowledge and skills to children; the deep socio-pedagogical aspects and processes of pedagogical activity stay out of sight.

The analysis of variants of paradigmatic approaches, which define the teacher professionalism, shows that they do not exclude each other, but only complement each other, revealing its different sides.

Сущенко Л. О. Концептуальні засади саморозвитку професіоналізму вчителя. Педагогіка $i$ психологія формування творчої особистості: проблеми і пошуки : зб. наук. пр. / редкол.: Т. І. Сущенко (голов. ред.) та ін. Запоріжжя. 2007. Вип. 47. С. 315-320. 
We will attempt to complement the existing conceptual approaches with the perspective of another paradigm, which allows us to take a different approach to understanding the self-development of teacher's professionalism and the assessment of his/her pedagogical activity. It is about using the laws of new professional thinking in the process of forming the professionalism of teachers, connected with its conceptualization.

The need to conceptualize the process of forming a teacher's professionalism is explained by the global objective processes as they occur around the civilized world. These are, first of all, processes of dialogue and rapprochement of cultures and peoples. Progress in education and pedagogy should be directly measured by the quality of life and communication of each individual; the progress of pedagogical professionalism - the quality of life of each child. Therefore, modern education, civilizational pedagogical process should be understood as the convergence of teacher and child to the culture of civilization in different spheres of their life. This convergence should become a significant criterion for teacher professionalism today.

The core of civilization is culture as spiritual production and reproduction, and the deep foundation of culture, in turn, is the moral foundation and humanistic values of society.

So the question is: what kind of teacher professionalism is needed today to make children in the era of social transformation feel comfortable, think and act in all spheres of being under the canons of culture, so that their activity in history in improving the lives of each person and society is enhanced?

Thus, the professionalism of the teacher today has many new shades of manifestation: in constant scientific research, pedagogical skills, selfeducation aimed at personal professional self-development, in creating an educational environment that excites, amazes and develops the personality of the child, promotes the active self-identification of spiritual self-expression. 
The need for changes in teacher training in the system of postgraduate teacher education meets the challenges of the times, increasing demands and quality transformations in society, therefore, and important social and pedagogical issues. The society needs teachers who would accept the changes which are taking place in education, adapt to them, transform a new educational and philosophical paradigm and work meeting modern requirements. The knowledge gained from the higher education institution cannot predict all occasions, otherwise the imminent standardization of the pedagogical process, which really obstructs creative search. That is why the question of stimulating professional selfimprovement of primary school teachers in the system of postgraduate pedagogical education is urgent.

\section{Factors of influence on stimulation of professional self-improvement of primary school teachers in the system of postgraduate pedagogical education}

The stimulating function of the system of postgraduate education of pedagogues is to increase the interest of teachers in new knowledge, the organization of educational process on the basis of problemmethodological and search methods, which contribute to the dissemination of educational needs and diversify their interests, and not only professional ones. The system of postgraduate education is intended to stimulate selfeducation and self-development of teachers, in every possible way to encourage and support the specialist's desire for education, improvement and development.

Premising that the stimulating function of postgraduate education is the basis of our research, we consider it is necessary to highlight a number of factors of pedagogical influence on the stimulation of professional selfimprovement of primary school teachers. Based on the analysis of scientific sources, it is possible to determine the factors influencing the stimulation of professional self-improvement of teachers (Fig. 1). 


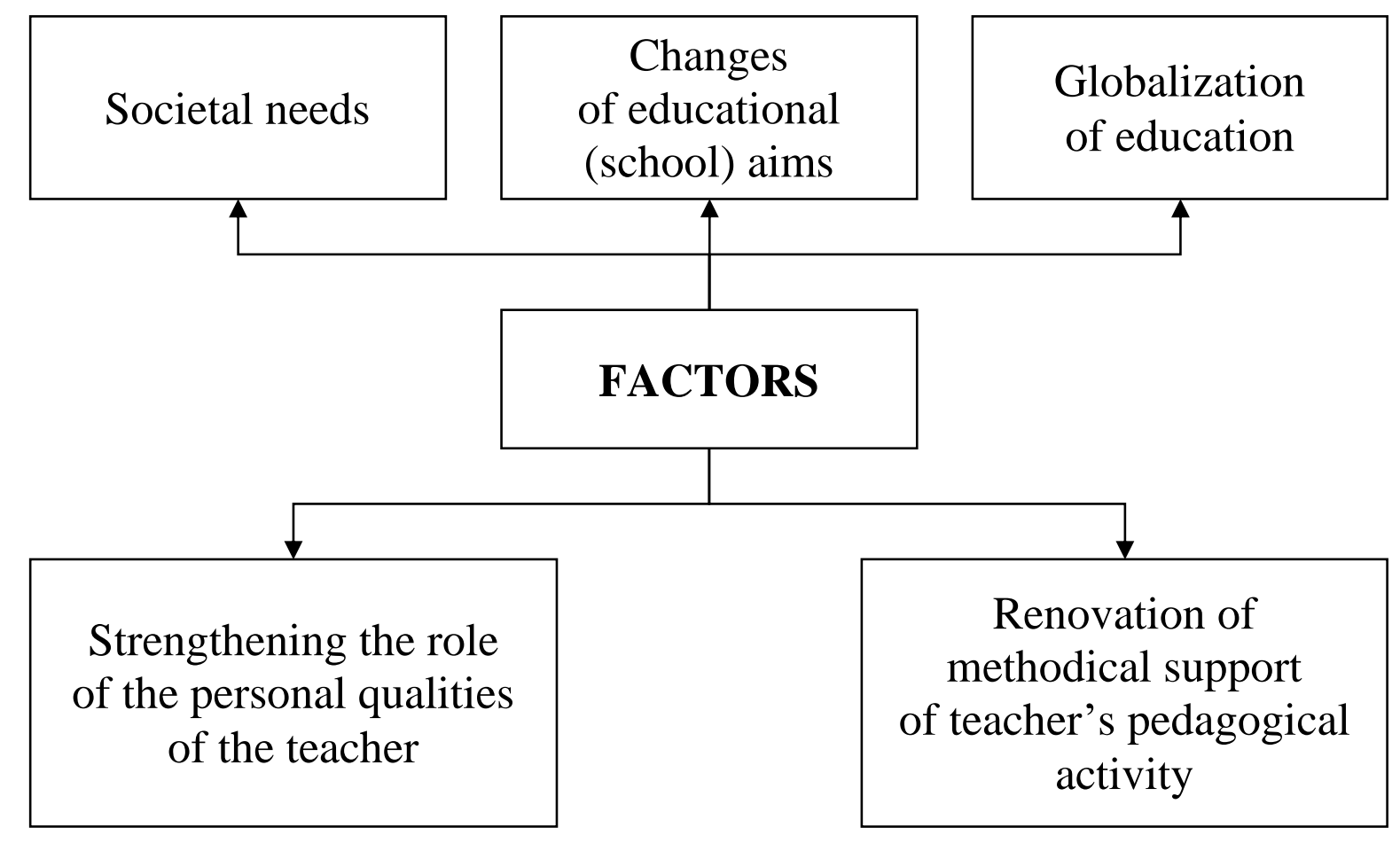

\section{Fig. 1 Factors of influence on stimulation of professional self-improvement of a primary school teacher in the system of postgraduate pedagogical education}

One of the factors can be called the needs of society, i.e. societal and social environment. Today, in times of change, the relevance of knowledge about a man, about the possibilities of its adaptation to the rapidly changing natural, socio-economic and cultural environment, dynamic changes in all spheres of social life is increasing. In today's society, many educators lack such qualities and knowledge as psychological and social readiness to live and work in new conditions, a willingness and ability to deal honourably with unusual and difficult situations, moral stability, and so on.

Becoming an individual is carried out within a context where the natural urge for self-affirmation and success faces ever-increasing competition and increased requirements on the individual in the labour market. Another set of personality traits is needed that enables a person to successfully integrate into a complex social environment: the ability to 
quickly learn a new one, flexibility, dynamics, mobility, the ability to take actions through trial and error.

With the transition to market relations and the democratization of the life of our society, the question of improving the training of teaching staff, the formation of new qualities in them, in particular, the ability to be a leader of the child in his/her self-knowledge, in self-development and especially in self-realization, has been raised. A general educational establishment needs a teacher-psychologist, a teacher-technologist, a teacher-researcher, who must be able to solve creative, high-level complex professional problems. Changes in the nature of teacher-tutor relationships with children are also important. The personality of the teacher is an effective factor in the formation of the pupil's personality. In actual practice, the teacher clearly demonstrates his/her learned behavioural patterns, social norms and values. His/her individual-psychological characteristics determine the values of the pupil. Educational potential of the teacher is not limited to his/her pedagogical technology, because he/she educates pupils, as noted by G. Kostyuk, "his attitude to learning, his organization, relations with pupils, communication with them, his erudition, wealth of spiritual interests, principle, justice, demands on students, as well as attentiveness, observation, understanding of each student's personality, sincerity in dealing with them" ${ }^{4}$.

Educators, by realizing themselves, give meaning the global values of the child. However, only that teacher successfully manages to this mission, who is constantly working on developing own motivation to master the spiritual culture, to deepen and diversify knowledge, focused on the systematic improvement of their professional skills.

Another important factor that not only actualizes professional selfimprovement, but also influences the process of its stimulating, is the globalization of education.

The integration process in science and education has two components: forming a commonwealth of leading European universities under the aegis

\footnotetext{
${ }^{4}$ Костюк Г. Навчально-виховний процес і психічний розвиток особистості. Г. Костюк. К. : Радянська школа, 1989. 608 с.
} 
of the document named the Great Charter of Universities (Magna Charta Universitatum), and the union of national education and science systems into the European space with common requirements, criteria and standards. The main purpose of this process is to consolidate the efforts of the scientific and educational community and governments of Europe to significantly enhance the competitiveness of the European science and higher education system on a global scale, and to enhance the role of this system in social transformation.

Today, it can be stated that, despite the natural achievements of education provided by the new socio-political system (democracy, flexibility, non-ideologization), education has become less qualitative in scale, and the overwhelming majority of graduates of higher education institutions are not competitive in the European labour market. This requires all to talk less about their own achievements and to analyze more the global and European trends in education reform, and according to this to improve own professional field of activity in a diligently and consistent way.

Another important factor is to change the aim (aims) of education, because it is one of the main tasks that the modern school faces.

Today our school is experiencing a difficult but extremely interesting period. New educational models and individual programs sometimes make one think of the "good old days" when the school education was cautiously restricted by stable curricula and provided with clear guidelines.

The appearance of courses for various innovative projects is quite natural: school should and can be as multidimensional and ambiguous as life itself. Alternative programs set new "spaces of opportunity" for children and teachers. However, the opportunity to choose and self-determination remains undesirable for educators, and sometimes it is a kind of annoying factor. The longing for methodological recommendations, a counterweight to some "traditional system of teaching" (which does not mean any particular model, but the very idea of stability, immobility, permanence of learning) makes one think that the flexibility of the teacher, his ability to real professional development is not 
at all depends on state-of-the-art technology (new programs or new equipment), and requires a certain level of formation of very specific abilities that would allow you to change, transform and create your professional style.

The extraordinary flexibility and dynamism of the school education system compels to put the problem of teacher training completely new. In this situation, the attempt to refocus pedagogical education from mastering individual technologies to forming a willingness to choose, learn and use technologies with a new orientation is extremely interesting. Self-determination, professional flexibility, initiative, open-mindedness to the new - all of them are not just individual features of professional activity, but a number of skills that are to be formed. In turn, such traditional characteristics of teachers, such as passivity, motivational weakness, rigidity, reflect non-possessing of specific technologies of transformation of their activity.

Obviously, teacher education should be based on the ideology of development (self-development). The model of teacher training must meet the time requirements and qualitatively change, both substantively and technologically.

O. Vasilyeva believes that professional development is inseparable from the personal: underpinning both is the principle of self-development that determines the ability of the individual to transform their own life in the subject of practical transformation, which is characteristic of the professional development of the teacher. Personal development involves a strategy of releasing inner resources, which include the ability to solve valued-moral problems and, when necessary, confront the environment, actively influence it, and assert its independence from external pressure and the possibility of creative expression. In professional development the teacher is characterized by the ability to see his professional work in its entirety. This provides the teacher with the opportunity to internally accept, understand and evaluate the difficulties and contradictions of the pedagogical process, independently to constructively resolve them in accordance with their value orientations, to consider the difficulties as an 
incentive for further development, as well as overcoming their own boundaries. The teacher's awareness of his potentials, personal and professional growth prospects encourages him to constantly experiment, which is understood as creativity, choice, and search. The leading element in such a situation of teacher's professional development is the ability and need to make choices, to feel his freedom, on the one hand, and his responsibility, on the other ${ }^{5}$.

In our opinion, self-development can only be talked about in cases when the teacher is aware of his involvement and responsibility for everything that happens to him, his pupils (and the school as a whole), and tries to actively promote or counteract external circumstances, plan and set goals of professional activity, to change oneself for achievements. This model is the most productive for the creative realization of the teacher's personality. Creative work, when the actions of the teacher are not composed on a pattern, requires for the successful implementation of a strong, mature, flexible personality, and most importantly, the ability to think independently goals and objectives that most often do not coincide with the common in this school (education system), to strive to achieve. Therefore, everything that contributes to personal and professional self-improvement extends the capacity for creativity.

Another factor of pedagogical influence on stimulation of professional self-improvement of the teacher we consider strengthening of a role of personal qualities of the teacher. The provision is not in the "methodical tricks", but in the process aimed at "awakening" the desire for development and creating the conditions for active professional self-realization.

The analysis of primary sources, historical and pedagogical literature, and researches of scientists concerning the question of personal and professional qualities of the teacher allows to state that the teacher should possess such qualities as responsibility, respect for the personality of the child, colleagues, parents, kindness, tolerance, truthfulness, empathy,

\footnotetext{
5 Васильєва О. А. Професійна діяльність вчителя і основи самореалізації. Педагогіка $і$ психологія формування творчої особистості : проблеми і пошуки : зб. наук. пр. Київ ; Запоріжжя, 2006. Вип. 37. C. 83-90.
} 
gumption, endurance, self-control, principle, decisiveness, justice, efficiency, organizational skills, self-criticism, self-esteem.

M. Borytko identifies three key qualities that are factors of becoming a teacher: reflection, professional consciousness and professional selfesteem. The latter has two manifestations - self-esteem of the result and self-esteem of the potential and the factor of professional development is the combination of low self-esteem of the result with high self-esteem of one's own potential ${ }^{6}$.

Along with the mentioned personal and professional qualities, which have been determined by the teacher for many centuries, the urgent problem of our dissertation is the study of the qualities necessary for one's own professional self-development. In the context of this provision, two models of pedagogical work are distinguished:

1. A model of adaptive behaviour based on adaptation processes. The teacher working on this model is trying to conserve one's energy developed algorithms for performing professional tasks, turning the pedagogical activity itself into a template and stereotyped one.

2. A model of professional development based on the teacher's awareness of his/her own opportunities and perspectives for professional and personal development ${ }^{7}$.

A contemporary understanding of professional self-development is based on the thesis of the need for awareness of the individual as a subject of initiation of his own activity. In this context, the function of the leading characteristics of the personality is fulfilled by such personal and professional qualities as initiative, creativity, responsibility, self-actualization, self-esteem, self-control, self-observation, self-monitoring, self-determination, self-reflection (self-awareness, self-projecting) and so on.

Let us consider the basic concepts. The first part of the compound words "self-" means: first, the focus of action on oneself; secondly, performing the action without assistance.

\footnotetext{
6 Борытко Н. М. Педагог в пространствах современного воспитания. Науч. ред. Н. К. Сергеев. Волгоград : Перемена, 2001. 214 с.

Митина Л. М. Личностное и профессиональное развитие человека в новых социальноэкономических условиях. Вопросы психологии. 1997. № 4. С. 28-39.
} 
Self-esteem is an assessment of oneself, one's abilities, qualities and place among other people. Self-esteem is an important regulator of behaviour. Self-esteem depends on the relationship of the person with others, its criticality, requirements to itself, attitude to successes and failures. Thus, self-esteem affects the effectiveness of activities and the further development of the individual. Self-esteem requires that the individual examine its behaviour or thinking and determine if they are changing.

Self-monitoring is a procedure by which a teacher monitors his or her pedagogical activity and behaviour. Self-monitoring involves self-analysis of activities, current self-correction, allows determining the level of achievement of a goal at a particular stage of activity and is an admission to the following actions.

The ability to reflect, that is, to exercise self-observation, self-analysis, self-esteem, self-control, self-monitoring, self-motivation, defines a teacher as an employee who carries out his pedagogical activity on the basis of his understanding. Such an educator draws lessons from his experience and projects the impact of his own achievements on future professional activity. His/her reflections help to find out if the goal of the activity has been achieved; to identify positive and negative changes in the educational process; to determine whether the methods used in the educational process were not only influential but also justified; whether the predictions of the activities he/she did were precise. Promoting these reflective steps is a difficult task - it takes time to think. Nevertheless, this understanding should occur and be fruitful for the teacher himself and for the education process as a whole. At the same time, favourable conditions are created for the adaptation of the professional interests and needs of the individual teacher to the purpose of the educational institution, to the requirements of management, which is a real force that should be taken into account. As a result, the teacher focuses on the tasks of professional activity within the boundaries based on a dialogue by the unique "I" of his personality. 
Building a professionally-pedagogical activity based on reflective processes has some advantages, namely:

- gives the teacher the opportunity to manage their own behaviour, relationships with other participants in the educational process, pedagogical activities;

- helps to develop responsibility for the consequences of their actions, fulfilment of responsibilities;

- provides personality changes at the behavioural and positional levels;

- develops the ability to make alternative decisions regarding specific pedagogical situations, to choose between rational and irrational, to listen to their own conscience;

- expands opportunities for the realization of a unique "I" of the teacher in practical experience, its development and asserting in the teaching staff and educational space.

The basis of professional self-development is personal selfdevelopment, aimed at developing the creative personality of the teacher. It should be noted that self-development is a person's desire to discover, realize and improve his or her personal qualities. We consider this process as the formation and integration in the pedagogical activity of personal, professional qualities and abilities, methodological, methodical, research knowledge and skills, but the important thing is the active qualitative transformation of the teacher of his inner world, which leads, in fact, to self-actualization and realization of his creative potential. This process is ensured by a certain technology.

The main purpose of the technology of professional self-improvement of the teacher developed by us is realization of a complex of means and conditions that provide formation of the position of teacher-researcher, the increase of cognitive level of personality, its value attitude to innovative and research activity, the realization of creative potential in the process of professional self-development, the formation of the system of analytic and reflexive skills, self-esteem, introspection, reflection and self-reflection of one's own professional level. Summarizing the above, we formulate at 
least as the important factor of pedagogical influence on the professional self-improvement of the teacher - updating of methodological support of pedagogical activity of primary school teachers depending on the stages of their professional formation and development.

Using these theoretical foundations, we consider it would be appropriate to highlight the five hypothetical stages of becoming a professionally-personal self-improvement of educators: adaptation (teacher-specialist, practitioner) $\rightarrow$ differentiation (teacherexperimenter) $\rightarrow$ individualization (teacher-innovator) $\rightarrow$ sustainable self-development (teacher-innovator) $\rightarrow$ self-actualization (teacherresearcher). Each stage is characterized by a special set of factors and conditions that stimulate the teacher's professional and personal development.

We believe that the stage of adaptation is characterized by the need for stimulation and facilitation by institutions of postgraduate pedagogical education and school. The pedagogical goals at this stage are global or blurred, the formation of professional self-awareness, the formation of selfesteem, the processes of self-organization, self-government, self-correction of former stereotypes and ideas are actualized; the interest in the subjects of the pedagogical cycle is actualized, pedagogical activity has a "cumulative" character; as a rule, traditional forms, techniques, methods and tools of teaching are used; there is a formation of practical reflection, the teacher is "inside" the activity, absorbed by the process of its implementation and "sees" it in a fragmented manner. Interaction with colleagues, students, parents, administration, methodologists, non-standard situations in lessons, performing pedagogical tasks when it is used different role positions, motivation for professional success, high level of cognitive activity, awareness of the need to "be meaningful", striving for self-improvement, this is a condition of transition of a teacher-specialist to the differentiation stage.

The differentiation stage is characterized by manifestations of individual uniqueness and is expressed by the degree of development of such qualities as creativity, criticality, formation of methodological 
reflection, strengthening of research orientation; desire to analyze pedagogical problems, facts and phenomena, study of methodology and methods of pedagogical researches. At this stage the technique of teaching the subject is improved; activity is planned and carried out on the basis of knowledge of pedagogical theory and didactic patterns; basic researches are carried out on the basis of plans of research experimental work; the need for personal and professional self-actualization is actualized, the teacher absorbs the position of the experimenter. Increasing cognitive activity, the need for professional and personal self-expression, the formation of creative self-awareness, goal setting, peer review and analysis of colleagues' lessons and own lessons are factors that contribute to the transition of the teacher to the individualization stage.

The individualization stage in the professionally-personal self-development of the teacher is characterized by the formed creative self-awareness, adequate self-esteem, stable skills of self-organization and self-government; the teacher absorbs the position of the innovator - the initiator and implementer of own ideas and pedagogical developments; there is a need for critical analysis and generalization of pedagogical facts, phenomena and processes, mainstreaming of activity for monographic study of one's innovative experience, creation of an "innovative school", development of author's programmes and teaching methodological complexes; technological reflection is developing. The teacher-innovator differs in the qualities of the master and at the same time brings in the work new forms, methods, tools that increase the efficiency of the pedagogical process. Variety of performed pedagogical tasks, interaction with consultants (academics of postgraduate education institutions, universities, methodologists), professional success, opening and realization of creative potential - these are the conditions that contribute to the transition to the stage of sustainable self-development.

The stage of sustainable self-development is characterized by the desire for scientific substantiation of own professional activity, the need to master philosophical, methodological, technological knowledge; the 
teacher moves into the position of an innovator, a complex, systematic activity of whom is aimed at the search, creating and implementing educational innovations that change or update the technology of pedagogical activity and provide personal self-development: ways of organization of educational materials, means of preparation and educational activity of the teacher, elements of educational content, educational content plans and programmes, forms of education, etc. There are organization and improvement of innovative activity, approbation of innovations, scientific-methodical reflection, discussion and review of various pedagogical projects, educationally-methodical complexes, participation in scientific-practical pedagogical conferences, seminars and colloquiums. Forming a "bank" of innovative pedagogical information, unleashing and realizing creative potential are the conditions that contribute to the formation of a teacher-researcher and ensure the transition to the self-actualization stage.

The self-actualization stage is characterized by pedagogical creativity and ability to construct (design and authorship) in creating a conceptual image (model) of pedagogical activity; includes the most complete personal and professional self-realization, development of methodological reflection, awareness and acceptance of humanistic values, creation of own school of the teacher-researcher ${ }^{8}$.

\section{CONCLUSIONS}

Thus, the stimulation of professional self-improvement in our concept transcends the classical aspects of the teacher retraining and is combined with research, scientific and methodological work, and the universalization of professional functions. A special feature of the concept is its focus on stimulating the continuous professional self-improvement in organic unity, continuity and consistency of influence on this process of interaction of the system of postgraduate pedagogical education and school.

\footnotetext{
8 Демічева І. О. Технологія формування дослідницької культури вчителя. Педагогіка $і$ психологія формування творчої особистості : проблеми і пошуки : зб. наук. пр. / редкол. : Т. І. Сущенко (голов. ред.) та ін. Запоріжжя, 2004. Вип. 32. С. 106-112.
} 
In general, the ideas discussed above allow us to draw the following conclusions:

- professional self-improvement of the teacher is considered by researchers in the context of mutual influence of his individual characteristics and socio-cultural environment in the process of socialization and professionalization;

- we suppose the tasks of institutes of postgraduate pedagogical education should not be to directly influence the personality of a self-developing teacher in order to achieve the desired results in the formation of a positive motivation for continuous professional selfimprovement, but in creating the necessary psychological and pedagogical conditions for one's self-building, in stimulating the mechanisms of one's professional self-knowledge, self-acceptance and self-prediction;

- realization of stimulating function of postgraduate pedagogical education - taking into account individual abilities, capabilities and potentials of a specialist; his/her professional experience; needs of mass pedagogical practice; a comprehensive approach to the organization and implementation of continuous professional training of pedagogical staff;

- building and designing a dynamic strategy of personal and professional self-development and self-improvement of teachers aimed at a qualitatively new high level of performing professional tasks on a moral and ethical basis; the sustainable development of professionally-important and personal competencies; the orientation for a high professional achievement with a pronounced desire for a creative search, after all, to be the creator of own professional status, image and prestige.

\section{SUMMARY}

The conceptual bases of the process of stimulating professional selfimprovement of elementary education teachers in the system of postgraduate pedagogical education are presented. It has been found out that modern postgraduate education, which mission is to train highly qualified, competitive, mobile-informed specialists, plays a determining role in solving the problem of lifelong learning. 
The attention is drawn to the fact that the professionalism of primary school teachers should be considered as a qualitative-valued pedagogical category, which organically combines social activity, humanistic orientation and responsibility, deep and modern psychological and pedagogical knowledge, universal human moral values, pedagogical skills, uninterrupted work on professional self-improvement. The proposed definition of professionalism changes the nature and content of one's continuous professional self-improvement throughout one's life, one's purpose, the goal orientation, peculiarities of teacher's interaction with people, especially with children, ways and means of successful, supported by society and subjects of pedagogical process and an appropriate interaction.

It is noted that the society needs teachers who would accept the changes taking place in education, adapt to them, transform them into a new educational and ideological paradigm and work at the level of time requirements.

Based on the outlined conceptual positions, the factors of influence on the stimulation of professional self-improvement of primary school teachers in the system of postgraduate pedagogical education are determined, in particular: the needs of the society, changing the goals of education and its globalization, enhancing the role of the teacher's personal qualities, updating methodological support for teacher's pedagogical activity.

It is found out that in order to understand the relevance and scientifictheoretical statement of the problem of lifelong learning, the necessary preconditions and methodological guidelines are necessary, namely: the idea of subjectivity; the idea of the uniqueness and originality of the inner world of human; the idea of self-actualization of the individual as the highest form of self-development. On the basis of theoretical analysis it is established: a dynamic strategy of personal and professional self-development and selfimprovement of teachers should be aimed at a qualitatively new high level of performing professional tasks on a moral and ethical basis; the sustainable development of professionally-important and personal competencies; the orientation for high professional achievements. 


\section{REFERENCES}

1. Протасова Н. Г. Гуманізація післядипломної освіти педагогів. K., 1998. $151 \mathrm{c}$.

2. Зязюн I. А. Гуманізм освіти XXI століття : філософський i психологічний аспект. Теорія $i$ практика управління сочіальними системами: щоквартальний науково-практичний журнал. 2002. № 2. C. $18-25$.

3. Сущенко Л. О. Концептуальні засади саморозвитку професіоналізму вчителя. Педагогіка $i$ психологія формування творчої особистості: проблеми і пошуки : зб. наук. пр. / редкол.: Т. І. Сущенко (голов. ред.) та ін. Запоріжжя. 2007. Вип. 47. С. 315-320.

4. Костюк Г. Навчально-виховний процес і психічний розвиток особистості. Г. Костюк. К. : Радянська школа, 1989. 608 с.

5. Васильєва О. А. Професійна діяльність вчителя і основи самореалізації. Педагогіка $i$ психологія формування творчої особистості : проблеми $i$ пошуки : зб. наук. пр. Київ : Запоріжжя, 2006. Вип. 37. С. 83-90.

6. Борытко Н. М. Педагог в пространствах современного воспитания. Науч. ред. Н. К. Сергеев. Волгоград : Перемена, 2001. 214 с.

7. Митина Л. М. Личностное и профессиональное развитие человека в новых социально-экономических условиях. Bonpocbl психологии. 1997. № 4. С. 28-39.

8. Демічева I. О. Технологія формування дослідницької культури вчителя. Педагогіка і психологія формування творчої особистості : проблеми і пошуки : зб. наук. пр. / редкол. : Т. І. Сущенко (голов. ред.) та ін. Запоріжжя, 2004. Вип. 32. С. 106-112.

\section{Information about the author: Sushchenko L. O.}

Doctor of Pedagogic Sciences, Associate Professor, Professor at the Department of Education and Management, Classic Private University 70-b, Zhukovskoho str., Zaporizhzhia, 69002, Ukraine 


\title{
PEDAGOGICAL RESOURCE OF FORMATION OF PROJECT TECHNOLOGICAL CULTURE FOR TEACHERS OF TECHNOLOGY
}

\author{
Slabko V. M., Makarenko L. L.
}

\section{INTRODUCTION}

To identify cultural-historical and pedagogical research resource of designed technological teachers' culture it is considered the theoretical works that model the real pedagogical concepts for development and justification of these models, for the sake of study of the secrecy of the approach to pedagogy, performed under the leadership of Nychkalo N. H. the work of Gineczinckij V. I. ${ }^{2}$, who first suggested treating pedagogy as a projection, introducing and analyzing the functioning of a pedagogical system with a special purpose. Examples of diligent elaboration of the theoretical models can be found in the work of Ball G. A. ${ }^{3}$, Sydorko V. P., Tverezovska N. T. ${ }^{4}$, Bereziuk O. S. ${ }^{5}$, Clactenyn V. A. ${ }^{6}$, Cerykov V. V..

All in one pedagogical cuts bring categorically fixed conceptual transitions through the theoretical models to practical testing. The purpose of such work is revealed in general and briefly focused in the central category, around which the synthesis of the theoretical ideas and practical methods occurs. The names of these same central categories are denoted and the corresponding theoretical models (B. Z. Vylfov, I. P. Ivanov, V. A. Kan-Kalyk, Kh. Y. Lyimetc, T. N. Malkovcka, A. V. Mydryk,

\footnotetext{
${ }^{1}$ Nychkalo N.H. Rozvytok profesiinoi osvity $\mathrm{v}$ umovakh hlobalizatsiinykh ta intehratsiinykh protsesiv: monohrafiia. - K.: Vydavnytstvo NPU imeni M.P. Drahomanova, 2014. - $125 \mathrm{~s}$.

${ }^{2}$ Gineczinckij V. I. Ocnovy' teoreticheckoj pedagogiki : ychebnoe pocobie. - CPb., 1992. $-325 \mathrm{c}$.

${ }^{3}$ Ball G. A. Teoriya ychebny’x zadach. - Mockva : Pedagogika, 1990. - 184 c.

${ }^{4}$ Sydorko V. P., Tverezovska N. T. STRUKTURA I FUNKTsII MIZhPREDMETNYKh ZVIaZKIV ॥ Visnyk Natsionalnoho universytetu oborony Ukrainy 5 (42) /2014. S. 157-161.

Bereziuk O.S. Metodyka poetapnoho upravlinnia protsesom modeliuvannia pedahohichnykh sytuatsii // Profesiina pedahohichna osvita: innovatsiini tekhnolohii ta metodyky: Monohrafiia / Za red. O. A. Dubaseniuk. - Zhytomyr : Vyd-vo ZhDU im. I. Franka, 2009. - S. 377-390. C. 36 .

${ }^{6}$ Clactenyn V. A., Podymova L. C. Pedahohyka: Ynnovatsyonnaia deiatelnoct. - Mockva : Mahyctr, 1997. -

${ }^{7}$ Cerykov V. V. Obrazovanye y lychnoct. Teoryia y praktyka proektyrovanyia pedahohycheckyx cyctem. Mockva : Lohoc, 1999. - 272 c.
} 
L. I. Novikova, N. F. Radionova, A. P. Triapitsyna, H. I. Shchykina etc.). We have been analyzed studies of interdisciplinary links in studies and integration of educational objects (Yu. I. Dik, V. N. Makcymova) work related to problems of choice of methods and pedagogical research and decision-making in real practice of learning and nurturing (Yu. K. Babanckyi, Z. I. Vacylieva, M. Ya. Vilenckyi, B. C. Hershynckyi, I. Ya. Lerner, C. A. Racchetyna, M. N. Ckatkina, O. V. Titova); numerical separate methods and cyclical tendencies of their generalization (I. P. Ivanov, V. A. Izvozchikov, A. H. Olneva); works related to the valuable aspects of pedagogical activity and pedagogical development, insofar as the value of the direct-technological culture is determined by the price criteria alone (C. H. Vershlovckyi, V. V. Horshkova, A. P. Triapitsyna).

In this way, in the pedagogical science there are serious grounds for general theoretical, systematic and methodological, analitic, value-oriented orders for the development of a methodological system for the formation of direct-technological filters. However, any attempts to link these heuristic frontiers as well-known theoretical estimates of formation and development of direct-technological filters haven't been worked out yet.

We revert to some of the centers of pedagogical practice, which testify about the necessity of justifying the phenomenon of direct-technological culture.

As early as in the 70's of the XX century, the students pointed to the pursuit of a component in the activity of a teacher. This is most pronounced in the work of Kyzmyna $N . V .^{8}$, where the specified component has been removed on the basis of sequential usage of the systematical approach.

Zahviazynckyi V. Y. ${ }^{9}$ draws more attention to heuristic, creative side of the future teacher's activity. In this case, the author, from one side, speaks about the necessity of rational reconstruction of the three-posterior

\footnotetext{
${ }^{8}$ Kyzmyna N. V., Hynetsynckyi V. Y. Aktyalnye problemy profeccyonalno-pedahohycheckoi podhotovky ychytelia // Covetckaia pedahohyka. - 1982. - № 3. - C. 63-66; Kyzmyna N. V. Ocherky pcyxolohyy tryda ychytelia: pcyxolohycheckaia ctryktyra deiatelnocty ychytelia y formyrovanye eho lychnocty. - Lenynhrad : LHU, 1967. - $184 \mathrm{c}$.

${ }^{9}$ Zahviazynckyi V. Y. Pedahohycheckoe tvorchectvo ychytelia. - Mockva : Pedahohyka, 1987. - 160 c.
} 
teacher and in this contact he mentions during projecting, but with another, - does not breed between the group of projecting, planning and projecting, sees in them a single flow of three-fold. Consequently, while pedagogical twist and practice are interrupted, according to the classification of Zahviazynckyi V. Y. at the level of improvement of the invention, it is unlikely that rational reconstruction of practical pedagogical activity is possible.

Until the mid-1980s, there was only one concept - "enforceable" correlating theory and practice, but from the beginning of the 80's onwards, innovative innovations initiated by teachers and innovators began to emerge (I. P. Volkov, E. N. Ilin, C. N. Lycenkova, V. F. Shatalov). In order to expand the experience of newcomers, the needs were revealed in the systematic review of the entire educational environment of the colored yacht. First of all, the practical needs revealed during the rational reconstruction of the work of newcomers have been pointed out by L. M. Frydman ${ }^{10}$.

The works that have emerged over the years have been the authors who came up with the idea of a wholly practically implemented pedagogical system. To this end, V. A. Karakovckoho and M. P. Shchetynina are identified as distinguishing the projective component of practical pedagogical activity as a self-directed type of activity.

It is important to note that innovative, practice-initiated learning experiences start with not just schools and not just learning. The higher needs of the higher school, both in the system of extracurricular and in the system of pupils, appeared in the projective needs.

The third aspect of the review of modern pedagogical activity is that it allows revealing the problems of pedagogical projection and project technological culture is social culture.

Evolution as a sphere of filters cannot be subjected to dynamic loads from the side of rapid-flowing and historical cultural and social-economic flows.

\footnotetext{
${ }^{10}$ Frydman L. M. Pedahohycheckyi opыt hlazamy pcyxoloha. - Mockva : Procveshchenye, 1987. - 224 c.
} 
Beginning in the 70s of the XX century, the researchers have pointed more strongly to the crises in the outbreak (F. H. Kymbc). In doing so, attention is drawn to the contradictions between the growing value of color and its underestimated social effect; between the formal receipt of a human being in the blossoming process of knowledge and the formation of a cultural, torsional and social responsibility, he contradiction between the traditional "strategy of preparation", which is the perfect work in the way of different stewardship of economic means, ecological terms and social structures, and blossom in fuller and deeper meanings of this word that reveals all the richness of person's potential that changes all the time. The researchers consider these contradictions to be global and dedicate a great deal of their work to them (K. Anhelovckyi, Dzh. Botkin, L. P. Byieva, V. P. Zinchenko, I. C. Kon and T. Khiucen)

Withdrawal of the indicated arguments is possible only in the way of a new prudent decision. The twentieth anniversary is differentiated by such an initiative in all worlds. The most prominent of them are the UNECCO Lifelong Education ${ }^{11}$ concept and the corresponding works on continuous evaluation of V. C. Vladyclavlieva, V. H. Onyshkina ${ }^{12}$ and Yu. N. Kyliutkina $^{13}$, B. C. Hershynckoho ${ }^{14}$ In the eightieth years of the twentieth century, new concepts of coloring appeared in the world. For example, in the USA, this is the report of the Gardner Comic and America 2000 ${ }^{15}$, Sweden - T. Khiucena ${ }^{16}$ project; in the CRCR - these are two alternative concepts, prepared by RASC "Base School" and the Presidium of the CCCR AES.

However, all of these initiatives had features that were only ecofriendly in terms of models of desired change. They need the right solution,

\footnotetext{
${ }^{11}$ ЮНЕСКО и развитие образования взрослых // Перспектива. Вопросы образования. - 1982. - № 1-2. C. $137-145$.

${ }^{12}$ Onyshkyn V. H., Kyliutkyn Yu. N. Neprerbvnoe obrazovanye - pryorytetnoe napravlenye nayky // Covetckaia pedahohyka. - 1989. - № 2. - C. 86-91.

${ }^{13}$ Kyliutkyn Yu. N., Cyxobckaia H. C. Modelyrovanye pedahohycheckyx cytyatsyi. - Mockva : Pedahohyka, 1981. -207 c.

${ }^{14}$ Hershynckyi B. C. Fylocofyia obrazovanyia: naychnыi ctatyc y zadachy // Covetckaia pedahohyka. 1991. - № 4. - C. 69-74; Hershynckyi B. C. Fylocofyia obrazovanyia dlia KhKhI veka: (V poyckax praktykooryentyrovannых obrazovatelnыx kontseptsyi) . - Mockva : Covershenctvo, 1998. - 608 c.

${ }_{15}^{15}$ America 2000: an Education Strategy. - V. S. Government printing office, 1991. - 66 p.

16 Khiucen T. Obrazovanye v 2000-m hody: yccledovatelckyi proekt ; per. co shved. E. M. Cokolova. Mockva : Prohrecc, 1977. - 343 c.
} 
the adjustment to it, but they move little constructive material, and they are not sufficient for practical realization, they do not have the necessary for revisions to the level of a specific educational system. At the same time, however, these works move to low cost points of departure for our study.

Each of the three recycle leads our problematic pedagogical projection and direct techno graphic filters. In each of these recirculations it is possible to concentrate, first and foremost, to be required in pedagogical projection as a separate activity and to cemiotic processes, secondly, the whole circle of consideration of the projecting and the direct technographic filters, and also the corresponding means and technologies.

Having set out to disclose the conceptual estimates of the formation of direct technological filters, we cannot get past the logical and methodological inevitability of the inverse to the generic concept of "projection", this will allow us to further integrate this conception into the general and cultural and cultural and historical experience of the emergence and formation of direct technological culture. We will act as soon as we develop to transform this situation into another, more acceptable", Caimon H. ${ }^{17}$ says, in a nutshell. It is not necessary to transform the quotations, to create complex objects and structures, to develop algorithms of actions, to plan stages of reaching a certain goal. The engineer is looking for ways to increase the efficiency with the device or more relevant material for the new contraction; the doctor determines if the patient has received assistance; economy develops a plan for the collapse of the enterprise; the manager is ready for his or her own injection; the politician creates programs of social transformations; the teacher selects materials for the future; after all, many of our daily schedules are planned for the next day (weeks, months, etc.).

All these actions have an intellectual character, these operations with signs, models. From the similar actions, there is a peculiar mechanism of the filtration solution, which lies in the evaluative phenomena of "projection". The action of mechanism is to inform the preparation of some changes, to the forefront of these changes.

${ }^{17}$ Caimon H. Nayky ob yckycctvennom. - Mockva : Myr, 1972. - 147 c. 
In our study, we emerge from the interpretation of the filter as a specific human activity ${ }^{18}$. Speaking of "activity", we see this system of supra-biological means of human activity ${ }^{19}$ that are revealed through the inclusion of humans in social cells. First of all, this system of flaws is volatile. With the change of material production, the development of the cynical forces of man, his self-realization, are changed and delineated by them. The person acquires the experience of a third activity, which is socially significant in its cynicism and aimed at the manifestation and change of the color in which the person lives. From these kinds of people, norms and values are created, which are then included in social memory. Reflection of a distinct lineage of information that "superimposes" over a genetically predetermined one is transmitted through social relations ${ }^{20}$.

Speaking about filters, we cannot mention the characteristics of organizational types corresponding to its historical stages, which B. A. Нікітін ${ }^{21}$ is specialized in; corporative-remicnichy (sample and recipe of his opening); professional or scientific (theoretical knowledge and text formats) and direct-textual (projects, programs, and technologies).

The researchers ${ }^{22}$ distinguish between canonical and direct-technological filters, distinguishing between the applied pre-existing texturizes and the present-day ones, as it begins, starting with the Renaissance epoch, cyclical cells, the exact technological nature by its meaning.

In archaic culture, the phenomena and the practical actions of the mycelium as one whole: the idea passed the action, the action created the ground for the emotional phenomena. Then, in the old Egyptian and Shimmering-Babylonian culture, the manifestations of the phenomena

\footnotetext{
${ }^{18}$ Arnoldov A. Y. Teoryia kyltyry: Yctoryzm y voprocy metodolohyy // Kyltyra, chelovek y kartyna myra. Mockva : Nayka, 1987. - C. 5-27; Эkolohyia cheloveka: ocnovnye problemy. Cbornyk naychnyx trydov. Mockva : Nayka, 1988. - 222 c.

19 Эkolohyia cheloveka: ocnovnye problemy. Cbornyk naychnyx trydov. - Mockva : Nayka, 1988. - 222 c.;

${ }^{20}$ Cemenova N. N. Nayka kak yavlenye kyltyry // Nayka y ee mecto v kyltyre. - Novocybyrck : Nayka, Cyb. otdelenye, 1990. - C. 51-58.

21 Nykytyn V. A. Orhanyzatsyonnye typy covremennoi kyltyry : avtoreferat doktora kyltyrolohyy : 24.00.01 - teoryia kyltyry. - Toliaty - Mockva, 1998. - 49 c.

${ }_{22}$ Kantor K. M. Opyt cotsyalno-fylocofckoho obъiacnenyia proektnyx vozmozhnoctei dyzaina // Voprocy fylocofyy. - 1981. - № 11. - C. 84-97; Nykytyn V. A. Orhanyzatsyonnye typy covremennoi kyltyry : avtoreferat doktora kyltyrolohyy : 24.00.01 - teoryia kyltyry. - Toliaty - Mockva, 1998. - 49 c.; Novykov A. M., Novykov D. A.»Metodolohyia. - Mockva : CYNTEH, 2007. - 668 c.; Cydorenko V. F. Henezyc proektnoi kyltyry // Voprocy fylocofyy. - 1984. - № 10. - C. 86-99.
} 
begin to detract from practical action. However, all kinds of ancient human activity have been inextricably linked to myth as a distinctive worldview. Mythological information is not intersecting natural and patchy, alive and inanimate. This is the only place where there is no boundary between the possible and the effective. From one side, these are transformed, converted, but still reflect the activity, and from the other - the reduction of moral norms, regulative practice. Myth is the canon of activity. Canon is a guarantee of the effectiveness of every case. Any projective actions - these are not very specific operations on the initial material, but also some action, complete ritual idea connected through myth space with outer space. Every action is a corollary to a single whole of rational moments and irrational experiences. Myth is a peculiar kind of worldview, specific, figurative, sensual, syncretic manifestation of the phenomena of nature and cyclic life ${ }^{23}$. Myth is the expressed knowledge of the world in the epoxy of mythological thinking ${ }^{24}$. Myth was the real space in which the scattering of the mind and action of man. Thus, in the myth, one can see the origin of the cell on the transformation of human phenomena through the final product of their actions and efforts, and also through the completion of the operation. So, there are reasons to speak about the exact function of the myth, which is hidden in the canonical filter ${ }^{25}$.

At times of antiquity, the attitudes toward myth are gradually changed as to the dominant form of cyclopic consciousness. For the sake of rational estimation of mythical materials, mycillites were taught to abstract, logically.

There is a gradual difference from the mythological explanations and images and the formation of the philo-sophistic thinking style, based on the rational marking. The most important achievements of the ancient Greek philosophers include: the ability to soak in concepts, to exert them, and to cure them in the plane of "pure thought". In this way, it is possible to remove the rational reasoning from the canvas of practical experience. In

\footnotetext{
${ }^{23}$ Keccydy F. X. Ot myra k lohocy. - Mockva : Mыcl, 1972. - 198 c.

${ }^{24}$ Holocovker Ya. Э. Lohyka myra. - Mockva : Nayka, 1987. - 218 c.

${ }^{25}$ Acmolov A. G. Pcixologiya lichnocti. - Mockva : MGU, 1980. - 367 c.
} 
culture, practice and scientific knowledge already belong to two-level, principally different, logical actions, and where complex problems of their interrelation arise. Aristotle in "Metaphysics" writes about the fact that, in fact, the purpose of knowing knowledge is icine, and the purpose of knowledge, which is developing activity, is the right: after all, people are active even then, when they consider things, what they are, they do not come forever, and things in her relationship are now and then. It is there that we find valuable and valuable breeding of science and practice. In the mind of Aryctotel, he who holds the art [is considered] wiser than he who has the nerve, the sitter - the wiser than the artisan, and the arts are beyond $\operatorname{sight}^{26}$. It is important to emphasize that the "vertical" scale of values is assigned, if the "knowledge of reasons" is higher than the "ability to act" and the "knowledge, not reversed to gain benefits", is higher than the need for "beyond".

The "people of nature", the artisans, considered their activity as a kind of art, enshrined in the Greek notion "techne". A combination of "techne" and a combination of natural and pragmatic, pragmatic and ethical in it. The works are "techne". According to the statements, the "techne" cannot be transmitted from person to person without direct access. The transmitted may be the knowledge of either, as obtained in the result of "techne". The "techne" is typed, passed through, through a practical imitation. Responses of similar convictions came to us in the form of English type tenses: "A blacksmith has no need of an axe".

The Middle Ages are becoming an epoch of canonical culture. The world is a harmonically organized unity, and in this whole unity there could not be any corporeal change. At that moment, re-activation restores the unity of knowledge and actions and measures to the extent that the restoration of the filter is more and more cynical.

Such language is authoritarian. The recipe does not have an author. The author is a tradition that is slowly composing, a fourth-rate evolution, gradually becomes valuable. "Yes, so", "so accepted," "so right,"

\footnotetext{
${ }^{26}$ Arictotel. Cochynenyia v chetyrex tomax. - Tom 1: Metafyzyka / red. V. F. Acmyc. - Mockva : Mycl, 1975. $-550 \mathrm{c}$.
} 
"so appropriate". he beginning of the destruction of the median canonical filter begins in the Renaissance epoxy. People began to become interested in the fact that the objective reality was not about themselves. The objects of work are perceived as things that are not capable of being transmitted by nature itself. There is an idea that a person may not match the sample but create the sample. Yes, God has touched man, faith is knowledge, divine will - the laws of the New Hour science. Renaissance - these are the assertions of new values: individual liberties, threefold, initiatives. It asserts the human right to the transformation of the world, to the enjoyment of authorship ${ }^{27}$.

The destruction of the canon begins from the moment when a person begins to look at nature, removed as a painter, who paints paintings, on his own. New cognitive attitude of the person to the world arises when the person finds "It is possible to come out of the world, if it has become one, to go outside, in order to view this world without you, in that form, which is not purified by its adherence" 28 . The creation of the "picture of the world" is the first stage in the formation of direct technological culture. It is necessary to understand clearly that the right is always implicitly implicit, in the latent state. The project turns out to be, so to speak, fused with a valid substantive transformation ${ }^{29}$. With the appearance of perspective painting, the appearance of a person in the outer world originates from its subjective phenomenon and thus eliminates from the person, the objectivity in the image. Therefore, the manifestation of a person can be translated into the plan of material manifestation and alone in this semiotic plan can be consideration, correction, imprisonment, at one and the same time, the framework of this entirety were clearly divorced programs of scientific theoretical and subject practical practice. Cognition at this distinction as one's gaze, and the theoretical pursuit were reduced to the universal harmony of the harmonious being real. In the substantive and practical activity, the medieval tradition rigorously identified the notion of

\footnotetext{
${ }^{27}$ Locev A. F. E'ctetika Vozrozhdeniya. - Mockva : Ickycctvo, 1978. - 495 c.

${ }^{28}$ Axytin A. V. Ponyatie "priroda" v antichnocti i v Novoe vremya. - Mockva : Nayka, 1988. - 208 c.

29 Kolmogorova L. C. Vozractny'e vozmozhnocti i ocobennocti ctanovleniya pcixologicheckoj kyl'tyry' shkol'nikov : dicc. ... d-ra pcixol. nayk. - Mockva, 2002. - 425 c.
} 
"know" and "be able to do". In this activity, the question is "how to do?" And there is no room for the question "why?".

Researchers point out certain object features of the canon of domainspecific (rhemic) activity ${ }^{30}$. Let us precede this recipe, expressed in a short description of the types "take", "stock", "measure", "endure". The recipe is not a project of practical activity, but a canonical model of activity, a projection of magical knowledge. There is point for doubt in it. The truth is one, it is augmented by the commonalities of mankind, anchored in the canon. The recipe is an element of mythological thinking, and "the myth was not knowledge but life, it was not studied, but in it we lived, in it (or by it) we were misled"31. The canyon is also inextricably linked to the recipe. Any recipe is a sacrilege, a mystery, some intrinsic value. This target is sacral, sacred, and is not subject to analysis, parsing, that is, only possible to follow and to follow. This is precisely related to the automaticity of execution. Receptive knowledge was stored in the smallest detail and then in the exact, according to the given "scenario", was opened. The script left no room for reflection. The very idea of the reflection is alien to the canon. It was perceived as a sin, an apostasy, she caused social sanctions, this dislike, for her. Finally, the canon is a distinctive sign system in which the recipe is coded and its rules, norms, and prohibitions associated with it. But this system is dogmatic, and only one value is assigned to it. Such a language can only be answered with certain specific questions, but in no case should it be asked new ones with the subject itself. Speaking at the origin of the projection, the students emphasize that the first projectors were "engineers-engineers",32, but "the picture reveals the nature",33.

\footnotetext{
${ }^{30}$ Goroxov V. G. Znat', chtoby' delat'. Ictoriya inzhenernoj profeccii i ee rol' v covremennoj kyl'tyre. Mockva : Znanie, 1987. - 176 c.; Gycev C. C., Gyceva E. A.»Vzaimodejctvie poznavatel'ny'x proczeccov v naychnom i texnicheckom tvorchectve. - Leningrad : Nayka, 1989. - 128 c.; Rozin V. M. Cpeczifika i formirovanie ectectvenny'x, texnicheckix i gymanitarny'x nayk. - Kracnoyarck : Izd-vo Kracnoyarckogo yn-ta, 1989. - 200 c.; Kharitonovich D. E'. Izobretatel'ctvo i rannie formy' inzhenernoj deyatel'nocti // Voprocy' filocofii. -1985 . - № 2. - C. 91-102.

${ }^{31}$ Kharitonovich D. E'. Izobretatel'ctvo i rannie formy' inzhenernoj deyatel'nocti // Voprocy' filocofii. 1985. - № 2. - C. 91-102.

${ }^{32}$ Goroxov V. G. Znat', chtoby' delat'. Ictoriya inzhenernoj profeccii i ee rol' v covremennoj kyl'tyre. Mockva : Znanie, 1987. - $176 \mathrm{c}$.

${ }^{33}$ Axytin A. V. Ponyatie "priroda" v antichnocti i v Novoe vremya. - Mockva : Nayka, 1988. - 208 c.
} 
The overcoming of the canon begins, when dismemberment is active, that is, the reflection of the separation and the information of the manufacturer of the same image produced. First of all, such distinctions are made with the period before the mass replication of these or other actions, which are significant in terms of their social results. The product of such action is significant in itself, is removed from the contact of the canon, and leaves its precious sacralized area, it loses its "creative individuality", including "neutral in valuable material production" 34 . Insofar as only the substantive-perforating activity (in a wide variety) becomes a mass, even if the value of this activity can be "excused by the barrel", they appear as a precursor for transferring the attention from the value of this activity to its technology $y^{35}$. In the case of technogenic approach, in the center of gravity, the axiom of the object-conversion activity is determined as the activity of the active. In the neutral medium of material production, various transformations of the filtered sample, which were previously neglected in the can, are possible. These transformations are based on the same line: change of technology (change of recipe), change of designation, touching and squeezing the skin tight, preserving only the traditional form of the activity of activity, which is a necessary for successful social and cultural activity. Texting leads to the delimitation of the functions of an earlier single activity entity. In the process of disaggregation in the operation, the activity of the entity is further reduced to the interaction of the generalized forces and factors. There is a similar methodological characterization characteristic of the technical sciences, in which the main is the knowledge of all their subjective-conversion activities.

From the moment of excision, the technologic approach as a means of elevation of the preoccupation of the object-conversion activity. Accordingly, there are also means of projecting. The most ancient can be considered: the present equivalence or economic projection, the organizational projection and the technical projection. An economic

\footnotetext{
${ }^{34}$ «Khill P. Nayka i ickycctvo proektirovaniya: metody’ proektirovaniya, naychnoe obocnovanie reshenij. Mockva : Mir, 1973. - 264 c.

${ }^{35}$ Khill P. Nayka i ickycctvo proektirovaniya: metody' proektirovaniya, naychnoe obocnovanie reshenij. Mockva : Mir, 1973. - 264 c.
} 
projection arises in connection with the necessity to anticipate the effective purpose of a substantive-conversion activity, to prevent costs and benefits $^{36}$. Organizational projecting has to do with the necessity of resolving the magnitudes; the initial priority is a momentary and technical problem, until the decision is made as to the large number of contractors whose forces should be directly directed. In the further development of production, there is a need for the distribution and coordination of production facilities, and also the integration, the integration of the former, the production, if there were also problems with organizational design. It can be said that the class-lesson system is a technological solution to the problem of organizing projection. Finally, the techno- logical projection gives it the power of saving the form and the underlying relationship (morphology) of the project, to consider variants of models of technology with the view of their effects, speeds of production, simplicity and others.

At the stage of excision, the projection as self-activity emerges and the specific - cymotic (signs) - means of this activity. In the midst of these tools, a distinctive role of the drawing, perspective painting, is distinguished.

The method of visualizing a problem, changing its vision is the old method of projecting. A. B. Ахутін points to the double role of the picture as a mediator between the man and the object of his activity. From one side, the painting seems to yank out people from the world and give them the ability to analytically dissect the depth plates. In this case, everything must be real, visible on the plane. Secondly, the picture replaces ambiguous words when the human phenomena are objectified.

In this way, the first phase of the appearance of a direct-technographic filter, its separation from the canonical flax became a techno- logical phase. In the center of attention, the substantive structures of practice are terminated, and, accordingly, the activity of their development and organization is determined. Traditional understanding of a project, if it was earlier in the text, in the case of other things, is a cyclical document for the

\footnotetext{
${ }^{36}$ Cheshev V. V. Vzaimocvyaz' inzhenernoj deyatel'nocti i naychnogo znaniya // Voprocy' filocofii. 1986. - № 3. - C. 53-60.
} 
creation of any kind of objects ${ }^{37}$. At the change came the modern understanding of the project as a complete cycle of the projective activity: the individual, the team, the organization, the company and the company. Every project from the emergence of an idea to the fullest completion brings about a number of stages of its own development. Complete cycles of development stages represent the life cycle of the project. It is customary to divide the life cycle into phases, phases into stages, and stages into stages.

It is natural that any project realizes a certain cyclicality of technologies. The most important role in the organization of a proactive activity is played by reflection - a thorough analysis of the goals, tasks of the project, results, etc.

In this way, the beginning of the formation of direct-technological filters of the future will be read by the technologists and can be won in the $\log$ of the category of the project on the basis of the triplet of the phases of the project: the projecting phase, the technological phase, the reflection phase. From this position, we hold on to our research, and we will consider the relevant phases in the course of practical activity. Understandably, such a division is quite common.

Concepts for the text-to-text filter are the key concepts: text, text, and reflection. In this case, two of them are seemingly opposite: the project (long - closed forward) and the reflection (long - reversed).

For any practical activity, the first phase - projecting - will have the same concepts and principles. Although it is understandable that in each of the specific cases, depending on the profession, there is a possibility for the activity, the opportunity to have the quality of the worker is possible.

The logic of the second phase - the technologic - it is determined by the content of each specific practical activity, which is determined exactly by the by a unique facsimile every now and then in totally different sets of conditions.

\footnotetext{
${ }^{37}$ Novikov A. M., Novikov D. A. Metodologiya. - Mockva : CINTEG, 2007. - 668 c.
} 
The third phase - the reflection phase - as well as the projection phase, is unambiguous and can be described in a unified way for any practical activity of the concept and structure.

The processes develop by the help of the creation of such a structure, in which the known mutual interactions are again realized with greater efficiency and interoperability. There is a technological thinking associated with the division of the operations inside the whole, their standardization and repetition. Adequate language translation is appeared. At the same time, the whole canon is being disturbed. It develops a polarity of rational and valuable aspects in the project.

On the textual phase of the canyon's distortion, the directtechnological thinking leaves behind the usual images of objects, fixed sets of standard shapes ${ }^{38}$. The author's use as a valuable word of directtechnology lies in the technological innovation. The object of the projection is to identify, in the first place, all the ways of creation determine the traditional objects. However, with the development of these means, the expansion of the world of artifacts, a person's right view is more and more imprinted, and an image of an object, their morphology and end. There is a variety of subjects that do not go beyond accepting functional relationships.

The contractive phase as a continuous phase of canyon distortion is even greater than the gap between the sensory and the precipitating sites. Creating a form leads to the creation of a rich second nature, farther from the natural. In this second nature, one has its own relations and laws, giving birth to new human needs, far from natural, one's own aesthetics. However, traditional types of functions will still be preserved. In this phase, the practical as a way of human endeavor enriched with new methods of direct-techno logical thinking, various modeling methods, different methods of refining, endpointing, etc.

During this period, the state of formation of the methodological methodology is reflected, which has fixed the rational aspect of the

\footnotetext{
${ }^{38}$ Gycev C. C., Gyceva E. A. Vzaimodejctvie poznavatel'ny'x proczeccov v naychnom i texnicheckom tvorchectve. - Leningrad : Nayka, 1989. -128 c.
} 
projection. It is revealed that the causal description of the phenomena is the only knowledge in the natural-natural way of understanding - it is not the only object of the intellectual activity of man. No less important and valuable concept of intellectual activity may be knowledge in its pure form, but prescriptive. Knowledge and requirements also require a variety of evaluation criteria. For the sake of knowledge, this is "truth - not true." The prescripts also evaluate the preceding measure as they correspond to the given task and the final results, and the results, also, they can be scattered by the parameters of optimality, economy and the like. From this historical stage, the differentiation of cyclic needs for knowledge and prescription begins.

For science and methodology, questions arise about community and differentiation of study and projection, about their valuable cooperation, and about their interaction. Historical announcements of the stages of occurrence of projection are denoted in the annulus by the largest and most common ones. At the early stage of the formation of direct-technocultural filters, the deletion of rectification as a separate activity constitutes a definite approach to this activity, which is traditional ${ }^{39}$.

Historically, it is the traditional approach that is focused on the object of projection. In this case, the self-priming projections are less wellknown. According to the traditional approach, the rigorous manifestation is without any changes in the projection technology. The magnitude of such a large number is determined by the number of variants of the projected objects. The projection technologies themselves, in this case, flash invisibly from the respective projection objects, which "derive" from the specifics of these objects.

The three-way approach leads to the case of the set of residuals - the closed set of the sequences of the formation of the second one to the second one. The one-sided attribution of the classical project is one-dimensional, one-and-a-half determinism of classical Newtonian mechanics. The ideal of classical learning - the ideal of cyber-objectivity - is a reflection in traditional design as well. A clear separation of the created object, from one side, and the

\footnotetext{
$172 \mathrm{c}$.

${ }^{39}$ Gacparckij V. Prakceologicheckij analiz proektno-konctryktorckix razrabotok. - Mockva : Mir, 1978. -
} 
adjusting, milling, forming object, from the other - is a very bright line. This type of design results in a thorough deletion of the projection of the all of the projectors, the refusal of reflection is only the beginning of the projection, the unambiguous nature of the precepts ${ }^{40}$.

Traditional projection was a successful development until that moment, until the existing type prototype was exhausted.

Effectively, for the traditional approach, it is only possible to project a specific one: the subject, principle, structure - whose functions are known (in each case, the common word), and therefore the created objects "fit" in the corresponding cells. The traditional projection is in line with the "further development" strategy. It is effective for the realization and concretization of well-known goals.

The (traditional) projection was viewed as isolated, delimited by the creation of the object that was suspended; that is, it was such that it did not emerge beyond the creation of objects, projections, structures, and with the above given functional characteristics. But if any pragmatic decision should be considered not isolated, not by itself, but as a link of possible future, directed to the future, it is lost. An unconventional project is always a complex task, the solution of which is impossible without taking into consideration a social and cultural context of this problem. Changing the functions of any system is obligatory, in principle it affects the performance in the method. (Unfortunately, changes in metasystem can be undetected, have a controllable character, and do not appear to accumulate a critical level of these changes. This creates the illusion of the possibility of an isolated solution of the problem with a problem in a subsystem, but early or late a critical level of change can be reached and reflected. Illusory isolation of the right tasks and, accordingly, the approach to them on the basis of the traditional projection is threatened by grave consequences). The basic complex approach of a simple task of unconventional projecting determines the new style of a straightforward technological activity, in which one and the same social, cultural, technical and organizational constituents interact and complement each other.

\footnotetext{
${ }^{40}$ Born M. Fizika v zhizni moego pokoleniya. - Mockva : Izd-vo inoctrannoj literatyry’, 1963. - 535 c.
} 
Accordingly, when the projections are formed, there is a non-nominal interaction of the states and approaches of different ways, their mutual enrichment and complementarity. The projection appears as a distinctive sphere of the cultural-historic creativity, where the "information about the world transforms itself into the following future activities ${ }^{41}$. It is fundamentally important that while considering the specific features of another object or entity, and concentrating on the internal law of direct and technical activity without direct specific character of the object being projected. There are many literatures, where such a framework is described by problems of non-conventional design ${ }^{42}$. Dzh. K. Dzhonc goes a long way in affirming the cynicism of his position, when he clarifies that the methods of projection are intended for the projection of anything, for the development of all citation in general, having on the basis of function and the use of things, the system in which they enter, or the centers in which they function $^{43}$. The analysis of the literature gives an opportunity to conclude that, until the 20th century of the century of projection, it is identified as an independent co-culture phenomenon. Precise-technological activity of the constituent as an individual, very limited and characteristic not only in engineering and business, but also in non-traditional galaxies, where its objects are both words and new objects, information centers, systems of activity. In this way, a straightforward technological culture that has emerged from a fractured canonical culture, appealed to the nonarticulated whole and the canopy of the canon of freedom, the authorship, the reflexive text, gradually came to the idea and methods of unconventional projection as a new level of reunion.

Concepts for the text-to-text filter are the key concepts: text, text, and reflection. In this case, two of them are seemingly opposite: the project (long - closed forward) and the reflection (long - reversed).

\footnotetext{
${ }^{41}$ Gycev C. C., Gyceva E. A. Vzaimodejctvie poznavatel'ny’x proczeccov v naychnom i texnicheckom tvorchectve. - Leningrad : Nayka, 1989. - $128 \mathrm{c}$.

${ }^{42}$ Gacparckij V. Prakceologicheckij analiz proektno-konctryktorckix razrabotok. - Mockva : Mir, 1978. 172 c.; Dzhonc Dzh. K. Metody’ proektirovaniya ; per. c angl. - Mockva : Mir, 1986. - 32 c.; Ditrix Ya. Proektirovanie i konctryirovanie. Cictemny'j podxod / Ya. Ditrix. - Mockva : Mir, 1981. - 456 c.; Keccidi F. X. Ot mira k logocy / F. X. Keccidi. - Mockva : My'cl', 1972. - 198 c.; Khill P. Nayka i ickycctvo proektirovaniya: metody' proektirovaniya, naychnoe obocnovanie reshenij. - Mockva : Mir, 1973. - $264 \mathrm{c}$.

${ }^{43}$ Dzhonc Dzh. K. Metody' proektirovaniya ; per. c angl. - Mockva : Mir, 1986. - 32 c.
} 
Thus, V.F. Cidorenko ${ }^{44}$ states as the genesis of a practicallytechnologically dedicated gene indicates that it is an intrinsically practically-technologically correct, if it is a present-day complex organized system of interaction of different facsimiles, functionally connected with the systems of management, planning and production, and, first, if it is a special kind of production of a fair documentation, in the language which is expected and desirable for the realization of the image of the future object - things that are notable areas, systems of activity and life.

\section{CONCLUSIONS}

But the direct-textual filter does not reduce itself only to an intrinsic direct-textual activity, and another source, K. М. Кантор, ${ }^{45}$ introducing detached practically-productive activity, if it is implemented in the true language of the boundary posterior and the value of the filter.

In this way, the relationship of projection with science, philosophy, coloring, art, technology, production, living, government and other social institutions and functional systems of activity must be deduced from the understanding of the fundamental cultural state of projection, its innovation, and cultural nature. In the sphere of coloring, the need for this potential and, as a result, the inclusion of direct-textured filters are the most important results for coloring, in our opinion, with the fact that the gradual extrusion of a nay-technocratic paradigm, a valuable-selfdetermination of the educators of a different priority of the humanitarian paradigm served a new estimate of the color of the octane, which would be responsible for the social ordering and needs of the occipital origin. The problem of forming a direct-technoculture is actual for a system of technological evaluation, as it is, basically, progressive meets the need for the formation of a new quality of human XXI century. - is life-giving and practically-oriented, culturally responsive and promotes the formation of social competency of objects of manifestation. In such a context, the direct-techno-logy can be defined as "socially-friendly, three-prong

\footnotetext{
${ }_{44}^{44}$ Cidorenko V. F. Genezic proektnoj kyl’tyry’ // Voprocy’ filocofii. - 1984. - № 10. - C. 86-99.

${ }^{45}$ Kantor K. M. Proektnoct' rycckoj kyl'tyry'. - Mockva, 1980. - 267 c.
} 
activity if at this there is a dialectical unity of the predetermination of priming (the formation of values, the norm, the sign system, etc.) and the decomposition (the estimation), aiming at the transformation of activity, which is the outlying point of view, to the transformation of the wealth of humanity into the inner wealth, or the secular detection and development of cynical forces, as it takes more and more of the projection of the objects.

Formation of a direct-technographic filter in such a comprehensible principle is impracticable without a valuable-aiming self-definition in humanitarian paradigm, insofar as it is recognized in its context as valid, it constitutes value propositions for the self-determination of any subject of pedagogical origin. And if in the result of paradigmatic self-determination in the context of the humanitarian paradigm, we will understand the point of manifestation as the process of person development in the shade of its formation, that the formation of a direct-technography, together with the traditional training, plays cytology in this process.

\section{REFERENCES}

1. Acmolov A. G. Pcixologiya lichnocti. - Mockva : MGU, 1980. $367 \mathrm{c}$.

2. America 2000: an Education Strategy. - V. S. Government printing office, 1991. $-66 \mathrm{p}$.

3. Arictotel. Cochynenyia v chetyrex tomax. - Tom 1: Metafyzyka / red. V. F. Acmyc. - Mockva : Mycl, 1975. - 550 c.

4. Arnoldov A. Y. Teoryia kyltyry: Yctoryzm y voprocy metodolohyy // Kyltyra, chelovek y kartyna myra. - Mockva : Nayka, 1987. - C. 5-27.

5. Axytin A. V. Ponyatie "priroda" v antichnocti i v Novoe vremya. Mockva : Nayka, 1988. - 208 c.

6. Ball G. A. Teoriya ychebny'x zadach. - Mockva : Pedagogika, 1990. $-184 \mathrm{c}$.

7. Bereziuk O.S. Metodyka poetapnoho upravlinnia protsesom modeliuvannia pedahohichnykh sytuatsii // Profesiina pedahohichna osvita: innovatsiini tekhnolohii ta metodyky: Monohrafiia / $\mathrm{Za}$ red. 
O. A. Dubaseniuk. - Zhytomyr : Vyd-vo ZhDU im. I. Franka, 2009. S. 377-390.

8. Born M. Fizika v zhizni moego pokoleniya. - Mockva : Izd-vo inoctrannoj literatyry', 1963. $-535 \mathrm{c}$.

9. Caimon H. Nayky ob yckycctvennom. - Mockva : Myr, 1972. $-147 \mathrm{c}$.

10. Cemenova N. N. Nayka kak yavlenye kyltyry // Nayka y ee mecto v kyltyre. - Novocybyrck : Nayka, Cyb. otdelenye, 1990. - C. 51-58.

11. Cerykov V. V. Obrazovanye y lychnoct. Teoryia y praktyka proektyrovanyia pedahohycheckyx cyctem. - Mockva : Lohoc, 1999. $-272 \mathrm{c}$.

12. Cheshev V. V. Vzaimocvyaz' inzhenernoj deyatel'nocti i naychnogo znaniya // Voprocy' filocofii. - 1986. - № 3. - C. 53-60.

13. Cidorenko V. F. Genezic proektnoj kyl'tyry' // Voprocy' filocofii. - 1984. - № 10. - C. 86-99.

14. Clactenyn V. A., Podymova L. C. Pedahohyka: Ynnovatsyonnaia deiatelnoct. - Mockva : Mahyctr, 1997. - C. 36.

15. Cydorenko V. F. Henezyc proektnoi kyltyry // Voprocy fylocofyy. -1984 . - № 10. - C. 86-99.

16. Ditrix Ya. Proektirovanie i konctryirovanie. Cictemny'j podxod. Mockva : Mir, 1981. $-456 \mathrm{c}$.

17. Dzhonc Dzh. K. Metody' proektirovaniya ; per. c angl. - Mockva : Mir, 1986. $-32 \mathrm{c}$.

18. Ekolohyia cheloveka: ocnovnye problemy. Cbornyk naychnyx trydov. - Mockva : Nayka, 1988. - 222 c.

19. Frydman L. M. Pedahohycheckyi opyt hlazamy pcyxoloha. Mockva : Procveshchenye, 1987. - 224 c.

20. Gacparckij V. Prakceologicheckij analiz proektno-konctryktorckix razrabotok. - Mockva : Mir, 1978. - $172 \mathrm{c}$.

21. Gineczinckij V. I. Ocnovy' teoreticheckoj pedagogiki : ychebnoe pocobie. $-\mathrm{CPb}$., 1992. $-325 \mathrm{c}$.

22. Goroxov V. G. Znat', chtoby' delat'. Ictoriya inzhenernoj profeccii i ee rol' v covremennoj kyl'tyre. - Mockva : Znanie, 1987. - $176 \mathrm{c}$. 
23. Gycev C. C., Gyceva E. A. Vzaimodejctvie poznavatel'ny'x proczeccov v naychnom i texnicheckom tvorchectve. - Leningrad : Nayka, 1989. - 128 c.;

24. Hershynckyi B. C. Fylocofyia obrazovanyia dlia XXI veka: (V poyckax praktyko-oryentyrovannyx obrazovatelnyx kontseptsyi. Mockva : Covershenctvo, 1998. - 608 c.

25. Hershynckyi B. C. Fylocofyia obrazovanyia: naychnyi ctatyc y zadachy // Covetckaia pedahohyka. - 1991. - № 4. - C. 69-74;

26. Holocovker Ya. Э. Lohyka myra. - Mockva : Nayka, 1987. - 218 c.

27. Kantor K. M. Opyt cotsyalno-fylocofckoho obiacnenyia proektnyx vozmozhnoctei dyzaina // Voprocy fylocofyy. - 1981. - № 11. - C. 84-97.

28. Kantor K. M. Proektnoct' rycckoj kyl'tyry'. - Mockva, 1980. $267 \mathrm{c}$.

29. Keccidi F. X. Ot mira k logocy. - Mockva : My'cl', 1972. - 198 c.

30. Kharitonovich D. E'. Izobretatel'ctvo i rannie formy' inzhenernoj deyatel'nocti // Voprocy' filocofii. - 1985. - № 2. - C. 91-102.

31. Khill P. Nayka i ickycctvo proektirovaniya: metody' proektirovaniya, naychnoe obocnovanie reshenij. - Mockva : Mir, 1973. $264 \mathrm{c}$.

32. Khiucen T. Obrazovanye v 2000-m hody: yccledovatelckyi proekt ; per. co shved. E. M. Cokolova. - Mockva : Prohrecc, 1977. - 343 c.

33. Kolmogorova L. C. Vozractny'e vozmozhnocti i ocobennocti ctanovleniya pcixologicheckoj kyl'tyry' shkol'nikov : dicc. ... d-ra pcixol. nayk. - Mockva, 2002. - 425 c.

34. Kyliutkyn Yu. N., Cyxobckaia H. C. Modelyrovanye pedahohycheckyx cytyatsyi. - Mockva : Pedahohyka, 1981. - 207 c.

35. Kyzmyna N. V. Ocherky pcyxolohyy tryda ychytelia: pcyxolohycheckaia ctryktyra deiatelnocty ychytelia y formyrovanye eho lychnocty. - Lenynhrad : LHU, 1967. - 184 c.

36. Kyzmyna N. V., Hynetsynckyi V. Y. Aktyalnye problemy profeccyonalno-pedahohycheckoi podhotovky ychytelia // Covetckaia pedahohyka. - 1982. - № 3. - C. 63-66. 
37. Locev A. F. E'ctetika Vozrozhdeniya. - Mockva : Ickycctvo, 1978. - 495 c.

38. Novikov A. M., Novikov D. A. Metodologiya. - Mockva : CINTEG, 2007. $-668 \mathrm{c}$.

39. Nychkalo N.H. Rozvytok profesiinoi osvity $\mathrm{v}$ umovakh hlobalizatsiinykh ta intehratsiinykh protsesiv: monohrafiia. - K.: Vydavnytstvo NPU imeni M.P. Drahomanova, 2014. - $125 \mathrm{~s}$.

40. Nykytyn V. A. Orhanyzatsyonnye typy covremennoi kyltyry : avtoreferat doktora kyltyrolohyy : 24.00.01 - teoryia kyltyry. - Toliaty Mockva, 1998. - 49 c.

41. Onyshkyn V. H., Kyliutkyn Yu. N. Nepreryvnoe obrazovanye pryorytetnoe napravlenye nayky // Covetckaia pedahohyka. - 1989. № 2. - C. 86-91.

42. Rozin V. M. Cpeczifika i formirovanie ectectvenny'x, texnicheckix i gymanitarny'x nayk. - Kracnoyarck : Izd-vo Kracnoyarckogo yn-ta, 1989. - 200 c.

43.Zahviazynckyi V. Y. Pedahohycheckoe tvorchectvo ychytelia. Mockva : Pedahohyka, 1987. - $160 \mathrm{c}$.

44. ЮНЕСКО и развитие образования взрослух // Перспектива. Вопросу образования. - 1982. - № 1-2. - С. 137-145.

\section{Information about the authors:} Slabko V. M.,

Doctor of Pedagogical Sciences, Head of the Department of Adult Education at the Faculty National Pedagogical Dragomanov University 9, Pyrohova str., 01601, Kyiv, Ukraine

Makarenko L. L.,

Doctor of Pedagogical Sciences, Professor, Professor of Department of the Informative Systems and Technologies National Pedagogical Dragomanov University 9, Pyrohova str., 01601, Kyiv, Ukraine 
Publishing house "Liha-Pres"

9 Kastelivka str., Lviv, 79012, Ukraine 44 Lubicka str., Toruń, 87-100, Poland

Printed by the publishing house "Liha-Pres"

Passed for printing: September 17, 2019.

A run of 150 copies. 